
ISSN: 1666-3055

Perspectivas Metodológicas forma parte del Portal de Revistas Científicas de la UNLa, "Arturo Peña Lillo", a través del cual se puede acceder a su publicación digital.

() Los autores

(c) Ediciones de la UNLa / 2017

29 de setiembre 3901

Remedios de Escalada - Partido de Lanús

Pcia. de Buenos Aires - Argentina

Tel. +54 11 5533-5600 int. 5686 


\section{Perspectivas Metodológicas}




\section{Perspectivas Metodológicas}

ISSN 1666-3055 / Año 17 / Nro. 20 / noviembre de 2017

Publicación semestral del Departamento de Humanidades y Artes de la Universidad Nacional de Lanús

Universidad Nacional de Lanús

Rectora

Ana Jaramillo

Vicerrector

Nerio Neirotti

Departamento

de Humanidades y Artes

Director

Daniel Bozzani

Comité Editorial

Ana Farber

Héctor Muzzopappa

Oscar Tangelson

Hugo Spinelli
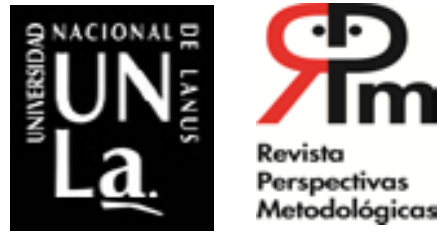

Revista

Perspectivas

Metodológicas

Servicio de indización/service:

EBSCO;

Latindex Sistema Regional de

Información en Línea para Revistas

Científicas de AméricaLatina,

El Caribe, Espańa y Portugal

CAICYT - CONICET;

Red Latinoamericana de Revistas (Flacso, Argentina) http://flacso.org. ar/latinrev/;

Edición digital http://revistas.unla. edu.ar/epistemologia del Portal de

Revistas Científicas de la UNLa

"Arturo Peña Lillo" bajo Open

Journal Systems.
Staff de la Revista

Directora

Cristina Ambrosini

Editor Responsable

Andrés Mombrú Ruggiero

Comité Editorial

Cristina Ambrosini

Andrés Mombrú Ruggiero

Pablo Martín Méndez

Cecilia Pourrieux

Traducciones

Claudia Bértolo

Comité Asesor

Javier Echeverría

(Universidad Complutense de Madrid)

Ricardo Gómez

California State University)

Manuel Barrios Casares

(Universidad de Sevilla - España)

Massimo Desiato

(Universidad Católica Andrés Bello -

Venezuela)

Julio De Zan

(Universidad Nacional de Entre Rios)

Alfonso Galindo Hervás

(Universidad de Murcia- España)

Daniel Dei

(Universidad Nacional de Lanús)

Mónica Cragnolini

(Universidad de Buenos Aires)

Rodrigo de Paiva Duarte

(Universidad Federal de Minas Gerais Brasil)

Roxana Ynoub(Universidad de Buenos Aires (Universidad Nacional de Lanús)

(C) Ediciones de la UNLa

29 de Septiembre 3901 - Remedios de Escalada

Provincia de Buenos Aires - Argentina

Tel.: 5533-5600, int. 5686

Email: metodologia@unla.edu.ar - Sitio web: www.unla.edu.ar 


\section{Índice}

Editorial

\section{Artículos}

La epistemología histórica en perspectiva. Bachelard en la epistemología francesa

Naim Garnica

Las politicas educativas en la Historia de la Educación

Un aporte para el estudio de las políticas educativas, en el Centenario de la Revolución Argentina

Laura S. Guic

Ciencia económica y valores. Riquezas y Fortunas

Diego Guichón

\section{Perspectivas}

Cómo juntar el agua y el aceite: metodología cientifica y hermenéutica según Roxana Ynoub Cristina Ambrosini . .57

Modos descentrados de autoría en la era de la web participativa y social: el impacto de los nuevos medios en la producción y circulación de conocimiento académico

Mariana Ferrarelli

La importancia de la interculturalidad en la clase de lengua extranjera

Mariana Elisa Castillo /María Julia Pourrieux 77

\section{Dossier}

Presentación

Cristina Ambrosini, Cecilia Pourrieux

E pur si riscaldato ( $Y$ sin embargo se calienta)

Una aproximación a la ética profesional en el uso de los recursos naturales

José Luis González

Responsabilidad social en la gestión de la energía: el papel del Estado y de los funcionarios públicos involucrados. A propósito del aumento de las tarifas de gas natural. Su repercusión María de los Angeles Roveda /Matías Toso 99 
Población ocupada, problemas de empleo, y condiciones de vida en Catamarca y Tucumán (1880-1970)

Ariel Osatinsky

\section{Reseñas}

PHILIP KITCHER, Avance de la Ciencia. Ciencia sin ley, Objetividad sin Ilusiones. México, UNAM, 2001

Gabriel Paravano / Diego Muñoz 137

MARÍA GABRIELA PAULI, "La Cabeza piensa y ordena y los brazos ejecutan...". Representaciones sociales de la élite santafesina a comienzos del siglo XX, Universidad Católica de Santa Fe, Santa Fe, 2017

Facundo Di Vincenzo

JEAN YVES MOLLIER, La Lectura y sus públicos en la edad contemporánea, Buenos Aires, Ampersand, 2013

Facundo Di Vincenzo 141

CRISTINA CAMPAGNA, MÓNICA GIARDINA, OSCAR CUERVO, EDUARDO LASO, Para pensar la ciencia y la técnica. Una introducción a la tecnociencia, Buenos Aires, Editorial FEDUN, 2017

Cecilia Pourrieux... 


\section{Editorial}

La publicación actual de Perspectivas Metodológicas corresponde al último número de un año complejo e inmerso en una etapa significativa. Sin entrar en detalles de la realidad inmediata, basta observar que el 2017 tuvo aniversarios de hechos por demás contradictorios. Sólo por citar algunos ejemplos: se cumplieron 150 años del nacimiento de Marie Curie, 100 años de la Revolución Rusa, 50 años del primer trasplante de corazón, 50 años del asesinato de Ernesto "Che" Guevara o 40 años de la muerte de Rodolfo Walsh, de quien podríamos utilizar con justicia la frase: "La realidad no es sólo apasionante, es casi incontable". Pero la complejidad mencionada, a quienes integramos este cuerpo editorial, antes que sumergirnos en una parálisis, nos impele con más fuerza a interpelar la realidad, ¿Cuáles son los límites del trabajo intelectual? ¿Hacia dónde se dirige el país? ¿En qué condiciones se desenvolverá el mundo del trabajo y la reflexión? Si consideramos que aún el saber científico más puro, carece de neutralidad, no vamos a otorgarle a cualquier formulación teórica esa cualidad que por otra parte no reivindicamos. Damos por descontado que las respuestas a estas preguntas no son neutrales y está muy bien que así sea.

En la historia del pensamiento, una concepción conservadora de la filosofía considera que el valor del intelectual es el de "tomar distancia de la realidad" para poder analizarla con mayor "objetividad", cómodamente apoltronado en una torre de cristal. Por el contrario, desde esta perspectiva, es difícil creer que una teoría sea neutral porque además de que está asentada sobre condiciones históricas imposibles de obviar, son enunciadas con la función de promover una transformación de un estado de cosas. Por eso, el trabajador intelectual no es aquel que toma una distancia aséptica, sino el que se zambulle en la realidad. De ahí el valor de esta revista.

En este número veremos los siguientes artículos: "La epistemología histórica en perspectiva. Bachelard en la epistemología francesa" de Naim Garnica (Universidad de Catamarca), donde se reconstruyen algunas interpretaciones sobre la epistemología francesa destacando las características específicas de esa perspectiva. Por otro lado, el artículo de Laura Guic (Universidad Nacional de Lanús) "Las políticas educativas en la Historia de la Educación. Un aporte para el estudio de las políticas educativas, en el Centenario de la Revolución Argentina” presenta avances en la investigación de la política educativa de principios de siglo XX, centrándose en las acciones del Consejo Nacional de Educación en Argentina por los festejos del Centenario (1910). Finalmente, en esta sección, Diego Guichón, con el trabajo "Ciencia económica y valores. Riquezas y fortunas", investiga, desde el campo de la economía, los mecanismos mediante los cuales los valores no epistémicos influyen sobre el contenido de la disciplina considerada como ciencia o economía positiva. 
Para la sección "Perspectivas", Cristina Ambrosini escribe: "Cómo juntar el agua y el aceite: metodología científica y hermenéutica", mostrando el modo en que el enfoque dialéctico propuesto por Roxana Ynoub en dos de sus obras (2012 y 2014), es el resultado de la experiencia sostenida en el dictado de cursos de grado y de posgrado en diversas carreras de formaciones científicas y profesionales que representan verdaderos desafíos al planeamiento de la investigación. La segunda Perspectiva titulada "Modos descentrados de autoría en la era de la web participativa y social: el impacto de los nuevos medios en la producción y circulación de conocimiento académico", pertenece a Mariana Ferrarelli, quién, en el contexto del Proyecto de Investigación Amilcar Herrera 2015 "El concepto de autoría y sus implicancias éticas. Las normativas vigentes, imaginarios y conflictos de interés en la universidad argentina" (Centro de Investigaciones en Teorías y Prácticas Científicas, UNLa, Director: Dr. Andrés Mombrú), presenta un análisis exhaustivo de los nuevos contextos que generan Internet, las redes sociales y los nuevos medios de producción y circulación del conocimiento científico en relación con el concepto de autoría y sus formas tradicionales. La tercera Perspectiva "La importancia de la interculturalidad en la clase de lengua extranjera”, elaborada por Mariana Castillo y María Julia Pourrieux, toma como eje el aspecto intercultural en la clase de Francés Lengua Extranjera para presentar un proyecto áulico donde se utiliza al francés en una situación real de comunicación. El objetivo final será el de priorizar la cultura materna, en contraposición a la mayoría de los manuales que presentan sus textos desde una visión etnocentrista de los aspectos culturales, favoreciendo particularmente la cultura francesa.

El Dossier de la Revista contiene tres artículos que tienen como eje el siguiente tema: "Las sociedades tecnocientíficas y sus implicancias económicas y sociales". El artículo de José Luis González "E pur si riscaldato (Y sin embargo se calienta) Una aproximación a la ética profesional en el uso de los recursos naturales", es un trabajo donde aparece un concepto compensatorio o protésico para ser tomado en cuenta por gerenciadores de empresas públicas y privadas del sector energético. El artículo de María de los Ángeles Roveda y Matías Toso "Responsabilidad social en la gestión de la energía: el papel del Estado y de los funcionarios públicos involucrados. A propósito del aumento de las tarifas de gas natural. Su repercusión", alude a un tema de alto impacto económico y social como es el precio del gas natural en tarifas que comenzaron a regir a partir de abril del año 2016. Finalmente, el artículo de Ariel Osatinsky: "Población ocupada, problemas de empleo, y condiciones de vida en Catamarca y Tucumán (1880-1970)", analiza los cambios demográficos y laborales en las condiciones de vida de las poblaciones de Catamarca y Tucumán en el período 1880-1970, vinculándolos con las transformaciones económicas para demostrar que la "modernización", proyectada en esa provincia desde fines del siglo XIX, no implicó un mejoramiento en las condiciones de vida, sino que más bien impactó regresivamente en las mismas.

También contamos con cuatro Reseñas. La primera de ellas realizada por Gabriel Paravano y Diego Muñoz (Universidad Nacional de San Juan), quienes reseñan el libro Avance de la Ciencia. Ciencia sin ley, Objetividad sin Ilusiones (Philip Kitcher, México D.F. , UNAM, 2001), que a pesar de no ser actual representa un interés significativo en el contexto de los debates que interesan a esta publicación. Las dos reseñas siguientes pertenecen a Facundo Di Vicenzo y refieren a las obras La Cabeza piensa y ordena y los brazos ejecutan... Representaciones sociales de la élite santafesina a comienzos del siglo XX (María Gabriela Pauli de García, Universidad Católica de Santa Fe, Santa Fe, 2017) y La Lectura y sus públicos en la edad contemporánea (Jean Yves Mollier, Buenos Aires, 
Ampersand, 2013). Por último en hemos publicado la reseña de Cecilia Pourrieux del libro Para pensar la ciencia y la técnica. Una introducción a la tecnociencia (Cristina Campagna, Mónica Giardina, Oscar Cuervo y Eduardo Lazo, Buenos Aires, Editorial FEDUN, 2017).

La tarea de responder algunas de las preguntas enunciadas al comienzo implica un esfuerzo descomunal. Las teorías no nacen en el Olimpo, al margen de la producción de los medios materiales de subsistencia y, en consecuencia, están influenciadas por el grado de desarrollo económico alcanzado en una época dada. Estas son las bases sobre las cuales han surgido las instituciones del Estado, las concepciones legales, el arte e inclusive las ideas sobre la religión de un pueblo y a cuya luz deben ser pues, explicadas, y no a la inversa como indica la tradición. Hay que desnaturalizar la idea según la cual el análisis de una teoría desde sus condicionantes históricos o materiales implicaría una suerte de relativismo o un determinismo. Es una vulgaridad cuestionar una teoría así entendida por el hecho de que resulta seguramente provisoria, que está históricamente condicionada y que, por lo tanto, en este sentido, reviste la característica de lo relativo. Sin embargo, es mediante la apelación a argumentos iguales o similares a los que se acaba de señalar, que se presenta la reacción y el oscurantismo contemporáneo. Si hay una respuesta, ésta no tendrá un carácter doctrinario en tanto esté fundada en una realidad dinámica, contradictoria y desafiante. No vamos a caer en la polémica sobre la objetividad o no de una teoría, puesto que el pensamiento no es escolástico; por el contrario, es terrenal, se asienta en la realidad y no está separado de lo práctico. Desde esta perspectiva, vamos por muchos números más.

Cristina Ambrosini, Andrés Mombrú, Pablo Martín Méndez, Cecilia Pourrieux Miembros del Comité Editor 



\section{Artículos}





\title{
La epistemología histórica en perspectiva Bachelard en la epistemología francesa
}

\author{
Naim Garnica ${ }^{1}$ \\ naim_garnica@hotmail.com \\ Rec.08/06/17, Apr.12/08/17
}

\begin{abstract}
Resumen:
El trabajo reconstruye algunas interpretaciones sobre la epistemología francesa destacando las características específicas de tal perspectiva. En ese contexto, nos enfocamos en la figura de Gastón Bachelard como un representante paradigmático de esta corriente epistemológica. Bachelard, parece ser, por un lado, un punto de inflexión entre los primeros desarrollos teóricos de la epistemología en Francia. Y, por otro lado, se constituye en una de las expresiones que mejor sintetiza el espíritu de la reflexión filosófica-histórica francesa sobre la ciencia, al influir sobre los trabajos de autores como Canguilhem o Foucault.
\end{abstract}

Palabras claves: Epistemología - Historia - Ciencia - Subjetividad

\begin{abstract}
:
The work reconstructs some interpretations on the French epistemology emphasizing the specific characteristics of such perspective. In this context, we focus on the figure of Gastón Bachelard as a paradigmatic representative of this epistemological current. Bachelard, seems to be, on the one hand, a turning point between the first theoretical developments of epistemology in France. Moreover, on the other hand, it is one of the expressions that best synthesizes the spirit of French philosophical-historical reflection on science, by influencing the works of authors like Canguilhem or Foucault.
\end{abstract}

Keywords: Epistemology - History - Science - Subjectivity

1 Licenciado en Filosofía. Docente e investigador en la Universidad Nacional de Catamarca, Facultad de Humanidades. Docente de Epistemología I en el Profesorado en Filosofía e Introducción a la Epistemología en el Profesorado en Ciencias de la Educación. 
Presentación

Intentamos reconstruir algunas interpretaciones sobre la epistemología francesa tratando de subrayar sus características específicas. En ese marco de reconstrucción interpretativa de la epistemología francesa, reconocemos en la figura de Gastón Bachelard un representante paradigmático de esta epistemología. Bachelard, parece ser, por un lado, un punto de inflexión entre los primeros desarrollos teóricos de la epistemología en Francia. Mientras que, por otro lado, se constituye en una de las expresiones que mejor sintetiza el espíritu de la reflexión filosófica-histórica francesa sobre la ciencia al influir sobre los trabajos venideros de autores como Canguilhem o Foucault.

\section{Introducción}

No hay conocimiento sin historia. En esta frase se recapitula gran parte de las reflexiones que autores franceses, como Gastón Bachelard, Michel Foucault, Jean Cavaillès, o Georges Canguilhem, han realizado sobre el conocimiento científico en el marco de la epistemología. La historia, para estos autores, constituye el espacio insuperable e inevitable para pensar la configuración del saber científico. El análisis histórico pone a la ciencia al descubierto y la enfrenta con sus fronteras, en la medida en que se conoce su constitución por diversas prácticas no-científicas. Dar cuenta de ese proceso muestra a la ciencia amarrada a relaciones que cuestionan su supuesta autonomía absoluta y objetividad libre, para dar paso a su discontinuidad y no-identidad. La epistemología en Francia, por medio de sus exponentes, parece alimentar la necesidad de aproximarse a la historia de la ciencia como una forma privilegiada de abordar los problemas epistemológicos de las ciencias, como también, de los problemas filosóficos. Así, la epistemología podría entenderse aquí como un análisis histórico en el que la crítica se centra en las condiciones históricas que hacen posible. Autores como Michel Fichant se preguntaban si, por un lado, el tránsito de la filosofía de la ciencia a la epistemología a comienzos de los años '30 constituía una verdadera ruptura teórica que abría una nueva exploración en relación a la ciencia y su estatuto. $\mathrm{O}$, por otro lado, si presentaba nada más que un neologismo, producto de una moda pasajera, que intentaba reemplazar a la filosofía de la ciencia. La respuesta a ese interrogante se desprende de tener en cuenta dos conceptos claves en el estudio de estas posiciones: el sujeto y la historia de la Ciencia. Fichant indica que estos son los:

[...] dos temas en torno a los cuales se pueden caracterizar las rupturas que introduce el nuevo concepto de epistemología que se elabora a través de las obras de Bachelard y Cavaillès, y las investigaciones de una historia de la ciencia tal como la practican Koyré y Canguilhem. (Fichant, 1982, p. 420)

Por su parte, Francisco Jarauta en su texto La filosofia y su otro explica, desde otra perspectiva, que la epistemología en Francia podría entenderse como epistemología histórica. Tales epistemologías mostrarían un proyecto de cuestionamiento frente a la idea que subyace a toda ciencia e identifica el vínculo entre la filosofía y las ciencias: la idea de sujeto. En relación a esto se podrían describirse dos posturas, escribe:

[...] dos posiciones teóricas opuestas, la que encuentra su punto de apoyo en el elemento del conocimiento (terminando necesariamente en una so- 
lución sustancialista o trascendental del problema); y la que arranca de una consideraci6n histórica del saber, que considera al sujeto histórico determinado, sin aceptar en él un nivel de autonomía o universalidad que permita considerarlo como sujeto trascendental o como conciencia empírica. (Jarauta, 1979, p. 12)

El presupuesto general de la obra de Jarauta inscribe a estas epistemologías en consonancia con los descentramientos de la razón moderna por medio de su historia. Ya no se podría, luego de la caída del mito de la razón universal que conduce el progreso de la humanidad, sostener una ciencia que se encubría en esos supuestos epistémicos. Una ciencia de esa naturaleza se engańa a sí misma y no permite una crítica de los saberes en su producción histórica. La desconfianza a una razón omnipresente, a-histórica y centrada en ella misma que explica los principios y causas por sus medios sin tener determinantes históricos, sería un rasgo común a las reflexiones epistemológicas francesas.

A ese cuestionamiento a la razón moderna, Jarauta lo aproxima a la oposición al logocentrismo. Según la postura logocéntrica que explica este autor, la ciencia se explica gracias a una razón intrínseca a sus principios, de tal modo que su conformación es trascendental, abstracta y metafísica. Pero, la comprensión de la ciencia no se puede agotar en sus propias aguas, también se halla la presencia de su relación con su historia al pasar por los ejercicios del poder, las tramas discursivas, los intereses ideológicos, los errores, su intencionalidad política, etc. Remitirse al análisis histórico no es un capricho reduccionista en la historia, sino la necesidad de deconstruir y desarmar las relaciones que elaboraron los discursos científicos en cada época.

La fractura y las grietas de la ciencia como saber absoluto y verdad infalible, desenmascara la oportunidad de pensar al sujeto del conocimiento y el saber, como también al sujeto histórico. Esto no sólo tendría validez contra el sujeto metafísico cartesiano de la filosofía moderna, sino también para el de las ciencias que se fundaron en esos sistemas filosóficos. A propósito, Jarauta indica que la tarea consistiría en: "Situarse en la mediación crítica del saber, que es tanto como decir en la crítica radical de todos los saberes, es la forma no sólo de conocer la realidad, sino de producir así las condiciones para su transformación" (1979, p. 13). La construcción del sujeto, por medio de su historia, sería el objetivo primordial de las epistemologías francesas. Esto, supone interrogarse por quién y bajo qué condiciones sociales, económicas, políticas, etc., se construyó y produjo el saber, lo cual admite realizar una reconstrucción epistemológica de las ciencias.

En otra clave de interpretación Dominique Lecourt, en Para una crítica de la Epistemología, distingue algunos rasgos comunes de los epistemólogos franceses, a pesar de sus diferencias en varios puntos. En primer lugar, el rasgo anti-positivista de estas epistemologías mantendría la presunción de que todo conocimiento se construye, ya sea por factores sociales, históricos o políticos. De ese modo, la característica central del conocimiento serían sus procesos interactivos de fuerzas y prácticas que lo organizan. Lecourt califica de positivista a todos los intentos de llevar adelante una filosofía científica como la de Reichenbach (Filosofía Científica) o una "Ciencia de la Ciencia" como expresión de una ciencia apuntada al ordenamiento lógico formal de la práctica científica. La queja fundamental sobre el positivismo recae sobre la vanidad de que la ciencia sea "[...] un conjunto de prácticas científicas como realidad homogénea, que constituye, por lo menos en principio, la unidad de una totalidad indiferenciada" (Lecourt, 1987, p. 10). Ese presupuesto encubriría la historia efectiva de las prácticas científicas, pues, cuando pien- 
sa en las ciencias lo hace de manera univoca, es decir, como "la Ciencia", para duplicarse a sí misma en una reflexión que desemboca en la "Ciencia de la Ciencia".

La idea de una "Ciencia de la Ciencia" podría encontrarse, inclusive, en la maniobra filosófica del sistema hegeliano. En la Fenomenología del Espiritu, Hegel a los efectos de la búsqueda del espíritu sobre sí mismo en el saber absoluto, termina culminando en el concepto de Ciencia, luego de atravesar las primeras oposiciones inmediatas en relación al objeto. Esto último, daría inicio a la Ciencia de la Lógica. A esta última obra, Hegel la contemplaba, en tanto categorías puras del pensamiento, las cuales, a su vez, expresaban el concepto de Ciencia en sí misma. A diferencia de una ciencia romántica que pretendía con entusiasmo, intuición y amor filial con la naturaleza localizar la verdad, Hegel proponía una ciencia que posea su propia lógica. Esto significa que la ciencia no debía buscar su fundamento o justificación fuera de ella, al igual que la filosofía, ambas deben encontrarse a sí mismas en el pensamiento que ellas representan auto-referenciándose. El argumento de Hegel era que la ciencia no se explica con elementos no-científicos, externos a ella, sino por sus propios medios, la ciencia es una tautología, una repetición circular: "Ciencia de la Ciencia".

Del mismo modo que la operación reflexiva del sistema hegeliano, el positivismo, en virtud de esa supuesta auto-reflexión de la ciencia, eleva al rango de autonomía, independencia y autosuficiencia la racionalidad científica. Lecourt sostiene que esa es una creencia ilusoria e ideológica que encubre el verdadero proceso efectivo, material e histórico del que la ciencia participa. Explica Lecourt la creencia positivista:

Una Ciencia de la Ciencia es afirmar además que la ciencia puede develar, por simple auto-reflexión, las leyes de su constitución, por ende, tanto de su funcionamiento como de su formación. Es afirmar que el "discurso científico" tiene la virtud intrínseca -y excepcional- de poder enunciar, por sí mismo, sin salir de sí, los principios de su propia teoría. Con otras palabras, el discurso científico, soberanamente autónomo, no tendría que dar cuentas a nadie y se construiría, sin choques ni obstáculos, en el espacio puro de la cientificidad instituido, instalado y delimitado por él mismo. (Lecourt, 1987, p. 11)

Esa visión sobre la ciencia conduce a entender su historia como un proceso lineal y progresivo que contiene una evolución desde los desaciertos de la ciencia hacía las verdades incuestionables. Tanto la operación hegeliana como el positivismo se fundan en una teleología que tiende a subrayar la historia de la ciencia bajo una forma evolutiva. En este punto, descansa la otra crítica común de los pensadores franceses en epistemología, esto es, su anti-evolucionismo. Aparecen, en estos autores, conceptos técnicos como: ruptura, discontinuidad, fragmentariedad, quiebres, etc., que inauguran una nueva forma de pensar el fenómeno científico y su historia. A la historia entendida como una evolución guiada por un fin, la epistemología francesa le opondría las rupturas que el pensamiento tuvo en distintas regiones del saber y cuáles fueron las condiciones históricas que permitieron su génesis. George Canguilhem, por ejemplo, se negaba a encontrar el nacimiento o los orígenes de una ciencia, no sólo por el esencialismo que eso involucra, sino también porque encubre las diversas condiciones que hicieron posible el saber. Para estos autores no existiría un descubridor, o precursor de la ciencia, o los "padres" de tal o cual ciencia ${ }^{2}$.

2 Canguilhem explica lo siguiente: “¿Cuál es, entonces, para el historiador de las ciencias el efecto 
Naim Garnica/ La epistemología histórica en perspectiva[...]/17

Aparentemente, de lo que se trataría es de realizar una historia de los conceptos y problemas de la ciencia. En resumen, si adoptamos la lectura de Lecourt podemos afirmar que:

El contenido positivo de la diferencia especifica de esta tradición epistemológica, hasta aquí enunciado en forma negativa y polémica. Su no-positivismo y anti-evolucionismo provienen de la unión que reconocen entre la Epistemología y la práctica efectiva de la historia de las ciencias. (Lecourt, 1989, p.15)

Cabe aclarar que la interpretación de este autor no es demasiado optimista frente a los proyecto de Bachelard o Foucault. Lecourt es muy duro en sus comentarios, calificando a estas propuestas epistemológicas de "fracasos". A juicio de Lecourt, estos proyectos no consiguen ser lo suficientemente revolucionarios si los comparamos con el marxismo, de quien el autor sería partidario. Incluso, en varios de los artículos compilados del libro que tomamos prestadas las anteriores ideas, Lecourt no puede sino leer a estos pensadores desde el marxismo y destacar aquellas categorías que entiende como compañeras y aliadas de dicha corriente.

Otra perspectiva interesante de tener en cuenta sobre la epistemología francesa podría ser la que ofrecen los estudios de comentaristas como Gary Gutting. En su texto denominado French Philosophy in The Twentieth Century este autor le dedica a la emergencia de la preocupación por la ciencia un apartado. Su reconstrucción histórica del pensamiento francés en torno a la ciencia se detiene en los pensadores de los primeros años del siglo XX. A su juicio, lo importante de estas décadas radicaría en la creciente autonomización de la reflexión filosófica en torno a la ciencia. Dicha tarea estaría representada en las obras de Henri Poincaré, Duhem y Emile Meyerson. En estos autores se comenzaría a consolidar la epistemología francesa o, por lo menos, sus tempranas reflexiones en torno al fenómeno científico. Gutting sostiene que, a partir del kantismo y a pesar de sus cercanías al positivismo o empirismo, estos autores lograron advertir la importancia de la participación reflexiva en la construcción del objeto de conocimiento. Junto a León Brunschvicg, estos autores constituyen uno de los intentos más serios de enfrentarse al fenómeno de las ciencias y su historia. A juicio de Gutting, estos autores podrían ser clasificados dentro de la filosofía francesa de la tercera República que llegaría hasta la década del ’40. El autor caracteriza este período de la epistemología francesa en el siguiente marco:

In principle, the new epistemology of science could have remained entirely subordinated to the goals of the metaphysics of nature. In practice, it emerged as more and more an autonomous study of science in its own terms, with decreasing concern for including scientihc results in a synthetic metaphysical view of nature as a concrete whole. (Gutting, 2001, p.27) ${ }^{3}$

práctico de una teoría que tiende a reconocerle la autonomía de una disciplina que se constituye en el lugar donde son estudiadas las cuestiones teóricas planteadas por la practica científica? Uno de los efectos prácticos más importantes es la eliminación de lo que J. T. Clarck ha llamado "el virus del precursor" (18). En rigor, si existieran precursores, la historia de las ciencias perdería todo sentido, ya que la ciencia misma no tendría una dimensión histórica sino en apariencia. Si en la Antigüedad, en la época del mundo cerrado, alguno hubiera podido ser, en cosmología, el precursor de un pensador de la época del universo infinito, un estudio de historia de las ciencias y de las ideas como el de Alexandre Koyré (19) sería imposible. Un precursor sería un pensador, un investigador, que habría hecho ya entonces un extremo del camino acabado más recientemente por otro. La complacencia en investigar, en encontrar y en celebrar a los precursores es el síntoma más neto de ineptitud en la crítica epistemológica" (1968, pp. 9-10).

3 En principio, la nueva epistemología de la ciencia podría haber permanecido completamente subor- 
Los desarrollos de estos pensadores habrían permitido la consolidación de cierto tipo de idealismo que colaboraba con una crítica al dogmatismo científico. En esa dirección, nos parece que situar la atención sobre la obra de Gastón Bachelard puede ser una clave para entender estas perspectivas sobre la epistemología francesa.

Los análisis de Bachelard, mediante su profundo conocimiento de la historia y la práctica actual de la ciencia, lo relacionan inmediatamente con la tradición de Poincaré, Meyerson y Boutroux. Sin embargo, la relación de la ciencia y la filosofía que se puede notar en su obra, parece derivar directamente de León Brunschvicg y Abel Rey (quienes orientaron su trabajo doctoral). Al igual que Brunschvicg, Bachelard sostiene que la filosofía debería elaborar una comprensión de la razón y sus procesos a través de la reflexión sobre el desarrollo histórico de la ciencia. En particular, los estudios de caso en la historia de las matemáticas y las ciencias físicas. Pese a ello, Bachelard enfatiza mucho más que Brunschvicg el papel de la discontinuidad en el desarrollo de la ciencia $y$, al menos, intenta evitar la prioridad, tal vez excesiva, del idealismo sobre el realismo. En ese contexto, la virtud de Bachelard dentro de la epistemología francesa radicaría en dialectizar al conocimiento científico a los efectos de pensarlo en continuo movimiento, en su dinamismo y permanente cambio en función de su historia. Bachelard, creemos, expone un gran testimonio de ese sacudón a la razón científica que la epistemología francesa muestra independientemente de qué perspectiva intente explicarla.

\section{Bachelard y la Historia de la Ciencia}

Gastón Bachelard (1884-1962) acude, en el ámbito de la problemática epistemológica, a los acontecimientos que atañen a la relación filosofía-ciencia, y afirma desde su análisis, un trabajo histórico sobre las ciencias, una construcción de un racionalismo aplicado que permite pensar los nuevos sucesos científicos del siglo XX. Su presupuesto fundamental radica en la observación de la inadecuación de las filosofías espiritualistas y positivistas para lo que él denomina "el nuevo espíritu científico". Precisamente, en su obra La formación del espiritu científico Bachelard presenta su consideración de la historia de ese espíritu y cuál sería la novedad que inaugura el nuevo período:

[...] si por razones de claridad, se nos obligara a poner groseras etiquetas históricas en las diferentes etapas del pensamiento científico, distinguiríamos bastante bien tres grandes períodos. [1] El primer período, que representa $e l$ estado precientífico, comprendería a la vez la antigüedad clásica y los tiempos de renacimiento y de nuevos esfuerzos, con los siglos XVI, XVII y aún el XVIII. [2] El segundo período, que representa el estado cientifico, en preparación a fines del siglo XVIII, se extendería hasta todo el siglo XIX y comienzos del XX. [3] En tercer lugar, fijaríamos exactamente la era del nuevo espiritu cientifico en 1905, en el momento en que la Relatividad einsteiniana deforma conceptos primordiales que se creían fijados para siempre. A partir de esta fecha, la razón multiplica sus objeciones, disocia y reconfigura las nociones fundamentales y ensaya las abstracciones más audaces. En veinticinco años, como signos de una asombrosa madurez espiritual, aparecen

dinada a los objetivos de la metafísica de la naturaleza. En la práctica, surgió cada vez más como un estudio autónomo de la ciencia en sus propios términos, con una preocupación decreciente por incluir los resultados científicos en una visión metafísica sintética de la naturaleza como un todo concreto. 
tales pensamientos, que uno sólo de ellos bastaría para dar lustre a un siglo. Son la mecánica cuántica, la mecánica ondulatoria de Louis de Broglie, la física de las matrices de Heisenberg, la mecánica de Dirac, las mecánicas abstractas y, sin duda, muy pronto las físicas abstractas que ordenarán todas las posibilidades de la experiencia. (Bachelard, 2000, p. 9)

Motivado por el desarrollo científico a inicios del siglo XX de la geometría no-euclidiana, la mecánica no-newtoniana, la física no-maxwelliana, la Aritmética, las cuales comienzan a producir rupturas y contra-discursos que no eran habituales en la tradición científica, Bachelard emprende la tarea de construir una nueva filosofía para las categorías emergentes y contemporáneas. Jarauta señala que la intención de esta obra es “[...] pasar de una verificación de la inadecuación a la definición de los caracteres de una epistemología no-cartesiana, que corresponda a la novedad del espíritu científico contemporáneo" (1979, p. 35). La novedad introducida por el autor francés en el análisis epistemológico radicaría en la forma histórica de abordar los procesos de las ciencias como los de la filosofía, además de la relación entre ambas. Ello pone en crisis la comprensión mecanicista y esencialista de las filosofías que tienen a la ciencia como su objeto ideal, sin ver efectivamente su práctica concreta. Se exige por tanto que la filosofía se comporte en la mediación histórica entre las ciencias y sus procesos históricos orientándose por aquellos procesos de la realidad que se manifiestan en la historia de sus conceptos. Eso implica detenerse en las rupturas, variaciones y desplazamientos históricos que el espíritu de las ciencias realiza, lo cual lleva a cambiar el eje de consideración sobre el modo de desenvolvimiento histórico de las mismas. No se puede pensar, a partir de esta epistemología, una historia de la ciencia como hechos concatenados, a modo de un domino en el que una pieza anterior permite el movimiento de la siguiente, sino de un proceso de renovación por medio de rupturas y discontinuidades ${ }^{4}$. De hecho, Bachelard sostiene que "[...] el espíritu tiene una estructura variable a partir del momento en que el conocimiento tiene una historia" (1974, p. 141).

Siguiendo a Bachelard, podemos ilustrar lo siguiente. Por ejemplo, Descartes pertenece a una coyuntura científica particular y, es en función de la particularidad, que desarrolla su discurso filosófico. En coherencia con ese momento se adecua a los problemas epistemológicos de la ciencia de su tiempo: la geometría, la física, la matemática, etc., en el desarrollo que habían alcanzado en aquel momento. Pero, ante las modificaciones en el discurso científico, ¿qué validez posee el cartesianismo? Bachelard piensa el proceso de las ciencias a partir de aquel otro proceso de complejidad progresiva de la experiencia que, a su vez, se reflejaría en el orden del saber y en el de sus construcciones: los discursos históricos ${ }^{5}$. De esa manera, el cartesianismo no posee problemas en sí mismo, sino bajo las dificultades históricas que presenta al no abrirse a las nuevas experiencias. Por ello, afirma:

4 Pueden ampliarse estas consideraciones en La filosofía del no (1984) de Bachelard.

5 Seguimos aquí las indicaciones de Tiles, Mary (2005) en "Technology, Science, and Inexact Knowledge: Bachelard's Non-Cartesian Epistemology". Su análisis se centra en el temprano texto bachelardiano La Essai sur la connaissance approche'e de 1928 a los efectos de mostrar la impugnación al modelo cartesiano del dualismo como del fundacionalismo de la verdad. Tiles sostiene que la epistemología de Bachelard se perfila en este texto ya como una confrontación con el cartesianismo a partir de advertir la multiplicidad de posibilidad de enfrentarse con la realidad a partir de la historia. En última instancia, Bachelard asumiría un postulado radical de la epistemología francesa que rechazaría el intelectualismo y reduccionismo heredado de la tradición cartesiana. 
[...] deberemos llegar a esta conclusión si queremos definir la filosofía del conocimiento científico como una filosofía abierta, como la conciencia de un espíritu que se fundamenta trabajando en lo desconocido, buscando en lo real aquello que contradice conocimientos anteriores. Ante todo, hay que tomar conciencia del hecho que la experiencia nueva dice no a la experiencia nueva. (Bachelard, 1974, p. 145)

Ni la filosofía, ni las ciencias se construyen per se, en realidad, la filosofía necesariamente se encuentra involucrada en la intervención de los discursos que construyen el saber científico. Por eso, para Bachelard, el espíritu científico es una rectificación permanente del saber ${ }^{6}$, procura ampliar sus formas de construcción. El saber, entonces, no es la acumulación de datos e informaciones que a lo largo de la historia se han desarrollado, sino la conciencia de sus errores rectificados en términos históricos. El pensamiento producido por la actividad científica debe desarrollarse para Bachelard si captamos los obstáculos que se presentan. La categoría de obstáculo epistemológico ${ }^{7}$ el autor la entiende como un rasgo propio del conocimiento, que no es ni externo, ni interno. Sin excepción, los conocimientos, poseen confusiones, desvíos, deformaciones, etc. que pueden poner un impedimento al espíritu. Sin embargo, el autor indica que el mayor peligro de los obstáculos es la experiencia, por eso "[...] es necesario que el pensamiento abandone al empirismo inmediato" (Bachelard 2000, p.23).

A través de los obstáculos Bachelard señala la clave de los problemas del conocimiento, ya que permiten observar: contradicciones, confusiones, entorpecimientos, retrocesos, dogmatismo, y estancamientos. Lo que se debe comprender aquí es el rasgo constitutivo del obstáculo epistemológico al conocimiento, esa traba al espíritu de la ciencia no es responsabilidad ni de los sentidos, ni del pensamiento:

[...] es en el acto mismo de conocer, íntimamente, donde aparecen, por una especie de necesidad funcional, los entorpecimientos y las confusiones. Es ahí donde mostraremos causas de estancamiento y hasta de retroceso, es ahí donde discerniremos causas de inercia que llamaremos obstáculos epistemológicos. El conocimiento de lo real es una luz que siempre proyecta alguna sombra. (Bachelard, 2000, p. 15)

Frente a este problema Bachelard propone la abstracción, pero no entendida como opuesta a lo concreto, como pensaría el positivismo, sino como una forma de no caer en la inmediatez de la experiencia que tiende a formular la opinión. Tanto la opinión, como el conocimiento de experiencia serían el enemigo al que se enfrenta la abstracción del espíritu científico.

6 Jean Gayon en "Bachelard y la historia de las ciencias" afirma que la idea de una rectificación permanente como la de la imposibilidad de clausurar el proceso crítico de la razón "se encuentra en todas las obras epistemológicas, desde la primera tesis de 1927 hasta Le matérialisme rationnel" (2006, p.63).

7 Gary Gutting (1987) en "Gaston Bachelard's philosophy of science", sostiene que la noción de obstáculo epistemológico podría ponerse en relación a la tradición angloparlante o filosofía analítica de la epistemología. Según su consideración, esta noción permitiría identificar las dificultades metafísicas o dogmáticas del conocimiento que la tradición anlgo-americana también se ha esforzado en impugnar. También, Christopher Norris sugiere esta comparación en "Deconstruction and Epistemology" (2001, pp. 69-100). 
La abstracción nos permite formular los verdaderos problemas de la ciencia. Esto supone pensar que en:

[...] la vida científica los problemas no se plantean por sí mismos. Es precisamente este sentido del problema el que sindica el verdadero espíritu científico. [...] Si no hubo pregunta, no puede haber conocimiento científico. Nada es espontáneo. Nada está dado. Todo se construye. (Bachelard 2000, p. 16)

Esta declaración antipositivista, en tanto nada está dado, y todo se construye, permite identificar el gran esfuerzo de la obra bachelardiana por combatir el obstáculo de la experiencia inmediata, o conocimiento empírico, como forma de dogmatismo y entorpecimiento de las ciencias. El obstáculo epistemológico también puede surgir como una forma de ilusión ante la ruptura del pensamiento, intentando suturar las grietas. Cuando una estructura histórica científica ha sido negada, o la novedad aparece para dar cuenta de una ruptura, el obstáculo puede presentarse para rellenar esa ruptura y volver todo a la calma. Ante esto, debemos desconfiar de la identidad y la continuidad, un verdadero espíritu científico confía en el movimiento y la dialéctica del espíritu. No es casual que Bachelard al final de La formación del espiritu científico sostenga que: "[...]al lado de la historia de lo que fue, lento y hesitante, debe escribirse una historia de lo que ha debido ser, rápido y perentorio" (2000, p. 295).

De ese modo, la evidencia histórica del "[...] progreso científico marca sus más puras etapas abandonando los factores filosóficos de unificación fácil, tales como la unidad de acción del Creador, la unidad de plan de la Naturaleza, la unidad lógica" (Bachelard 2000, p. 18). De hecho, la variación y el cambio en la epistemología de Bachelard son capitales para entender el proceso histórico del espíritu científico. Veamos un pasaje que reúne lo expuesto:

El espíritu científico jamás se siente impedido de variar las condiciones, en una palabra, de salir de la contemplación de lo mismo y buscar lo otro, de dialectizar la experiencia. Así es como la Química multiplica y completa sus series homologas, hasta salir de la Naturaleza materializando cuerpos más o menos hipotéticos sugeridos por el pensamiento inventivo. Es así como en todas las Ciencias rigurosas, un pensamiento ansioso desconfía de las identidades. [...] Precisar, rectificar, diversificar, he ahí los tipos del pensamiento dinámico que se alejan de la certidumbre y de la unidad, y que en los sistemas homogéneos encuentran más obstáculos que impulsos. (Bachelard, 2000, p. 19)

Esa rectificación del error es una extensión del complemento del pensamiento o lo que se denomina racionalismo aplicado. El racionalismo en la epistemología bachelardiana no debe entenderse como una corriente clásica de la Teoría del Conocimiento. $\mathrm{Su}$ racionalismo es entendido en relación a los cambios que produce una conciencia o espíritu que busca las contradicciones de los conocimientos anteriores a partir de la novedad. "El racionalismo aplicado a diferencia del racionalismo clásico es más revolucionario, es una razón turbulenta, audaz, agresiva, e intenta multiplicar las posibilidades del pensamiento" (Gracia, 2000, p. 269). El espíritu para Bachelard es siempre incompleto, por lo que se encuentra en lucha con él mismo siendo polémico y revolucionario ya que 
el espíritu no pretende adecuarse, sino adaptarse en el proceso histórico a las rupturas y novedades. Por eso indica:

Sólo la razón dinamiza a la investigación, pues sólo ella sugiere, más allá de la experiencia común (inmediata y especiosa), la experiencia científica (indirecta y fecunda). Es, pues, el esfuerzo de racionalidad y de construcción el que debe atraer la atención del epistemólogo. El historiador de la Ciencia debe tomar las ideas como hechos. El epistemólogo debe tomar los hechos como ideas, insertándolas en un sistema de pensamientos. Un hecho mal interpretado por una época, sigue siendo un hecho para el historiador. Según el epistemólogo es un obstáculo, un contrapensamiento. Será, sobre todo, profundizando la noción de obstáculo epistemológico cómo se otorgará su pleno valor espiritual a la historia del pensamiento científico. (Bachelard, 2000, p. 20)

El espíritu del racionalismo aplicado parece explicarse como una dialéctica histórica que nunca se cierra en sí misma. Para Bachelard no hay continuidad entre pensamiento y realidad, sino una razón histórica que construye el conocimiento en negación tras negación. Esa dialéctica debe entenderse en un sistema de complementos o complementariedad donde lo anterior aparece en lo nuevo, pero renovado críticamente y superado, pues "[...] hasta en un espíritu claro, hay zonas oscuras, cavernas en las que aún residen las sombras. Hasta en el hombre nuevo, quedan vestigios del hombre viejo" (Bachelard 2000:10). A contramano de la absolutización de la razón, el racionalismo aplicado no se detiene y permite pensar las rupturas, lo desconcertante, las negaciones y las discontinuidades del pensamiento en la historia. El saber científico exige su incansable renovación en la historia, de allí que Bachelard insiste en "[...] el hecho de que no puede prevalerse de un espíritu científico, mientras no se esté seguro, en cada momento de la vida mental, de reconstruir todo su saber. Sólo los ejes racionales permiten tal reconstrucción. El resto es baja mnemotécnica” (Bachelard, 2000, p. 10).

Este pensador francés al inicio de su texto en oposición a la epistemología positivista que encuentra el testimonio de la ciencia en la experiencia y en contra del continuismo histórico de Meyerson señala:

Una experiencia científica es, pues, una experiencia que contradice a la experiencia común. Por otra parte, la experiencia inmediata y usual mantiene siempre una especie de carácter tautológico, ella se desarrolla en el mundo de las palabras y de las definiciones, y carece precisamente de aquella perspectiva de errores rectificados que caracteriza, según nuestro modo de ver, al pensamiento científico. Llamativo que la antigua Epistemología haya establecido una vinculación continúa entre la observación y la experimentación, cuando la experimentación debe apartarse de las condiciones ordinarias de la observación. Como la experiencia común no está compues$t a$, ella no podría ser, creemos nosotros, efectivamente verificada. Pensar una experiencia es entonces mostrar la coherencia de un pluralismo inicial. Mas por hostiles que seamos a las pretensiones de los espíritus "concretos", que creen captar inmediatamente lo dado, no trataremos de incriminar sistemáticamente toda intuición aislada. (Bachelard, 2000, pp. 13-14) 
Naim Garnica/ La epistemología histórica en perspectiva[...]/23

Bachelard reconoce que la historicidad podría ser esencial al objeto de la filosofía de la ciencia. Así, las ciencias como un sistema de prácticas articuladas, sería, en el sentido histórico, relaciones determinadas históricamente de producción de conceptos.

\section{Consideraciones finales}

Finalmente, Bachelard parece emplear como regla epistemológica la atención al trabajo científico efectivo, entendiéndolo como una práctica concreta. Su revolución filosófica radica en tener en cuenta que las esferas del saber en cada momento histórico producen sus normas de verdad, algo que compartirá con Canguilhem y Foucault ${ }^{8}$. Este planteo subraya la dimensión artificial de las ciencias, en tanto, constituyen una forma de producción, además de dar cuenta de su carácter social. La artificialidad de la ciencia muestra su capacidad creativa por cuanto recurre a construcciones metafóricas que configuran espacios y definen formas de intervención en la práctica. Cabe aclarar que la capacidad creativa de la ciencia no puede pensarse desprendida de su historia, el sujeto de la ciencia se ve limitado por su historia y su espacio social. Esto expresa: la historicidad de los esquemas científicos, la socialización de la ciencia contemporánea y el límite de la imaginación en el colectivo social (Lecourt 1987, pp. 43-44).

De ese modo, la maniobra que realiza Bachelard aparentemente revocaría la categoría absoluta de verdad en nombre de la práctica efectiva de las ciencias. Así, le impugna a la filosofía el derecho de decir la verdad de las ciencias, pues para el francés los filósofos mantienen frente a las ciencias una relación de distancia con el trabajo efectivo de los científicos. El objetivo general que Bachelard persigue es próximo a una "[...] cultura científica en estado de movilización permanente, reemplazar el saber cerrado y estático por un conocimiento abierto y dinámico" (2000, p. 21). Los filósofos no tienen objeto, viven en lo imaginario, viven de lo imaginario, lo cual no les permite remitirse a una práctica científica con lo pleno de un objeto que tuviera toda consistencia de lo "real".

Por lo tanto, Bachelard entiende haber construido el psicoanálisis del conocimiento objetivo para poder franquear al conocimiento de los valores empiristas conservadores. Ello consiste en una catarsis para el uso de los científicos. Su función es protegerse de los espejismos filosóficos y no caer en detenciones del espíritu, a los fines de dinamizar al conocimiento y ayudar a decir cuál es la filosofía de la práctica real, esto es: proyectar la oscuridad que la luz del conocimiento encubre. Por eso, el autor otorga un lugar a la filosofía entre la práctica científica y las ideologías que intervienen. Si los científicos no saben cuál es la filosofía que está detrás de sus prácticas, la epistemología histórica puede reconstruirla, de ahí su doble tarea: polemizar, con los filósofos y científicos, e historizar.

\section{Bibliografía}

—Bachelard, G. (1976). El materialismo racional. Bs. As.: Paidós.

—Bachelard, G. (1974). Epistemología. Barcelona: Anagrama.

—Bachelard, G. (1978). El racionalismo aplicado. Buenos Aires: Paidós.

—Bachelard, G. (1984). La filosofía del no. Buenos Aires: Anagrama.

8 Véase el estudio de Macherey, P. (2011). De Canguilhem a Foucault: La fuerza de las normas. Bs.As.: Amorrortu. 
—Bachelard, G. (2000). La formación del espiritu científico. Buenos Aires. Siglo XXI.

—Canguilhem, G. (1968). "L' object de l'histoire des Sciences". En Canguilhem, G., Études d'Histoire et de philosophie des Sciences, (pp. 9-23), Paris: J. Vrin.

—Díaz, E. (2012). El poder y la vida. Modulaciones epistemológicas. Buenos Aires: Biblos.

—Fichant, M. (1982). "La Epistemología en Francia”. En Chatelet, F. La historia de la filosofía. Madrid: Espalsa-Calpe.

—Gayon, J. (2006). "Bachelard y la historia de las ciencias". En Wunenburger, J-J. (coord.) Bachelard y la epistemología francesa (pp. 39-86.) Buenos Aires: Nueva Visión.

—Gracia, M. C. (2000). "Una perspectiva sobre la epistemología francesa”. En Díaz, E. La Posciencia: el conocimiento cientifico en las postrimerías de la modernidad (pp.265-277), Buenos Aires: Biblos.

-Gutting, G. (2001). French Philosophy in The Twentieth Century. UK: Cambridge Press.

—Gutting, G. (1987). "Gaston Bachelard's philosophy of science". International Studies in the Philosophy of Science, 2 (1), pp. 55-71.

- Jarauta, F. (1979). La filosofia y su otro. Cavailles, Bachelard, Canguilhem, Foucault. Madrid: Editorial Pre-textos.

-Lecourt, D. (1987). Para una critica de la epistemología. Madrid: Siglo XXI.

-Macherey, P. (2011) De Canguilhem a Foucault: La fuerza de las normas. Buenos Aires: Amorrortu.

—Norris, C. (2001). "Deconstruction and Epistemology". Paragraph, pp. 69-100.

-Tiles, M. (2005). “Technology, Science, and Inexact Knowledge: Bachelard's Non-Cartesian Epistemology”. En Gutting, G. (Ed.) Continental Philosophy of Science (pp.157-175). UK: Blackwell Publishing, Ltd. 


\title{
Las políticas educativas en la Historia de la Educación Un aporte para el estudio de las políticas educativas, en el Centenario de la Revolución Argentina
}

\author{
Laura S. Guic ${ }^{1}$ \\ magisterunla@gmail.com \\ Rec.18/04/17, Apr.22/05/17
}

\begin{abstract}
Resumen
El presente trabajo presenta avances en la investigación de la política educativa de principios de siglo XX. El punto de partida son las acciones del Consejo Nacional de Educación en Argentina en torno a los festejos del Centenario hacia 1910, empleando categorías de análisis que se construyen para analizar las políticas educativas en la actualidad. Estudiar los antecedentes de las políticas educativas de los albores del siglo XX propicia la detección de variables que produjeran transformaciones visibles en las prácticas de las escuelas hasta el presente; de allí el éxito de su implementación. La cuestión de la crisis educativa actual es abordada por múltiples investigaciones que intentan elucidar, de las políticas públicas, tanto las causas de sus fracasos como los desafíos para el cambio requerido.
\end{abstract}

Palabras clave: Estado - políticas educativas - gobierno - educación sistema educativo.

\begin{abstract}
The question of the current educational crisis is addressed by multiple investigations that try to elucidate, from public policies, both the causes of their failures and the challenges for the required change. The present work presents, advances in the investigation of the education policy of the Centenary, in relation to the government of education, around the management of the presidency of the National Council of Education in Argentina, towards 1910; Through a novel approach, using categories of analysis that are constructed to analyze the education policies of the last decades. Studying the origins of these educational policies at the dawn of Siglo XX, favors the detection of variables that produce visible transformations in the practices of schools to the present; Hence the success of its implementation.
\end{abstract}

1 Licenciada en Gestión Educativa (UNLA). Especialista en Investigación Educativa (UNLA). Doctoranda del Programa Interuniversitario de Educación. Investigadora del Instituto de Cultura de la Universidad Nacional de Lanús. 
Key words: State - educational policies - government - education educational system.

\section{Los aportes del estudio de las políticas educativas}

El presente artículo expone los avances de un trabajo de indagación que emplea herramientas metodológicas, devenidas de la investigación de las políticas educativas, para el estudio de las transformaciones educacionales de los orígenes de la instrucción pública, con el objetivo de contribuir a la comprensión de los procesos efectivos de cambio que se sostienen a través del tiempo.

Tanto el planeamiento como la gestión de las políticas educativas han sido indagadas con el propósito de afrontar las crisis educacionales de los últimos años en América Latina y en particular en Argentina. Los incipientes estudios surgen como una periodización del Estado planificador que se afianza hacia la segunda mitad de la década 1940 y los primeros años de la década siguiente. Así, los esquemas interpretativos han ido superando la delimitación de dimensiones estáticas en la comprensión del planeamiento, yendo desde una interrelación de tres componentes de gobierno: político, administrativo y planificador (Aguerrondo y Lamarra, 1978, p. 391) hacia una ampliación y profundización del sistema referencial, tanto en su marco conceptual como relacional.

[...] a pesar de todas las decisiones, acciones y esfuerzos nacionales, la educación en América Latina muestra fuertes desigualdades en cuanto a la atención de los diversos grupos de población, en la calidad de la educación que se ofrece, en los niveles de formación de sus docentes, en la incorporación de los contenidos provenientes de la Sociedad del Conocimiento, en la utilización de las nuevas tecnologías de la información y de la comunicación, etc. (Lamarra, 2007, p. 17)

Otros investigadores, remarcan la "[...] necesidad de una perspectiva histórica que permitiera reconstruir los procesos de surgimiento, desarrollo y resolución de cuestiones sociales, dentro de los cuales las políticas públicas cobran sentido" (Ozlack,1990, p. 1).

Para poder desentrañar del contexto de la crisis actual los obstáculos que ponen en el centro del debate la imposibilidad de transformar una educación para el futuro, es entonces preciso revisar, en el origen, aquellas políticas educativas que superaron los embates del tiempo, entre lo instituido y lo instituyente.

\section{Marco teórico metodológico para el estudio de las políticas educativas}

Lo propio de la investigación histórica es la exploración de fuentes documentales para el análisis de los discursos que los entraman. Esto también vale para la Historia de la Educación, donde se emplean las herramientas de la disciplina, aunque sin reparar en las complejidades y particularidades propias del campo. Por ello, el estudio de las últimas décadas de las políticas educativas crea condiciones de posibilidad para examinar los sistemas educativos en el origen, desde una perspectiva superadora que favorezca la comprensión del pasado en relación con las necesidades del presente y futuro educativo en crisis. 
Laura Guic/ Las políticas educativas en la Historia de la educación [...]/27

Por otra parte, surge el problema de consolidar un enfoque desde la perspectiva del gobierno de la educación, poniendo el foco en los debates que se instalan en los espacios de toma de decisión y ejecución de las políticas. Lamarra (2012) propone para el análisis del planeamiento un marco teórico-conceptual, que lo ubica como una dimensión más en el proceso estratégico de gobierno, y ello permite identificar, en el origen del sistema educativo argentino, la perspectiva del gobierno a la luz de categorías que operen, en principio, evitando el estudio fragmentado por etapas; estableciendo la interrelación entre el planeamiento, la política, la evaluación, el seguimiento y evaluación como dimensiones del proceso estratégico de gobierno, sin perder de vista los aspectos distintivos de cada una (Lamarra, 2006). Para el autor, la planificación es un componente del proceso complejo del gobierno educativo, de allí la matriz que enmarca las dimensiones para su abordaje. Esta forma de mirar las políticas, retroalimentando unas dimensiones con las otras interrelacionadas, evita las situaciones de aislamientos de cada variable, teniendo en cuenta que cada una de ellas tiene lógicas diferentes. Se propone aquí tomar este esquema para leer -en el origen de la instrucción pública- las políticas del Centenario como antecedentes de las políticas educativas vigentes, teniendo presentes los riesgos de construir modelos categoriales del presente para introducirlos en contextos diferentes.

Asimismo, la descripción del contexto político, económico, social, cultural y educativo (Lamarra, 2002) favorecen, en la exploración de la instrucción pública, la posibilidad de establecer dos etapas de conformación al interior de su periodización, que para este estudio serán: el de las Presidencias Nacionales (1862-1880) y el Orden Conservador (1880-1916). La replicabilidad de los marcos teóricos conceptuales configuran una matriz categorial propicia para estudiar una política educativa de principios del siglo XX: "La escuela del Centenario".

\section{Una aproximación a las políticas educativas del Centenario}

La relevancia de estudiar las políticas educativas en la primera década del siglo XX se explica a través de las tesis planteadas por muy diversos estudiosos, que las caracterizan como un proyecto consolidado, a través del cual se llevó a cabo una transformación que satisfacía en principio los objetivos de alfabetización y construcción de la identidad nacional de sus promotores. Queda claro que poner una política en agenda supone, entre otras cuestiones, contar con el poder para instalar el debate y con un lugar en el Estado para su implementación, además de los recursos para fundarlas y sostenerlas en el tiempo.

En en la década del ' $70^{2}$, al fomular su tesis sobre el origen del sistema educativo y las políticas implementadas entre fines del siglo XIX y principios del XX, Juan Carlos Tedesco sostenía que:

[...] la sanción de las leyes educacionales que organizaron respectivamente los ciclos primarios y superior de la enseñanza, y la práctica de una determinada política educacional coherente en todos sus ámbitos, resultaron los hechos más notables del período, y, por encima de cualquier otra consideración valorativa, la vigencia de esas leyes y de esa política durante casi todo un siglo, demuestra que estamos frente a un hecho de verdadera relevancia. (Tedesco, 2002, p. 19)

2 La primera formulación de su hipótesis se encuentra en la primera edición de "Estado y educación en la Argentina (1880-1990)" Buenos Aires, Ediciones Pannedille,1970. 
Por su parte, Escudé sostiene que el éxito del proyecto extremista de Educación Patriótica, diseñado e implementado hacia 1908 por Ramos Mejía, "garantizó el fracaso nacional", responsabilizando, en parte, al fracaso del proyecto liberal argentino, determinándola como variable cultural endógena (Escudé, 1990, pp. XXX).

Desde otros enfoques que indagan por un lado la educación comparada (Ruiz, 2016) y, por el otro, la educación como derecho (Scioscioli, 2015), se afirma que la única transformación efectiva, en términos educacionales, es la que se efectúa hacia fines del siglo XIX y principios del siglo XX. Por ello es oportuno investigar en las fuentes las construcciones discursivas desde y para el Estado. Llevando la matriz categorial al origen y abriendo juego a este trabajo, se recupera un documento publicado en 1909 por el Consejo Nacional de Educación (en adelante CNE): "La Escuela Argentina en el Centenario", que reúne los proyectos de su presidente, el Dr. José María Ramos Mejía.

Hacia 1899, Ramos Mejía publica Las multitudes argentinas, donde pone en claro el diagnóstico del problema del inmigrante, y el temor de la élite dirigente a la pérdida del gobierno propio. Es importante señalar que, en los primeros años del siglo XX, este médico argentino, como exponente del espacio de salud ${ }^{3}$, diseña los contenidos del Programa de Educación Patriótica (1908 y 1913) (Guic, 2016).

La aplicación de las dimensiones contextuales muestra progresos parciales de la investigación en torno a las inscripciones del proyecto del Centenario:

El diseño e implementación del programa del Centenario se desarrolla en un momento particular de principios del XX, marcado por los resultados "no deseados" de las políticas inmigratorias. Fruto del problema del desierto argentino, resuelto a través de las exitosas políticas de inmigración, se crea un nuevo problema: la cuestión del inmigrante, que viene a poner en riesgo al gobierno propio de la élite dirigente. (Herrero, 2010). Los hijos de inmigrantes, que a pesar de ser argentinos seguían la cultura de sus padres, podían, por derecho constitucional, ocupar cargos en el Estado.

La propuesta educativa de gobierno se deliberó en el marco de un profundo debate sobre la función de la educación. El roquismo propone en sus mandatos, y a través de los proyectos de Magnasco y Saavedra Lamas, vincular la educación con el mundo del trabajo (Muzzopappa: 2015). Es en ese orden conservador de los últimos años del roquismo, conicidente con el Centenario de la Revolución en Argentina, donde se diseñan, debaten, y ejecutan planes de transformación en la educación. Cabe recordar también que, hacia el Centenario, Argentina desarrolla su economía en el marco de la distribución internacional del trabajo, a través del modelo agroexportador. Aquí entran dos perspectivas totalmente diferentes para comprender la transformación en las funciones de la educación. Tedesco sostiene que la expansión del sistema educativo no se realizó en función de exigencias económicas, sino en virtud de formar ciudadanos y funcionarios para la burocracia del Estado (Tedesco, 2003, p. 83). Por su parte, Cirigliano afirma que existe una correspondencia activa y que la educación cumple una función económica según los requerimientos del modelo agroexportador ${ }^{4}$.

Respecto del contexto cultural, puede señalarse brevemente que la constitución de la nación Argentina se identifica con Europa; lo cual se evidenciaba con la participación de las monarquías en los festejos del Centenario.

3 J. M. Ramos Mejía formó parte del Círculo inteligente de la Argentina de los años del Centenario de la Revolución de Mayo.

4 "todo estaba determinado para un previo mercado de puestos. La clase baja cosecha y faena; la clase media embala; la clase alta dirige la operación". Cirigliano G. F. J. (citado por Tedesco, 2003, p. 83). 
Laura Guic/ Las políticas educativas en la Historia de la educación [...]/29

Por último, en cuanto al contexto educativo y su marco jurídico, la Ley 1420 (1884), con sus resoluciones complementarias, y la Ley Lainez (1905) privilegian un formato piramidal, cuya base es la escuela primaria.

La publicación comprende doce proyectos que se diseñan desde la presidencia del Consejo. El objetivo manifiesto es la participación activa de la escuela en los festejos del Centenario de la Revolución de Mayo, introducidos con una carta de Ramos Mejía que dice:

Esta presidencia piensa que el Consejo Nacional de Educación debe tomar una participación principal en la celebración del Centenario de la Revolución de Mayo porque es el encargado del orientar el pensamiento de la escuela y porque ésta representa el germen del alma nacional. (Ramos Mejía,1909)

El primero de los proyectos es erigir un monumento al maestro de escuela ${ }^{5}$, considerando que debe honrarse la memoria a los "servidores de la patria." Si bien no explicita en qué plaza de Buenos Aires se construirá, se dirigen cartas al Poder Ejecutivo Nacional, gobernadores, asociaciones y bancos para solicitar apoyo. El mismo Tomás Estrada es uno de los designados en las comisiones para su creación. Por otra parte, se solicita la autorización al Congreso de la Nación.

Otro de los proyectos que se detalla es la creación de un Museo Histórico Escolar donde se puntualizan cuáles serán los elementos de reproducción que lo constituyan. En el diagnóstico de situación se plantea que tal museo solamente "[...] existe en el nombre y en una leyenda del presupuesto". En el escrito se explica la necesidad de crearlo, proveerlo, organizarlo y darle la importancia que requiere" (Ramos Mejía, 1909, p. 22). La argumentación que sigue es más que interesante, Buenos Aires tiene museo escolar y la Nación no.

Allí se inserta igualmente la decisión de bautizar escuelas con el nombre de grandes hombres que dieron la indecencia a la república y a las damas argentinas por su loable patriotismo, así como también el Atlas escolar que formaba parte de esta política de formación ciudadana y que en general se estudió a partir del conocido informe ramos, donde se diagnosticaba la falta de apoyo de las provincias y la carencia de material cartográfico necesario a tales fines.

Elementos en común de los proyectos establecidos con el esquema de proceso estratégico de gobierno:

Se establece una necesidad o un objetivo claro; el debate del protagonismo de la escuela en el período del Centenario, con su consecuente del presupuesto y los recursos materiales para su ejecución, que no solamente se solicitan, sino que además se obtienen.

Se organizan comisiones ad hoc para la gestión de los proyectos, pero también para el acompañamiento en el funcionamiento a largo plazo.

Se explicitan cuáles serán las instituciones que aportarán recursos económicos y las erogaciones del erario público.

Por último, si bien los diferentes proyectos articulados persiguen en sí mismos objetivos propios, todos poseen un nivel de concreción material, a saber: un atlas, un monumento, un museo escolar, la ampliación de la sede del CNE, etc.

Para tomar un caso particular al interior de la fuente, puede leerse el Informe de Juan Pedro Ramos (1910) que fuera estudiado en forma fragmentaria como diagnóstico de la situación precaria de los materiales en las provincias. Si se enmarca en una matriz 5 El monumento se erige en 1931 en la forma de lo que hoy se conoce como Puerta Historiada en el Colegio Carlos Pellegrini (Conmemoración del Día del Maestro, 11 de Septiembre de 1933, Consejo Nacional de Educación). 
de estudio ampliada, este primer atlas argentino es parte de una política educativa del Centenario. El pedido de Ramos Mejía de confeccionar un Atlas Nacional tiene un objetivo que puede ser leído desde una perspectiva que supere el carácter meramente instrumental que se le atribuye. Es parte de los contenidos educativos que se prescriben. La introducción de mapas en los textos escolares son una muestra de ello.

\section{Consideraciones finales}

Si bien el trabajo de investigación queda aún abierto, es posible hacer algunas reflexiones en torno al proceso de estudio. Los aportes se complementan con nuevos interrogantes: por un lado, para seguir profundizando en el estudio de los antecedentes de las políticas educativas y abriendo, por el otro, la posibilidad de extrapolar esas preguntas ante la crisis de las políticas actuales. Cuando se observan las modificaciones del rol de estado, la pregunta surge por sus antecedentes. ¿Que había en el origen que generó las condiciones de posibilidad para que el estado planifique?

Para seguir avanzando, se requiere la desnaturalización de algunos modos de ser y hacer la escuela que las políticas educativas siguen imponiendo. Si bien este trabajo se inscribe en un estudio más amplio, cuyo objeto son las memorias de José María Ramos Mejía durante la presidencia del CNE, este entramado permite empezar a andar un camino donde la Historia de la Educación proporcione pistas intelectivas para afrontar los desafíos presentes y futuros. Este es el caso de mirar los antecedentes de la planificación en términos de las políticas públicas educativas, y los indicadores que propusieron sus redactores y ejecutores desde el Estado naciente.

No se debe perder de vista que el modelo que hoy está en crisis es el que se extendiera por más cien años. La crisis del modelo vigente de las políticas públicas que paradójicamente mantienen vivos los aportes de sus antecedentes en la construcción del estado no implica la demonización de esos programas, sino más bien la revalorización de su éxito. Lo que tampoco quiere decir que se debe volver al pasado, sino estudiar de él las acciones, ideologías y debates, visitando tiempos pretéritos en la recuperación de las claves de "éxito".

Respecto de la metodología empleada, se considera un aporte al análisis documental que permite revisar el origen y analizar las fuentes, los debates, las dificultades, aunque siempre es necesario reconocer los riesgos de poner en cetteris paribus las variables epocales. Por ello se considera relevante mantener la vigilancia sobre las variables contextuales que complementan la matriz metodológica.

Dentro de las primeras reflexiones, surge la evidente necesidad de estudiar los antecedentes de las políticas educativas, buscando diagnósticos sobre los problemas de la educación y las otras esferas del Estado comprometidas con estas transformaciones sustantivas. De los primeros tramos de interpretación surgen claras acciones concretas de las políticas estudiadas en relación a la claridad con que se diseñan y se siguen los proyectos formulados. Los diagnósticos de fracaso de las políticas educativas en la situación actual del sistema educativo, por un lado, y los diferencias de éxito del Programa de la Educación Patriótica, por el otro, desprenden la necesaria indagación de las políticas educativas. Desde este punto es posible estructurar indicadores de éxito en la implementación, sin perder de vista el escenario epocal.

Recuperando la perspectiva de la educación como derecho de Scioscioli (2015), pero situados en un enfoque eminentemente político, se fundamenta una educación que admite tanto la formulación, sanción e implementación de las leyes educacionales como 
Laura Guic/ Las políticas educativas en la Historia de la educación [...]/31

así también su supervisión y evaluación. El amplio desarrollo normativo referido e indagado por el autor cimenta el arco de normas en términos de políticas educacionales que configuraron modos de ser y de hacer en la escuela desde el gobierno de la educación.

Esta perspectiva, junto con los rasos que se pueden detectar en el presente, abre la posibilidad de construir un conocimiento que contribuya a una lectura diferente de las políticas educativas vigentes, para saber en el futuro cuánto de las estructuras o de la matriz fundacional pervive en el sedimento de las actuales políticas, y cómo pueden capitalizarse aquellos objetivos primigenios para la formulación de políticas que transformen la educación según las necesidades del presente crítico que habitamos. Porque, ciertamete, para conocer más en profundidad las políticas educativas, es conveniente entender cuáles eran los problemas a los que daban respuesta.

Para finalizar este trabajo, podemos recuperar la necesaria reflexión desde el origen, ya advertida por Juan Carlos Tedesco:

El primer desafío de la nueva gestión educativa consiste en crear una cultura de fuerte compromiso con la educación por parte del conjunto de la clase dirigente del país, como la que existió en la generación de 1880 . (Tedesco, 2005, p. 144)

\section{Bibliografía}

- Botana, N. (1987). El orden conservador. Buenos Aires: Editorial Sudamericana.

- Escudé, C. (1990). El fracaso del Proyecto Argentino. Educación e Ideología. Instituto Torcuato Di Tella, Buenos Aires.

-Fernández Lamarra, N. (2002). Veinte años de educación en la Argentina. Buenos Aires: EDUNTREF.

-Fernández Lamarra, N. (Coord.) (2003). Política, planeamiento y gestión de la educación. Modelos de simulación en Argentina, Buenos Aires: EDUNTREF.

-Fernández Lamarra, N. (2006). "Reflexiones sobre la planificación de la educación en la Argentina y en América Latina. Evolución, crisis, desafíos y perspectivas". En Fernández Lamarra, N. (Comp.). Política, Planeamiento y Gestión de la Educación. Modelos de simulación en Argentina. Caseros: EDUNTREF.

-Fernández Lamarra, N. (Comp.) (2009). Universidad, Sociedad e Innovación. Una perspectiva internacional. Buenos Aires: EDUNTREF.

-Fernández Lamarra, N. (2010). Hacia una nueva agenda de la educación superior en América Latina. México D. F: ANUIES.

—Fernández Lamarra, N. y De Paula, M. F (Comp.) (2011). Democratización de la educación superior en América Latina. Buenos Aires: EDUNTREF.

—Fernández Lamarra, N. y Aiello, M. (2012). "Planificación estratégica y evaluación para la mejora. El impacto de las evaluaciones institucionales en la planificación estratégica y en la gestión de las universidades argentinas". Disponible en: http:// www.fvet.edu.uy/drupal-6.16/sites/default/files/La\%20Planificacion\%20estrategica $\% 20$ en $\% 20$ las\%20instituciones\%20de\%20educacion\%20superior.pdf

—Fernández Lamarra, N. y Coppola, N. (2014). "Desafíos para la construcción del Espacio Latinoamericano de Educación Superior, en el marco de las políticas 
supranacionales". Journal of Supranational Policies of Education, (1), pp. 67-82.

—Guic, L. (2016). "El gobierno del Otro". En Actas del VIII Jornadas de Historia del Bicentenario. Evocación y reflexiones. Buenos Aires: Fundación para el Pensamiento Argentino e Iberoamericano, pp. 161-169.

- Herrero, A. (2010). "Una aproximación a la historia de la educación argentina entre 1962 y 1930, en los niveles primario y secundario" (pp. 37-92). En La Universidad en la Argentina. Remedios de Escalada: EDUNLa.

—Marengo, R. (1991). "Estructuración y consolidación del poder normalizador. El Consejo Nacional de Educación”. En Puigrós, A. (Dir.). Historia de la Educación Argentin, Tomo III: Sociedad Civil y Estado en los orígenes del Sistema educativo (pp. 48-71). Buenos Aires: Galerna.

-Matus, C. (1992). Politica, Planificación y Gobierno. Caracas: Fundación Altadir.

-Muzzopapa, H. (2015). Educación y trabajo en el orden conservador. Ideas alberdianas y vanguardia normalista. Buenos Aires: Biblos-EDUNLa.

-OEI (2010). "Metas 2021. La educación que queremos para la generación de los Bicentenarios". Buenos Aires: OEI. Disponible en www.oei.es/metas2021/todo.pdf

—Oszlak, O. (1990). "Políticas públicas y regímenes políticos: reflexiones a partir de algunas experiencias latinoamericanas". Estudios del CEDES, 3 (2).

—Pérez Centeno, C. y Leal, M. (2011). “¿Han funcionado las reformas educativas en América Latina? Los casos de Argentina, Brasil y Chile”. Educational Policies Analysis Archives, 19, (36).

—Puelles Benítez y De Urzúa, R. (1996). "Educación, gobernabilidad democrática y gobernabilidad de los sistemas educativos". Revista Iberoamericana de Educación, (12).

-Ruiz, G. (2016). La educación secundaria obligatoria en el marco de las reformas educativas nacionales. Regulaciones federales y politicas jurisdiccionales. Buenos Aires: EUDEBA.

-Scioscioli, S. (2015). La educación básica como derecho fundamental. Implicancias y alcances en el contexto de un Estado federal. Buenos Aires: EUDEBA.

-Tedesco, J. C. y Tenti Fanfani, E. (2004). Las reformas educativas en la década de 1990. Un estudio comparado de Argentina, Chile y Uruguay. Buenos Aires: BID.

-Tedesco, J. C. (2005). Educación y sociedad en la Argentina (1880-1945). Buenos Aires: Siglo XXI.

\section{Fuentes}

—Ramos Mejía, J. M. (1909). La escuela del Centenario. Buenos Aires. Consejo Nacional de Educación.

—Ramos Mejía, J. M. (1899). Las multitudes argentinas. Buenoes Aires. :Editorial Belgrano.

—Ley N ${ }^{\circ} 4874$. "Sobre Escuelas Nacionales en las Provincias" (1905).

—Ley N 1420. "Educación común y Decreto reglamentario" (1884). 


\title{
Ciencia económica y valores ${ }^{6}$ Riquezas y Fortunas
}

\author{
Diego Guichòn ${ }^{7}$ \\ dieguichon@gmail.com \\ Rec.15/08/17, Apr.23/09/17
}

\section{Resumen}

En el campo de la economía, la teoría económica clásica y neoclásica propusieron distinguir en su interior una rama científica o positiva y otra denominada arte, práctica, o enfoque normativo, donde, sólo en este último tendrían cabida valores no epistémicos. Este trabajo investiga dos mecanismos por los cuales, valores no epistémicos influyen sobre el contenido de la disciplina considerada como ciencia o economía positiva. El primero es que cambio en estos valores modifica el contenido de la ciencia positiva, haciendo que determinadas prácticas o medios sean estudiados o no, o bien que se estudien determinados aspectos de los mismos y otros no se estudien. El método científico, aun cuando pudiera consensuarse cual es específicamente para la ciencia económica, no podría influir sobre este tipo de cambio científico. En segundo lugar, se encuentra la introducción de juicios de valor en la parcialidad de las teorías o de la evidencia empírica considerada. Para ilustrar ambos mecanismos se estudia un caso histórico, sobre cómo ha sido tratado un objetivo, el hacerse rico, y los medios para lograrlo.

Palabras clave: ciencia - valores - teoría económica - riqueza.

\section{Summary}

In the field of economics, classical and neodlassical economic theory, they proposed to distinguish within them a scientific or positive branch and another called art, practice, or normative approach, where only non-epistemic values would fit in the latter. This work investigates two mechanisms by which non-epistemic values influence the content of the discipline considered as pos-

6 El presente trabajo se realizó en el marco del Proyecto "Universidad y educación en valores. La construcción de un marco axiológico para la formación ético-epistémica de los profesionales", dirigido por la Profesora Silvia Rivera. Agradezco los comentarios de la Profesora Silvia Rivera y la Licenciada Paula Alzieu. Agradezco también particularmente los comentarios del Dr. Ricardo Borrello. Por supuesto que los errores y omisiones que perduren en este trabajo son de mi exclusiva responsabilidad.

7 Licenciado en Economía y Magister en Metodología del a Investigación Científica, Universidad Nacional de Lanús. 
itive science or economy. The first is that change in these values modifies the content of positive science, causing certain practices or means to be studied or not, or to study certain aspects of them and others not studied. The scientific method, even if it could be agreed upon specifically for economic science, could not influence this type of scientific change. Second, there is the introduction of value judgments in the bias of theories or the empirical evidence considered.

To illustrate both mechanisms, a historical case is being studied, on how an objective has been treated, how to become rich, and the means to achieve it.

Key words: science - values - economy theory - wealth.

\section{Ciencia y valores}

Considerar la ciencia como una actividad implica que se tomen permanentemente decisiones, tales como: ¿qué fenómeno estudiar y cuál no estudiar?, ¿qué termino emplear y cómo definirlo?, ¿qué teoría emplear y cuál descartar?, ¿qué integra y qué no integra la base empírica?, ¿qué resultado es relevante y cuál no lo es?, ¿qué es digno de publicarse y qué producto no reúne estas condiciones?

Respecto de la decisión sobre el fenómeno estudiar, desde al menos Max Weber y en adelante existe un amplio consenso de que en esta elección pueden intervenir juicios de valor no epistémicos, de tipo sociales o políticos. La decisión de cuándo aceptar o rechazar una teoría, fue sobre la cual se basó la epistemología de tipo positivista y realista de la primera mitad del siglo XX. Se consideró que el contexto en que se tomaba esta decisión, el de justificación, podía aislarse del resto de los contextos. Inicialmente se trató de justificar estas decisiones como formas de búsqueda o aproximación a la verdad. Posteriormente, se tomó conciencia de que en muchas circunstancias se carecía de medios suficientes para ese objetivo. Se apeló entonces a una serie de valores, a los cuales se denominó epistémicos o cognitivos, como propios de la ciencia, incluyendo no solo la verdad, sino la verosimilitud, precisión, fecundidad, coherencia, amplitud, simpleza, capacidad explicativa, etc. Por ejemplo, en ocasiones, al momento de seleccionar dos teorías alternativas cuyo valor de verdad no se conoce, puede prevalecer en la elección otro valor epistémico, y seleccionarse la que es más simple ${ }^{8}$. Este tipo de valores fue incorporado con poca controversia por las corrientes positivistas y realistas? ${ }^{9}$. En general no se observa que se acuse a un filósofo de tener una visión irracionalista de la ciencia por recurrir a valores epistémicos para fundamentar las decisiones, incluyendo otros distintos del de la búsqueda de la verdad. En la medida que los valores epistémicos se suponen compartidos, no se plantearían controversias. La visión opuesta existe respecto de los valores no epistémicos, tales como las consideraciones políticas y sociales donde sí podrían existir distintas opiniones, sin que existiese un procedimiento claro para unificar criterios. Este marco se vio sin embargo conmovido por estudios de historia de la ciencia, y posteriormente de filosofía del conocimiento científico, los cuales sugerían que lo ocurrido efectivamente en la práctica no podía explicarse solamente recurriendo

\footnotetext{
8 La orientación a complementar la evidencia empírica con juicios de valor epistémicos se encuentra en los escritos de Thomas Kuhn posteriores a la Estructura de las Revoluciones Científicas. Ver Guerrero Pino (2000). El autor que toma y desarrolla esta reflexión es Laudan (1984).
}

9 Nos referimos particularmente al realismo de Popper. 
a la lógica, la base empírica y los valores epistémicos. ${ }^{1}$ De acuerdo a los mismos, habría existido un conjunto diferente de prácticas, convenciones y valores que habría influido en las decisiones. Dentro de los valores se incluyen los del tipo epistémicos y otros de tipo social y político. La discusión sobre estos tópicos continúa aún.

\section{Ciencia económica y valores}

En la ciencia económica se da un caso particular, que no se observa en las ciencias naturales. Tomada en su conjunto, es difícil encontrar una corriente de pensamiento que afirme que excluye en sus teorías toda consideración de valores no epistémicos, pero sí existe una tendencia a pensar que puede separarse dentro de la ciencia una rama estrictamente científica o positiva, de otra política, normativa o práctica. Es decir, si bien existirían valores no epistémicos incorporados, los mismos estarían identificados y confinados al ámbito político, normativo o práctico de la disciplina, sin afectar a la rama científica o positiva, que indicaría cuándo aceptar o rechazar una teoría. Veamos algunos ejemplos.

La economía clásica, por lo menos a partir John Stuart Mill, comenzó a distinguir entre ciencia y arte e intentó destacar la neutralidad valorativa de la primera, sosteniendo que la misma no trataría sobre fines u objetivos cuya valoración sería extra-científica, mientras que el arte sí lo haría (Stuart Mill, 1997; Crespo, 1997)². Sin embargo, tal como señala Hutchison, cada autor importante, incluyendo al propio Mill, propuso uno o varios objetivos no epistémicos principales para la teoría economía, que no necesariamente coincidieron entre sí.

Para Adam Smith, el objetivo central fue la libertad económica como parte de un sistema más amplio de libertad natural. Para Jeremy Bentham, fueron cuatro objetivos, la subsistencia, la seguridad, la abundancia y la igualdad. En el caso de David Ricardo, fue el objetivo de la máxima producción, mientras que, para John Stuart Mill, un objetivo prioritario era obtener una mejor distribución de la riqueza (Hutchison, 1971).

La denominada "economía neoclásica" o corriente principal o "mainstream", que se desarrolló posteriormente, hizo un lugar común el afirmar, en renombrados estudios metodológicos ${ }^{3}$, que puede distinguirse una ciencia positiva, valorativamente neutral, y un enfoque normativo, donde sólo en la última se introducirían juicios de valor ${ }^{4}$. Este

1 En este sentido sobresale el trabajo de Khun, sobre la Estructura de las Revoluciones Científica (1971)

2 John Neville Keynes, padre de John Maynard Keynes, señaló que la economía debía dividirse en tres ramas: "[...]una ciencia positiva[...], un cuerpo de conocimiento sistematizado concerniente a lo que es; y una ciencia normativa u ordenadora[...], un cuerpo de conocimiento sistematizado que discute los criterios sobre lo que debe ser; un arte[...], un sistema de reglas para la consecución de un fin dado." (Keynes, 1891, pp. 34-35 y 46.).

3 Lionel Robbins, economista de la escuela austriaca, defendió esta distinción en su obra de 1932. Milton Friedman lo hizo a su vez en un influyente ensayo de 1953, donde señala: "La economía positiva es en principio independiente de cualquier posición ética particular o de juicios normativos".

4 Esta escuela de pensamiento se generó inicialmente a partir de principios de la ética utilitaria, y luego por los desarrollos propios basados en los conceptos de curva de indiferencia y principios de compensación, un conjunto de criterios para realizar recomendaciones prácticas basadas en un enfoque positivo de la economía. Esta posibilidad se desarrolló dentro de la denominada "nueva economía del bienestar". Su característica principal, a nuestro juicio, es la separación entre un análisis de eficiencia y un análisis de equidad, mientras el primero se referiría a cómo cambia la suma total de excedentes de la economía, y sería propio del enfoque positivo, el segundo se referiría a cómo se distribuye estos excedentes, y sería propio del enfoque normativo. En este marco, el economista neoclásico podría hacer 
enfoque se encuentra incorporado en los libros de texto con que se enseña la teoría económica en cursos introductorios, y en libros avanzados de teoría económica. ${ }^{56}$

En síntesis, el pensamiento económico, clásico y neoclásico, incluye dentro de lo que se considera arte, o rama normativa, el reconocimiento de valores no epistémicos. Una diferencia entre ambas corrientes es que los primeros proponían explícitamente sus valores no epistémicos, mientras que los últimos, intentan presentarlos como juicios adoptados fuera de la disciplina ${ }^{7}$.

Ahora cabe preguntarse si la aspiración de estas corrientes de pensamiento de identificar y de alguna forma controlar los juicios de valor no epistémicos conque trabaja, para evitar que los mismos afecten la economía como ciencia positiva, puede cumplirse o bien si se ha cumplido. Sin pretender realizar un análisis exhaustivo, podemos mencionar la opinión de algunos autores.

Gunnard Myrdal en un libro publicado inicialmente en 1928 argumentó con diversos ejemplos, que, tanto en la economía clásica como en la neoclásica, aun dentro del enfoque denominado científico o positivo, incorporaron implícitamente juicios de valor, aunque no hayan sido explícitamente reconocidos (Myrdal, 1953). Si bien inicialmente la posición de Myrdal es que esto había ocurrido, pero podía cambiarse, en un escrito posterior lo considero ya como inevitable.

Schumpeter, un autor al cual nos referiremos posteriormente, sostuvo que las teorías económicas en su etapa inicial están cargadas con la visión o ideología de sus creadores, pero que los errores ideológicos tienden a corregirse con el método científico ${ }^{8}$, aunque esto puede ser un proceso lento. Como la introducción de nuevas teorías es un proceso continuo, nunca se podrá asegurar que en un momento determinado la ciencia esté libre de prejuicios ideológicos?.

Hutchinson (1971), propone su propia división de la actividad científica en tres etapas la pre científica, científica y post científica. Para este autor hay juicios de valor, como la importancia del tema a estudiar, que son inevitables en cualquier ciencia, pero respecto de los juicios de valor implícitos en la explicación teórica y en la evidencia empíricas considerada, considera al igual que Schumpeter que la aplicación del método científico permitirá eliminarlas en el tiempo.

recomendaciones basado en criterios de eficiencia, pero se abstendría de emitir juicios de valor sobre la forma más equitativa de distribución. Un texto clave en que se introduce esta distinción es Hicks (1939), un enfoque más pragmático y reciente puede encontrarse en Haberger (1971). Little (1951) ha criticado esta visión, y sostiene que es imposible desarrollar una economía del bienestar sin que sea al mismo tiempo descriptiva y prescriptiva.

5 Ver libros de texo como Makiw (2002) que señala: "Las afirmaciones positivas, son descriptivas. Se refieren a cómo es el mundo. Las afirmaciones normativas son prescriptivas. Se refieren a cómo debería ser el mundo (p. 20). Salmuelson y Nordhaus (2006) afirman: "la economía positiva describe los hechos de una economía, mientras que la normativa se refiere a los juicios de valor" (p. 7). Ver también Nicholson (2001).

6 Una reseña sobre el debate epistemológico de la cuestión puede encontrarse en Wilbur Charles K., y Hobskergen Roland (1998).

7 Por ejemplo, cuando se trata de juicios sobre equidad en distribución del ingreso.

8 En rigor, Schumpeter (1971) habla de "análisis" y no de método, e incluye dentro del mismo, historia, estadística y teoría.

9 Ver la exposición y citas que Hutchison (1971) hace sobre las ideas de Schumpeter. 
En síntesis, mientras que para Myrdal la separación de juicios de valor de la economía como ciencia no se ha producido, y sería imposible que se dé, para autores como Schumpeter y Hutchinson, en el desarrollo de la economía como ciencia se introducen juicios de valor no epistémicos, pero, merced al método científico, los mismos son gradualmente eliminados. La confianza en el método científico para eliminar juicios de valor no epistémicos, al menos en el largo plazo, contrasta con las dificultades para consensuar cuál es ese método dentro del pensamiento económico. En tal sentido, cabe mencionar que la ciencia económica ha tenido particulares dificultades para ajustarse a los cánones metodológicos del positivismo o del realismo en la versión de Popper. En particular ha sido cuestionada la falta de realismo de sus supuestos, ${ }^{10}$ la imposibilidad de falsear los mismos ${ }^{11}$, y las dificultades de contrastar sus predicciones ${ }^{12}$. En la década del ochenta, diversos autores cuestionaron, sobre estas bases, el carácter científico de la economía neoclásica. Este debate no aún ha terminado ${ }^{13}$.

\section{Nuestro trabajo}

Partimos de la premisa de que la ciencia, en general, no avanza en todas las direcciones simultáneamente, sino que su desarrollo en un momento determinado refleja las prioridades sociales económicas y políticas que existieron en el pasado sobre lo que fue importante estudiar y lo que no lo fue. En tal sentido, la ciencia no existe antes o independientemente de los juicios de valor no epistémicos, sino que es una respuesta a los interrogantes que plantean estos valores. ${ }^{14}$

Este trabajo describe algunos de los mecanismos por los cuales los valores no epistémicos, emergentes de un determinado contexto histórico, influyeron en el pasado en la constitución del objeto de la economía considerada como ciencia o como economía positiva.

El primero de estos mecanismos es la relación entre los fines socialmente valorados y los medios legítimos para lograrlos. La economía siempre ha estudiado la relación entre

10 Milton Friedman (1953) ha reconocido este hecho y ha abandonado la explicación y enfatizado la predicción a partir de una visión instrumentalista. Ver también Marqués (2004) y Borrello (2006).

11 Karl Popper, un autor caracterizado por su insistencia en la contrastación empírica, ha adoptado, respecto de la economía, una metodología ad hoc que incluye supuestos no contrastables, denominada "lógica de la situación". Esta propuesta está presentada en varios trabajos, incluyendo La Sociedad abierta y sus enemigos y Pobreza del Historicismo. Ver Marqués (2004) y Gómez (1995) para un enfoque crítico. Una importante tradición de pensamiento denominada escuela Austríaca, a la cual pertenecen Von Mises y Hayek, ha renunciado al positivismo y defiende un método racional a priori, no contrastable con la experiencia empírica (Marqués, 2004). En esta corriente es dable observar un método hermenéutico, pero sin "círculo hermenéutico", o sea un método que se supone permite acceder mediante la comprensión a verdades válidas en todo tiempo y lugar, y no a un proceso que parte de interpretaciones, para dar lugar a nuevas interpretaciones, sin que se alcance un punto final en este proceso (Zanotti, 2011).

12 Cabe mencionar el trabajo pionero de Hutchinson (1938), quien señaló, desde un punto de vista falsacionista, la escasa contrastación empírica que se realizaba de las teorías económicas. Ver Márqués (2004).

13 Mario Bunge ha descalificado a la teoría económica neoclásica como ciencia, y la ha catalogado como una seudociencia o semi-ciencia (Bunge: 1985). Por su parte, D. McCloskey inicia en la misma década la corriente epistemológica, que caracteriza a la ciencia economía como un ejercicio de retórica.

14 Esta idea se contrapone a la idea de Walras sobre la existencia previa de una teoría económica "pura", tal como menciona Borrello (2006). 
medios y fines y, siempre que se ha propuesto un fin como socialmente valioso, el contenido de la ciencia ha incluido al menos un medio legítimo para lograrlo. De manera que al cambiar los valores no epistémicos que se plantean como objetivos prioritarios, ha cambiado el contenido de la economía científica o positiva, incluyendo al menos el estudio de algún medio para alcanzar dicho fin.

Un ejemplo preliminar nos lo brinda el cambio de objetivos dentro de los economistas clásicos. John Stuart Mill, al incluir como objetivo la mejor distribución de la riqueza, tuvo que incluir dentro de la ciencia económica al menos un medio que permitiese alcanzar este objetivo, en este caso fue una política impositiva con tasas progresivas sobre el valor de los bienes transmitidos por herencia. A partir de ese momento, la ciencia económica comenzó a estudiar este y otros mecanismos para modificar la distribución del ingreso. Esto no habría sido posible para Adam Smith, pues su objetivo social prioritario no era compatible con el de Mill, dado que priorizaba la protección de la propiedad privada por sobre el objetivo distributivo (Hutchinson, 1971; Pardo Beltran, 2000; Schwartz, 1968) 15 .

En este trabajo se analizará un ejemplo inverso, en el cual un fin considerado inicialmente como socialmente valioso es luego omitido. Esto repercute en la ciencia económica, donde los medios que inicialmente fueron estudiados para obtener dicho fin son luego omitidos o bien tratados por su contribución a la realización de los nuevos valores no epistémicos que pasan a orientar la disciplina. De esta manera cambia el contenido de la ciencia económica, y adicionalmente cambia la valoración dentro de la disciplina de un mismo medio.

El ejemplo analizado corresponde a un fin particular, hacerse personalmente rico a partir de la propia actividad; o sea, acumular importantes riquezas personales en el período de tiempo que dura una vida, y los medios son por supuesto todos aquellos que permitirían alcanzar este fin. El término "rico" es impreciso, en este trabajo alude a montos de riqueza material o intangible, que sólo una muy pequeña fracción de la sociedad puede poseer. No podemos mencionar rangos de valores porque tal vez una familia con un determinado patrimonio pueda ser considerada muy rica en una etapa histórica y deje de serlo, aún manteniendo ese patrimonio, en otra etapa. En términos sociales, se trata siempre de una élite.

Este caso ejemplificará cómo, en la economía considerada como ciencia positiva, se privilegian la teorización y la observación de ciertas prácticas y no otras, destacando ciertos atributos de estas prácticas y omitiendo otros; lo cual está directamente influido por juicios de valor sobre aquello que la teoría normativa considera como socialmente valioso.

El segundo mecanismo de introducción de juicios de valor ha sido mencionado por Hutchinson (1971), y se refiere a la parcialidad de las teorías y de la evidencia empírica considerada. Lo que se hará en alguna medida es aplicar las ideas de Schumpeter sobre la carga ideológica de las nuevas teorías a las teorías económicas que él mismo formuló respecto de la actividad empresarial. Todo esto siempre vinculado al caso que vertebra este trabajo, esto es: el objetivo de hacerse rico personalmente y los medios para lograrlo.

Nuestro análisis explicita, en este caso, una forma práctica de identificar estas situaciones, a partir del siguiente supuesto ontológico. Toda realidad económica es compleja

15 Sin perjuicio de esto, cabe señalar que Adam Smith criticó una institución particular de los derechos de sucesión como fue la primogenitura, es decir, el derecho del hijo mayor a quedarse con la posesión de los campos de su padre, pero lo hizo por motivos distintos, no en función de que esos bienes fueran confiscados, sino que se integraran más plenamente al comercio (Borrello, 2008).

16 En otras políticas tales como la posición frente al sindicalismo, la posición de Mill fue variando en el tiempo; lo mismo ocurrió con respecto a la cooperación (Schwartz, 1968). 
y está compuesta por una mezcla de prácticas con diversa valoración social, algunas consideradas más valiosas que otras, y algunas consideradas como disvaliosas. Si bien no podemos conocer todos las prácticas posibles, ni la proporción en que participan cada una en la vida social, sí podremos suponer que una teoría "positiva" (que sólo se refiera a comportamientos socialmente valiosos) tendrá un sesgo valorativo positivo. De igual forma que tendrá un sesgo valorativo inverso una teoría "positiva" que, para representar una realidad económica compleja, sólo haga mención a comportamientos socialmente disvaliosos. En este marco, se puede identificar el sesgo de las explicaciones parciales si sólo se seleccionan, en las mismas, comportamientos socialmente valiosos o socialmente disvaliosos.

\section{La reflexión ética sobre la acumulación de riquezas personales}

Antes de la propuesta de John Stuart Mill, de no incluir el estudio de los fines dentro de la ciencia económica positiva, se dio una interesante discusión ética sobre el fin de acumular grandes riquezas personales.

Aristóteles recoge una diferencia existente en su tiempo entre dos términos: "crematística" y "oikonomía", donde el primero se refiere a la "actividad" adquisitiva por sí misma, y la segunda la administración de la casa. Con base en su teoría ética sobre los valores y formas de vida, descarta la crematística como algo natural, cuando trata la adquisición de bienes materiales como un fin en sí mismo, y no como un medio para alcanzar lo realmente valioso en la vida. Se observa, ya en este antecedente una tendencia a separar, del campo de la economía, el estudio de la acumulación de riquezas personales por sí mismas, fundando esto en razones éticas y considerándolo como un comportamiento "antinatural".

La acumulación de riquezas personales como un fin en sí mismo vuelve con fuerza en los orígenes del capitalismo. El pensamiento mercantilista, que para muchos autores es "pre-científico", incluía como una preocupación principal el estudio de las formas más adecuadas de acumular riquezas personales, tanto para los monarcas como para los comerciantes. ${ }^{17}{ }^{18}$ En el caso de los monarcas, se mencionaba una justificación ética para esta acumulación, y es que se trataba de un medio para fines de defensa. El monarca que tuviese un tesoro menor que sus rivales estaría expuesto a la acción agresiva de ellos. Este mismo argumento podía invertirse, y señalar que el monarca con mayor tesoro podría agredir a sus vecinos con mayor probabilidad de éxito ${ }^{19}$.

17 Desde un punto vista funcionalista, el dinero permitía pasar de una economía natural a una mercantil. Pero desde el punto de vista de los actores, el énfasis de esta corriente de pensamiento en la acumulación de metales preciosos deriva de su preocupación por la acumulación de riquezas personales, donde se privilegiaban algunas características del oro y la plata (como la densidad de valor por unidad de volumen) que facilitaba el transporte, almacenamiento y defensa de masas de riqueza. En tal sentido, el dinero metálico resultaba más fácil de defender que las grandes extensiones de tierra y otros bienes durables de la época, como barcos o mercaderías no perecederas. Por otra parte, los metales podían acumularse durante grandes periodos de tiempo para formar grandes riquezas, a diferencia de otras mercaderías perecederas como granos o animales. Desde un punto vista funcionalista, el dinero permitía pasar de una economía natural a una mercantil.

18 La principal obra de Tomas Mun, un destacado mercantilista, fue publicada originalmente en 1664 y llevó como titulo "El Tesoro de Inglaterra por el Comercio Exterior" (Mun, 1954).

19 Ver sobre este punto la cita que realiza Heckscher (1943) de von Hôrnigk y de John Locke (pp. 468 y 469). Smith relativiza este argumento en la Riqueza de las Naciones (1987, p. 388). 
Adam Smith, antes de publicar su obra conocida como La Riqueza de las Naciones, publicó su Teoría de los Sentimientos Morales, obra sumamente interesante para el objeto este trabajo. En esta obra ya propuso la teoría de la "mano invisible" para argumentar que el consumo de los ricos no hace daño a la sociedad, sino que, al contrario, es compatible con el bien común gracias a una suerte de armonía pre-establecida. En Adam Smith, como antes en Mandeville ${ }^{20}$, la reflexión sobre las personas ricas se orienta a su forma de vida y pautas de consumo, antes que a los medios para lograr esta posición. Por otra parte, en su capítulo I de la Parte IV de dicha obra, el autor hace una extensa referencia a que aquellas personas que siendo de origen humilde ponen como objetivo de su vida el acumular riquezas y llegar a ser ricos. Sobre el final de sus años, señala este autor, contemplan que en realidad los esfuerzos realizados no han valido la pena. En este último caso, se observa nuevamente que Adam Smith critica el objetivo de buscar las riquezas por las riquezas mismas, basándose en consideraciones éticas relativas a los objetivos que valdría la pena buscar en la vida (Smith, 1987).

\section{Riquezas personales, economía clásica y neoclásica}

\section{V.1. La acumulación de grandes riquezas personales y McCloskey}

Es interesante observar cómo, en la conciencia de los economistas modernos, no está claro el momento y la forma en que se ahondó el estudio de la acumulación de grandes riquesas personales en su disciplina.

Fox (2011) cita en su libro sobre el Mercado de Capitales la siguiente anécdota. Un economista que investigaba el funcionamiento del mercado de capitales se encuentra, en la década del sesenta, por dar una conferencia y, al ser presentado por un operador del mercado de capitales de Nueva York, este último lo introduce con una frase estándar que refiere claramente a una grieta entre el mundo académico y el mundo de los negocios. "If you're so Smart, why aren't you rich?". El sentido de la pregunta, en el contexto en que se formula, se refiere a si los buenos economistas están en una mejor posición, gracias a su saber, para acumular grandes riquezas personales. ${ }^{21}$

McCloskey (1985 y 1990) toma el desafío de contestar esta pregunta, interpretando "smart" como equivalente a "inteligente" o "científicamente preparado" y concluye que el hecho de que los economistas profesionales no logren, por su formación, hacerse ricos rápidamente, prueba la incapacidad predictiva y el carácter retórico de la economía.

Sin embargo, esta interpretación no agota el sentido del dicho popular. Se debe tener en cuenta que el significado de la palabra "smart" no es equivalente a la palabra "inteligent". El término "smart" es un término extremadamente amplio, del cual, siguiendo a Wittgestein, se podría decir que entra en múltiples juegos de lenguaje y múltiples formas de vida en cada uno de los cuales puede tomar un significado diferente (Rivera, 1994). Una traducción adecuada de una persona "smart" es la de una persona "lista"; o bien, usando un argentinismo, una persona "piola". O sea, la expresión se podría traducir:

20 Nos referimos al poema publicado por dicho autor en 1705, denominado "La fábula de las abejas, o vicios privados, beneficios públicos".

21 Por supuesto que la distinción entre riqueza por transferencia y por acumulación personal, no debe considerarse una dicotomía, en donde los casos de riquezas originados en la transferencia son totalmente distintos de aquellos realizados originados en la acumulación personal. En muchos casos se puede dar un proceso secuencial, de transferencia y acumulación. 
¿si usted es tan listo, por qué no es rico? En este sentido, de reducirse el significado del término "smart" al empleo de medios socialmente aceptables, tales como la inteligencia y la capacitación, se omitirían otras posibilidades que suelen ser objeto de reproche social, tales como el empleo de la astucia o el engaño. 22

Por otra parte, McCloskey, al referirse a las insuficiencias de la ciencia económica, ha referido su trabajo particularmente a la escuela neoclásica o "maistream". Este punto, para nosotros, muestra un error de apreciación, dado que esta corriente de pensamiento se originó en la escuela clásica, la cual, como trataremos de fundamentar, ya había excluido este objeto de su disciplina.

\section{V.2. Economía clásica y neoclásica}

Existen posiciones diversas sobre la continuidad o discontinuidad del pensamiento de Adam Smith entre su Teoría de los Sentimientos Morales y la Naturaleza de la Riqueza de las Naciones (Borrello: 2008). Pero es en la segunda obra donde Adam Smith planteó que el objeto de la economía como disciplina científica debía ser la riqueza de las naciones, y no la riqueza de los individuos, sosteniendo también que el estudio de la forma en que las personas acumulan riquezas personales no es un camino válido para explicar la riqueza de las naciones ${ }^{23}$. Señala Adam Smith que:

Los comerciantes conocen perfectamente de qué manera el comercio los enriquece, pues ese es su oficio, pero no forma parte de su profesión saber en qué forma enriquece a la nación. (Smith, 1987, p. 382)

Esta argumentación debe ser observada cuidadosamente. Lo que hace Adam Smith es substraer del objeto de estudio de la economía un fenómeno (la riqueza de los individuos), con la argumentación de que no permite explicar adecuadamente otro fenómeno (la riqueza de las naciones). Pero la acumulación de riquezas personales podría ser perfectamente un objeto de estudio en sí mismo, y, en efecto, era y sigue siendo un objeto de interés de gran parte de la población. Desde este punto de vista, se considera que Smith expande el objeto de estudio de la economía en una dirección para contraerlo en otra. Es decir, hace una selección sobre qué es importante estudiar y qué no lo es.

Por otra parte, el enfoque de su trabajo, y la importancia que le da a la teoría de los precios, tiene un resultado interesante. Podría pensarse que Adam Smith, en la medida que consideró al egoísmo como un móvil importante de la conducta económica humana y, junto con esto, la búsqueda de beneficios, consideraba indirectamente al proceso de acumulación de riquezas personales. Pero, por su propio enfoque, no podía explicar cómo un número reducido de personas se podía hacer mucho más rico que el resto, en base a su propia actividad.

La acumulación de grandes riquezas personales es un fenómeno altamente selectivo, mientras que los precios son fenómenos masivos, que afectan a todos los que participan de un mercado. Por ejemplo, la teoría sobre el funcionamiento del mercado de trabajo puede contribuir a explicar la pobreza, que es un fenómeno masivo, pero la teoría sobre la tasa de interés o del beneficio de mercado no podía explicar la rápida acumulación de grandes fortunas de un pequeño grupo de individuos.

22 Merton (1964) efectúa una larga cita de un texto Dickens, donde el término "smart", traducido como "listo" sugiere una persona inescrupulosa en la búsqueda de sus objetivos.

23 La crítica de Adam Smith al Mercantilismo se encuentra en el Parte IV de La Riqueza de las Naciones. 
Es decir, la economía clásica podía explicar la renta ordinaria para distintos tipos de tierra, y la remuneración ordinaria que percibiría el capital como beneficios, o los trabajadores como salario. Pero si una persona se hace más rico que el resto, entonces debe haber o bien una forma en que perciba rentas unitarias por su tierra mayores que la renta ordinaria, o bien una tasa de beneficio mayor por su capital que la habitual, o bien un salario muy superior al de mercado por su trabajo. O sea, una vez que la gran riqueza personal estaba constituida, se llegaba a explicar la remuneración ordinaria que podría percibir, pero no cómo se constituían estas grandes riquezas personales en corto periodos de tiempo a partir de aquellas remuneraciones ordinarias.

Hay asimismo ciertos medios para hacerse rico que fueron excluidos o cuestionados por Adam Smith. Podemos ilustrar esto con otra idea central sobre el comercio y la riqueza de los que participan en el mismo. Los mercantilistas habían señalado que en el comercio lo que gana una parte la pierde la otra parte, o sea que en el comercio no hay ganancia neta (Heckscher, 1943). Smith critica esta conclusión, señalando que las partes que participan voluntariamente en el comercio siempre ganan. Su interpretación deja afuera otras posibilidades, tales como el regateo, y un medio que durante el mercantilismo estuvo vinculado al comercio, que es la violencia. La actividad comercial mercantilista implicaba tanto mercaderías, barcos, tripulaciones, como también armas, fortificaciones, mercenarios o soldados. La idea de que el comercio es siempre voluntario deja fuera del objeto de la economía los casos en los cuales el esfuerzo bélico es parte de un negocio global ${ }^{24}$, y en donde también se pueden calcular costos, ingresos, beneficios, etc, y por supuesto la violencia asociada a la esclavitud ${ }^{25}$. Otro medio para hacerse rico en poco tiempo eran los monopolios, particularmente en el comercio. Estos medios fueron duramente cuestionados por la escuela clásica, dada su incidencia negativa sobre el libre comercio, como parte del sistema de libertad natural, y por su origen en cierta forma arbitrario originado en regulaciones y privilegios otorgados por las distintas formas de gobierno.

Realizar un análisis completo de la literatura producida por los economistas clásicos sobre las fortunas personales escapa al alcance de este trabajo; no obstante, podemos realizar algunas menciones, y observar cómo incluso la herencia como medio de adquirirla fue objetada.

Parece en este punto oportuno proponer una distinción entre fortuna y riqueza. Se utilizará el término "fortuna" para referirse a una forma particular de lograr una importante riqueza personal, que es la buena suerte. En su famoso libro Principles of Political Economy, de 1848, John Stuart Mill argumentó que la herencia debía eliminarse y que ningún miembro de la familia debería heredar más que una modesta suma, dado que este tipo de riqueza no se originaba en las cualidades de la persona, sino en su suerte ${ }^{26}$. Esta crítica está también presente en uno de los últimos grandes economistas clásicos, Edwin Cannan (1922), porque alteraría en base a la suerte la igualdad de oportunidades ${ }^{27}$.

24 Ya Aristóteles, en su obra Política (2014), considera a la guerra, el pillaje y el bandolerismo como un medio natural de adquisición y, como tal, parte de la economía.

25 En algunos casos se introducen comentarios racistas para omitir estas situaciones, como por ejemplo en Bentham, quien señala que sus reflexiones políticas y económicas no son aplicables para territorios poblados por razas no blancas (Rodriguéz Braun, 1989). Pero no se puede generalizar esta posición a la escuela clásica. De acuerdo a Schwartz (1968), la posición de Stuart Mill fue contraria a la esclavitud.

26 Ver el punto 4 del Capítulo II, Libro 2, en la traducción de 1943.

27 Para el citado autor, el problema es más marcado en los viejos países (Europa), que en los países 
En síntesis, la economía clásica no objetó el fin de hacerse personalmente rico dentro de una sociedad, pero dejó fuera del objeto de estudio de la economía ese fenómeno. Por otra parte, los medios para lograr este fin fueron en algunos casos dejados fuera de la disciplina (particularmente la violencia) y en otros casos cuestionados (los monopolios y en ocasiones la herencia).

A partir de la década de 1870, la economía clásica comienza a ser reemplazada por la economía neoclásica. Esta última se basa en ciertos principios unificadores, tales como el análisis de la oferta y la demanda, las situaciones de equilibrio, el análisis marginal (utilidad marginal, productividad marginal, etc.), y fundamentalmente el modelo de elección racional. En nuestra opinión, esta corriente de pensamiento no ha modificado el enfoque de la economía clásica sobre la acumulación de grandes riquezas personales, sino que lo ha profundizado.

Los análisis de equilibrio de mercado competitivo, ya sea en forma parcial según la tradición de Marshall, o general en la tradición de Walras, no son compatibles con el estudio de la acumulación en corto tiempo de grandes riquezas personales, que es generalmente un fenómeno transitorio o de desequilibrio ${ }^{28}$. La teoría de la distribución, basada en la teoría de la productividad marginal, permite, suponiendo condiciones de competencia, distribuir el producto sin que exista un resto o excedente, que podría constituir un medio para la rápida acumulación de riqueza personal. El monopolio ya no se considera de origen exclusivamente legal, sino que en algunos casos es "natural" y conveniente para la sociedad. Pero las ganancias monopólicas que podrían permitir acumular grandes riquezas personales son consideradas perjudiciales, y son calificadas como un abuso de posición dominante.

Algunas extensiones propias de la economía neoclásica tampoco serán compatibles con el estudio de la rápida acumulación de grandes riquezas personales. Por ejemplo, la teoría del mercado perfecto de capitales explica por qué no se pueden acumular rendimientos extraordinarios en forma sistemática en el mercado de capitales, y sólo puede explicar cómo se logran los mismos a partir del abuso de información interna por parte de algunos agentes; cuestión que éticamente es reprochable, y también lo es en la actualidad desde un punto de vista legal (Fama, 1970).

Finalmente, se reconoce la posibilidad de obtener rentas de escasez, como por ejemplo cuando se trata de recursos naturales no reproducibles por el hombre, o rentas de agotamiento cuanto se trata de recursos no renovables. Pero no se explica cómo estos activos no reproducibles pertenecen a algunas personas y no a otras.

En síntesis, dentro del pensamiento neoclásico, el fin de acumular riquezas personales rápidamente a partir de la actividad personal no es tratado explícitamente ni se observan los casos en que ocurre. Por otra parte, se continúan excluyendo la violencia ${ }^{30}$, como un

jóvenes (América).

28 Este punto quedará bien ilustrado al analizar la teoría de Schumpeter, que se expondrá en el apartado 7. Cabe señalar que la acumulación de grandes riquezas personales es compatible con el análisis de equilibrio en el caso del monopolio, pero no con otros análisis como la teoría de la competencia imperfecta, o de la competencia monopolística desarrollada por Chamberlin.

29 El término "natural" parece poco feliz, dado que el origen de este tipo de monopolios es generalmente tecnológico, y da como resultado que sea menos costoso que un solo establecimiento atienda toda la oferta a que sean varios.

30 A principios del siglo XX, aún se observa cierta ambigüedad frente al racismo. Por ejemplo en un precursor neoclásico como Irwin Fischer (1906), quien clasifica dentro de las formas de riqueza a los esclavos, reconociendo además que las transferencias pueden ser voluntarias o involuntarias. Puesto que estas últimas son producto de la fuerza o del fraude, Fischer señala que sólo estudiará las transfe- 
medio a considerar, y otros medios que permitirían lograr dicha acumulación son valorados negativamente, tales como las ganancias monopólicas, que se conceptúan como un abuso de posición dominante, o el empleo de información interna en el mercado de capitales.

\section{Schumpeter y la acumulación de riquezas personales}

Schumpeter es un autor importante para este trabajo, pues trató expresamente la acumulación de grandes riquezas personales y los medios para lograrlo. Si bien lo hizo siempre asumiendo que esta discusión correspondía a la Sociología y no a la Economía, estableció de hecho un puente entre ambas disciplinas, porque en gran medida los argumentos empleados para fundamentar sus afirmaciones sociológicas son de tipo económico. El límite entre ambas disciplinas es borroso en el caso de Schumpeter, y consideramos que puede pensarse como una región de solapamiento, más que una frontera nítida.

Una característica notable del pensamiento de este autor es su sensibilidad a los problemas que le tocó vivir. Esto permite observar con mayor facilidad los valores no epistémicos que incluyen sus teorías. La economía clásica, particularmente a partir de David Ricardo, se caracterizó por sus grandes abstracciones, mientras que la economía neoclásica le ha agregado una gran dosis de formalismo (Fama, 1970). Schumpeter privilegia en sus teorías el dar respuesta a diferentes críticas que padece en su tiempo el sistema económico liberal o el capitalismo. Para él es más importante proveer teorías que cumplan con este objetivo, antes que determinar si las mismas son compatibles o no con las grandes abstracciones del pensamiento clásico, o si son o no tratables con el aparato formal de la economía neoclásica.

\section{VI.1. La violencia como medio de acumulación de riqueza}

Una cuestión que Schumpeter (1965) trata en forma directa es la relación de la empresa capitalista con el Imperialismo, incluyendo en este marco el empleo de medios violentos, en particular la guerra, para hacer dinero. No se trata necesariamente de un uso directo de la violencia por parte de monopolios mercantiles, como ocurrió particularmente en los siglos XVI y XVII, pero sí del aprovechamiento económico indirecto de oportunidades que la guerra podía proveer. La respuesta de Schumpeter es que la guerra es un rasgo antiguo, un atavismo irracional. La guerra se hace por la guerra misma, y las empresas modernas no lo utilizarían, fundamentalmente porque sería un mal negocio.

A fin de fundamentar su opinión, Schumpeter cita una serie de casos históricos. Pero una vez abierta la discusión sobre un fenómeno económico, social o político, la misma ya no puede cerrarse por la apelación a la evidencia empírica, porque es un recurso insuficiente. En este caso, las limitaciones particulares de la evidencia histórica que aporta Schumpeter son muy importantes, dado que se remonta a imperios antiguos tales como Egipto, Asiria y Persia, para ilustrar el carácter atávico e irracional de los imperios, y se refiere a algunos casos puntuales del periodo mercantilista.

Sin embargo, la evidencia mencionada no es comprensiva de las distintas situaciones. En efecto, si bien en muchos casos es difícil encontrar una justificación económica para una guerra, hay ejemplos en que esto puede observarse con bastante claridad. Tal el caso de las denominadas Guerras del Opio, entre Gran Bretaña y sus aliados y China, que ocurrieron entre

rencias voluntarias, sin que quede claro cómo califica a la esclavitud. 
1839 y 1842 , y entre 1856 y 1860 . En estos conflictos, uno de los objetivos fue típicamente económico, y consistió en equilibrar la balanza comercial de Gran Bretaña respecto de China. Por otra parte, si se intentaba fundamentar que la moderna empresa de negocios no fomenta la guerra como un medio para obtener ganancias, Schumpeter debería haber analizado casos de imperialismos contemporáneos a sus escritos, donde estas empresas ya existiesen.

En otras palabras, es razonable suponer, como lo hace Schumpeter, que las guerras, al destruir parte de la economía de un país, son un mal negocio para muchas empresas, y puede suponerse entonces que muchas empresas no la fomentarían, sino todo lo contrario. Pero la magnitud que tienen las industrias dedicadas al suministro de insumos para enfrentamientos bélicos no puede desconocerse. Por otra parte, es público y notorio cómo ciertos tráficos ilegales se basan en la violencia como un medio para obtener ganancias.

En síntesis, en esta teoría de Schumpeter, tanto las decisiones sobre la teoría como sobre la evidencia empírica incluyen un sesgo valorativo. Sin necesidad de que aquello que se afirma sea falso, se seleccionan situaciones y evidencia que no reflejan la complejidad del fenómeno de manera equilibrada ${ }^{31}$.

\section{2. El monopolio y los trusts como forma de innovación}

Una segunda crítica social hacia las empresas, que también está presente en la época de Schumpeter, es la formación de "Trust". En la segunda mitad del siglo XIX se produce un proceso de concentración industrial muy rápido, que adopta como una de sus formas los "Trust". Estas organizaciones son equivalentes a los holdings actuales, o sea sociedades que detentan las acciones de un conjunto de otras empresas, a las cuales se las puede conducir a actuar en forma coordinada, dado que responden en definitiva a una misma conducción. Estos "Trust" fueron objeto de crítica social por sus efectos potenciales o reales sobre la competencia, y de esta preocupación emergen los primeros intentos de proteger la competencia mediante una legislación específica. La primera norma en USA es la Ley Sherman (1890), pero el caso más resonante en que se aplicó la misma ocurrió en 1911, cuando la Corte Suprema de USA tomó la decisión en el caso Standard Oil Co. v. United States, de obligar a dicha empresa a escindirse en 34 compañías diferentes.

Ese mismo año aparece la primera edición, en alemán, de la Teoría del Desenvolvimiento Económico de Schumpeter (1976). En esta obra se expone por primera vez el concepto de innovación como la puesta en práctica de nuevas combinaciones, el empresario innovador (como el agente que introduce estas nuevas combinaciones), y el desenvolvimiento económico como resultado de la innovación continua. Estas nuevas combinaciones incluyen: a) la introducción de un nuevo bien, o de una nueva calidad, b) la introducción de un nuevo método de producción, c) la apertura de un nuevo mercado, c) la conquista de una nueva fuente de aprovisionamiento, d) "la creación de una nueva organización de cualquier industria, como la de una posición de monopolio (por ejemplo por la formación de un trust), o bien la anulación de una posición de monopolio existente anteriormente" (Schumpeter, 1976, p. 77) (la cursiva es nuestra).

31 Conviene volver a recordar que no se está cuestionando la teoría de Schumpeter en particular, sino la posibilidad de que exista una ciencia económica valorativamente neutral. Si efectuásemos el mismo análisis a las teorías de origen marxista de Bauer y Hilferding, que asignaban la responsabilidad del imperialismo a las empresas capitalistas, también podriamos encontrar sesgos valorativos, aunque esta vez de sentido inverso, es decir, selecciones orientadas a remarcar sólo los aspectos socialmente disvaliosos de este tipo de empresas. 
Schumpeter considera que este proceso es vital para el desenvolvimiento de la economía y que justifica la existencia de ganancias monopólicas como incentivo a realizar las innovaciones, y eventualmente como forma de financiar las mismas ${ }^{32}$. $\mathrm{Al}$ respecto, señala que: Sin desenvolvimiento no hay ganancia, y sin ésta no hay desenvolvimiento. (Schumpeter, 1976, p. 159)

Schumpeter considera que los monopolios sólo serán transitorios, dado que el flujo mismo de nuevas innovaciones tenderá a erosionar sus bases y a crear en consecuencia otros monopolios, también transitorios. Su argumentación defiende la figura del monopolio como un medio socialmente valioso para estimular innovaciones y como una innovación en sí misma. El monopolio como medio ya no es reprochable, sino que es fruto de la labor admirable de los empresarios innovadores, y la obtención de ganancias extraordinarias es una condición necesaria para que este proceso continúe. Lo cual contrasta con la economía clásica y neoclásica, donde las ganancias extraordinarias derivadas del monopolio son reprochables.

En esta teoría, la innovación siempre es buena para la economía y para la sociedad, y esto justifica las ganancias extraordinarias que se obtienen de las mismas. El sesgo de esta opinión queda de manifiesto al considerar que pueden existir todo tipo de innovaciones, incluyendo algunas que pueden brindar grandes ganancias sin que sean necesariamente buenas para la economía y la sociedad en su conjunto. Por ejemplo, supongamos un nuevo método para eludir o evadir el pago de impuestos. Esto podría considerarse una innovación que puede brindar grandes beneficios, hasta que sea detectada por los fiscos y puesta bajo control.

Por otra parte, Schumpeter utiliza, en nuestra opinión, una técnica retórica para extender al "Trust" la valoración positiva que reciben otro tipo de innovaciones, tales como nuevos los productos o mercados. El sesgo valorativo se observa porque, al tratarse la figura del "Trust" en esta teoría, sólo se mencionan circunstancias que lo harían socialmente valioso, pero no aquellas que podrían originar una crítica al mismo, por obstaculizar el propio proceso de desenvolvimiento económico que Schumpeter defiende. ¿Acaso las combinaciones originadas en "Trust" no podrían operar limitando la introducción de nuevos productos, como una forma de mantener ganancias extraordinarias el mayor tiempo posible? ¿Por qué las ganancias monopólicas no podrían orientarse hacia usos socialmente discutibles, tales como la incidencia en los gobiernos para consolidar su posición monopólica? ¿Por qué suponer que las innovaciones sólo pueden ser estimuladas por las ganancias monopólicas, cuando existen casos en que la innovación es necesaria sólo para lograr permanecer en un mercado? Respecto de la temporalidad del monopolio, el argumento es poco claro, dado que lo que ocurra a lo largo de diez o quince años es importante, aunque sea temporal.

Nuevamente, el sesgo valorativo en la teoría no implica que las características mencionadas por Schumpeter respecto de los monopolios y trust sean siempre falsas, sino que podría ser falsa su generalización a todos los casos de monopolios constituidos por medio de trust.

\section{3. El origen de los nuevos ricos}

En otra de las oportunidades en que Schumpeter introduce su idea de empresario innovador el marco de referencia es otro. La economía mundial ha atravesado la gran

32 El mecanismo para financiar innovaciones, sobre el cual pone mayor énfasis Schumpeter, es la creación de poder de compra por los bancos, a partir de crédito bancario. 
depresión de la década del treinta, y se pone en cuestión la viabilidad del sistema capitalista, y la legitimidad de ciertas prácticas.

Antes de la Segunda Guerra Mundial, toma particular auge un tipo de periodismo que inicialmente se apodo "muckraker", y que fue un antecedente importante del actual periodismo de investigación. ${ }^{33}$ Se puede caracterizar al mismo como un periodismo de tipo reformador, que buscaba mejorar el sistema sacando a la luz los abusos que se producían. Estos abusos eran generalmente los medios reprochables de hacer dinero, ya sea cuestionando prácticas actuales, o bien las prácticas que habrían originado grandes fortunas personales en los Estados Unidos.

Esta visión crítica se encuentra presente también en la obra de un sociólogo de la importancia de Robert Merton. En su ensayo Estructura social y anomía, que data según este autor de 1938, y que fue publicado en inglés en 1949 como parte de Teoría y Estructura Sociales bajo el subtítulo "Innovación", se señala, entre otras cosas:

Una gran importancia cultural a la meta el éxito invita a este modo de adaptación mediante el uso de medios institucionalmente proscriptos, pero con frecuencia eficaces, de alcanzar por lo menos el simulacro del éxito: riqueza y poder. (Merton, 1964, p. 220)

Simultáneamente se produce (durante la crisis de la década de 1930) una discusión política importante en torno a viabilidad del socialismo y del capitalismo, y en este contexto la discusión con el pensamiento de Carlos Marx era de gran relevancia.

En Marx la economía y ña sociología no son disciplinas separadas. Existen en el capitalismo dos grandes clases sociales: los capitalistas y los proletariados. Los capitalistas incluirían a los ricos, y dentro de estos existirían algunos con fortunas heredadas y otros que han tenido la habilidad de acumular grandes riquezas por ellos mismos. La explicación de Marx sobre cómo algunas personas llegan a ser capitalistas es bastante limitada. En el Tomo I de El Capital (2004) es donde más elementos se proveen, especialmente en la "Teoría de la acumulación original". Esta teoría explica la rápida acumulación de capital a partir de un proceso histórico, ocurrido en la Europa del siglo XVII, de expropiación de tierras públicas o comunales por parte de una minoría. Existen asimismo referencias a la acumulación originada en el comercio exterior, derivado del primer colonialismo, y también al empleo original de la violencia.

Hay que entender que Marx escribió El Capital tomando como referencia a Inglaterra, y que los procesos que indica podían ser los más relevantes para el caso en cuestión. No obstante, la explicación brindada no abarca la formación de nuevas fortunas originadas en su totalidad. O sea, el fenómeno de emergencia de nuevos capitalistas o nuevas riquezas personales es permanente e incluso algunos de ellos proviene de las clases más desposeídas. Su origen ya no puede ser explicado por un proceso de expropiación de tierras, ni tampoco necesariamente con un comercio exterior realizado por potencias colonialistas. Por lo tanto, queda en este sentido un vacío, que será abordado por Schumpeter ${ }^{34}$.

$33 \mathrm{El}$ término "muckrake", que puede traducirse como "removedores de basura", fue introducido en 1906 por el entonces presidente de los Estados Unidos, Theodore Roosevelt, cuestionando el enfoque de estos escritos que sólo se concentraban en las cuestiones reprochables de los gobiernos. (Fedstein: 2006).

34 Posteriormente Kalecki (1956), dentro de la tradición marxista, reintroducirá el monopolio como factor explicativo de la distribución del ingreso a nivel macroeconómico. 
La obra Capitalismo, Socialismo y Democracia de Schumpeter (1946), publicada originalmente en 1942, trae nuevamente a colación la teoría del empresario innovador, y simultáneamente trata de responder a la crítica sobre la legitimidad de los medios de acumular riquezas personales, y al propio marco teórico de Karl Marx. El argumento es nuevamente que la innovación va de la mano del monopolio, y que a partir del mismo se generan las grandes fortunas personales, que elevan a gente en algunos casos de origen relativamente humilde a la condición de capitalistas ${ }^{35}$. Pero así como los monopolios tienden dinámicamente a ser sustituidos por otros monopolios, los que integran la clase capitalista luego de la generación que les permitió ascender a ese nivel comienzan paulatinamente a ver erosionada su posición económica y de clase. Ningún monopolio es permanente, y ninguna familia rica lo es indefinidamente.

Continuando con nuestra línea argumental, lo que señala Schumpeter no es falso como explicación de la emergencia de nuevos ricos, lo que no puede válidamente afirmarse es que todos los nuevos ricos son innovadores, al menos en el sentido en que Schumpeter emplea este término. Para explicar un fenómeno complejo, como es la emergencia de nuevos ricos, se recurre a una teoría que selecciona los casos que son socialmente aceptables y valiosos, y se omiten los casos en que la causa puede ser socialmente cuestionada. Existe entonces una decisión implícita sobre qué casos seleccionar, y qué casos omitir, donde aquellos que se mencionan son los que reflejan valores sociales positivos, mientras que los que se omiten podrían estar asociados a disvalores sociales.

\section{4. Consideraciones finales sobre la teoría del empresario y la formación de riquezas personales}

La teoría de Schumpeter, si bien no se convierte en parte de la corriente principal de la economía, sí es muy tenida en cuenta en la discusión política. El enfoque de este autor, que puede caracterizarse como de desequilibrio, fue difícil de incorporar a los modelos de la economía neoclásica, basados en condiciones de equilibrio. Su explicación de la formación de las grandes fortunas personales fue calificada por él mismo como una respuesta al pensamiento sociológico de Marx y no a su pensamiento económico; sin embargo, es indudable que establecía un nexo claro entre la dinámica económica y la formación de las clases sociales.

Schumpeter permite despejar además las dudas en torno a la posibilidad de una ciencia sobre la formación de grandes fortunas personales. En efecto, se podría pensar que, si se descubriese la forma de lograr este fin, serían tantos los que lo emplearían, que rápidamente desaparecerían las oportunidades para acumular riquezas. Pero Schumpeter demostró que era posible proponer una teoría explicativa, aunque parcial sobre este fenómeno, y que la misma era apta para realizar predicciones generales, que al igual que ocurre con la teoría de la evolución de Darwin, no puede indicar con exactitud cuándo y cómo se presentara el fenómeno estudiado ${ }^{36}$.

35 La idea de que el empresario innovador se eleva socialmente y que luego de un ciclo puede decaer nuevamente, está ya manifestada en Schumpeter (1976), pero recién se expone como critica a la teoría de Marx en Capitalismo, Socialismo y Democracia.

36 La tendencia a formular teorías que puedan explicar los éxitos pasados y hacer algunas predicciones generales sobre el futuro, se puede observar en la vasta literatura sobre las empresas (que no está incluida en la economía clásica ni neoclásica), especialmente en las teorías que tratan de explicar su rápido crecimiento. A título de ejemplo, podemos citar al estudio de 1946 de Peter Druker sobre General Motors, y el estudio de Alfred Chandler de 1962 sobre las empresas ferroviarias. Cabe señalar que, 
Se considera que no se ha estudiado aún en detalle el impacto que tuvo la Guerra Fría en la teoría económica. Es posible que la figura del empresario haya sido particularmente cuidada durante ese periodo. Esto podría explicar cómo, recién al año siguiente de la caída del Muro de Berlín, un economista muy prestigioso,William Baumol, publica en el año 1990 el trabajo titulado Entrepreneurship: Productive, Unproductive and Destructive. La característica de este trabajo es que llama la atención sobre la figura del empresario, ya no destacando exclusivamente sus aspectos positivos, sino con una visión más amplia, que permite la consideración de distintos casos, algunos socialmente valiosos y otros disvaliosos ${ }^{37}$.

Por otra parte, durante un largo periodo de tiempo, que incluye la Guerra Fría, no abundan los estudios académicos sobre la formación de las grandes riquezas personales. En este marco se destaca el trabajo de Wright Mill (1987), publicado originalmente en 1956. Recientemente, cabe mencionar también el trabajo de Handbook, publicado sobre los super ricos, y editado por Hay y Bearsbestok (2016). Ahora bien, en este último trabajo, al igual que en Adam Smith, el interés se centra en las formas de vida y patrones de consumo, antes que por las formas de acumulación de estas grandes riquezas.

\section{Conclusión}

En este trabajo hemos analizado las formas en que los juicios de valor no epistémicos afectaron y continúan afectando al contenido de la ciencia económica. Se han analizado dos formas en que esto ocurre. En primer lugar, hay juicios de valor no epistémicos sobre lo que es importante o prioritario estudiar, y lo que no lo es. En segundo lugar, están los juicios de valor que se introducen en la parcialidad de las teorías y/o de la evidencia empírica.

Respecto al primer mecanismo, un cambio en los valores que se consideran importantes para orientar la investigación puede afectar drásticamente el contenido de la ciencia económica o enfoque positivo. Para fundamentar esta posición, se ha tomado como ejemplo histórico al lugar cambiante que ocupó, en la teoría económica, la problemática de hacerse personalmente rico en un corto periodo de tiempo.

Se ha señalado cómo el lugar que ocupó esta problemática cambia drásticamente entre el mercantilismo y la economía clásica. La economía clásica no trata en forma exclícita el objetivo de acumular rápidamente grandes riquezas personales. Abstrae de su objeto de estudio el empleo de la violencia como un medio, porque es contraria a sus objetivos prioritarios, que fueron inicialmente la libertad económica como parte de un sistema de libertades más amplio. El monopolio no es visto desde la perspectiva de su contribución al objetivo de acumular riquezas personales, sino como un obstáculo a la libertad de comercio. Por otra parte, esta escuela de pensamiento no desarrolla ninguna teoría sobre la forma rápida de acumular riquezas personales. Este cambio en la ciencia no puede ser explicado por un método científico, porque son decisiones previas a que el mismo se lleve a cabo y, por otra parte, porque se trata de alternativas que no son lógicamente excluyentes entre sí. Tampoco puede explicarse apelando a valores epistémicos o cognitivos, tales como la verosimilitud, simplicidad, precisión, etc.

para algunas teorías económicas, como los postkeynesianos, el rápido crecimiento de una empresa está asociado a una alta tasa de ganancia.

37 Esta línea de trabajo ha continuado posteriormente. Véase, por ejemplo, el libro publicado por Baumol, Litan, y Schramm (2007), donde analiza un "Capitalismo bueno" y un "Capitalismo malo", a partir de cuatro formas: empresarial, de campeones, guiado por el estado y oligárquico. 
El abandono del estudio de las formas rápidas de acumulación de riquezas personales fue, a nuestro juicio, algo que ocurrió a raíz de valores no epistémicos. Cabe recordar que el propio Adam Smith, en su Teoría de los Sentimientos morales, desestimó, en base a consideraciones éticas, el objetivo de la acumulación de riquezas personales. Esta ausencia de consideración se transmitió desde la economía clásica a la economía neoclásica, la cual no alteró sustancialmente esta situación, aunque desarrolló el estudio del monopolio en relación al nuevo objetivo de la asignación óptima de recursos, y dentro de este marco incluye el caso del monopolio natural.

Por otra parte, los fines considerados valiosos transmiten esa valoración a los medios para conseguirlos. Siendo la acumulación de riquezas personales un fin valorado positivamente para el mercantilismo, el monopolio como un medio para lograrlo fue a su vez valorado positivamente. En el caso de la economía clásica, ocurrió lo opuesto. El fin de lograr rápidamente riquezas personales no fue explícitamente considerado, y el monopolio fue duramente cuestionado por sus efectos particularmente adversos sobre el libre comercio.

El segundo mecanismo considerado en este estudio es la introducción de juicios de valor implícitos en la parcialidad de las teorías y/o de la evidencia empírica. Este mecanismo se ha analizado en relación a las teorías sobre la actividad empresarial propuesta por Schumpeter y su relación con el caso que vertebra este estudio, que es la acumulación rápida de grandes riquezas personales.

Los juicios de valor que se introducen en la teoría surgen como respuesta a una problemática social existente al momento de formular las teorías, a la cual no podía dar respuesta la economía clásica ni neoclásica. En particular, las agudas controversias sobre la violencia como medio directo o indirecto de acumular riquezas en la época de guerras coloniales, la existencia de monopolios y trust, y el cuestionamiento de legitimidad del origen de algunas grandes riquezas personales. La obra de Joseph Schumpeter se presenta como una respuesta a estos interrogantes, siguendo una formulación original y ajena al pensamiento clásico y neoclásico.

Este autor analizó el problema de la utilización de medios violentos para hacer directa o indirectamente ganancias, y concluye que esto no es propio de la moderna empresa de negocios, basándose en una evidencia empírica parcial, escasa y, en nuestra opinión, valorativamente sesgada. A su vez, califica a la formación de monopolios como un medio aceptable y necesario para la dinámica del crecimiento económico, apoyado en casos en que podría ser favorable a este objetivo, y omitiendo casos en que podría ser contrario. Finalmente, explica la emergencia de grandes riquezas personales como fruto exclusivo de la actividad de innovación del empresario, pero omite otras formas de hacerse rico, que podrían ser socialmente cuestionables.

En todos los casos, los juicios de valor no epistémicos se reflejan en la parcialidad de la selección, donde las características mencionadas son socialmente aceptables, o incluso admirables, y se omiten aquellas que podrían ser socialmente reprochables. Lo que afirma Schumpeter no es falso, pero tampoco es una teoría que exponga en forma equilibrada las distintas situaciones posibles. Esto se pone de manifiesto al contrastar la visión de Schumpeter con algunos escritos de Baumol posteriores a la finalización de la Guerra Fría.

Las observaciones de campo que se realizan son influidas, o recortadas, por los juicios de valor no epistémicos que guían la investigación. Si cambiasen estos juicios de valor, cambiaría la dirección en que avanza la teorización e investigación, y cambiarían también los atributos de los fenómenos observados. 
Adicionalmente, es dable observar una correlación más amplia entre fines y medios. Tanto en el pensamiento mercantilista como en la obra de Schumpeter, al reconocerse como objetivo valioso la rápida acumulación de riquezas personales, se debe reconocer también como valioso algún medio que permita lograrlo. En ambos casos, un medio aceptado es el monopolio. En el pensamiento clásico y neoclásico, el objetivo de rápido enriquecimiento personal no ocupa un lugar destacado y, paralelamente, los medios que permitirían lograrlo son cuestionados, como por ejemplo las ganancias monopólicas consideradas un abuso de posición dominante, o las ganancias extraordinarias obtenibles en el mercado de valores a partir de información interna.

\section{Bibliografía}

—Aristóteles. (2014). La Política. Buenos Aires: Terramar Ediciones.

-Baumol, W., Litan, R., Scharamn, C. (2007). Good Capitalism, Bad Capitalism, an the Economics of Growth and Prosperity. New Haven \& London: Yale University Press.

-Borello, R. (2006). Epistemología de la economía: validación, significado y realidad en la teoría económica. Buenos Aires: Ediciones Cooperativas.

-Borello, R. (2008). Adam Smith o los fundamentos de la economía politica. Buenos Aires: Ediciones Cooperativas.

—Bunge, M. (1995). Economía y Filosofía. Madrid: Editorial Tecnos.

-Canan, E. (1922). Wealth: a brief explanation of the causes of economic welfare. Londres: P. S. King \& Son Ltd.

-Chandler, A. D. Jr. (1990). Scale and Scope. The Dynamics of Industrial Capitalism. Cambridge: Harvard University Press.

-Crespo, R. (1997). La economía como ciencia moral, nuevas perspectivas de la teoría económica. Buenos Aires: Ediciones de la Universidad Católica Argentina.

—Druke, P. (1946). Concept of the Corporation (A study of General Motors). John Day.

-Echevería, J. (1998). Filosofía de la ciencia. Madrid: Akal.

-Fama, E. F. (1970). Efficient Capital Markets: a Review of Theory and Empirical Work. The Journal of Finance, 25 (2).

-Fischer, I. (1906). The nature of capital and income. Londres: Mac Millan.

-Fox, J. (2009). The Myth of the Rational Market: A History of Risk, Reward and Delusion on Wall Street. USA: Harper Business.

—Friedman, M. (1953). The Methodology of Positive Economics. En Friedman Milton, Essays in Positive Economics Chicago. Chicago: The University of Chicago Press.

—Gómez, R. J. (1995). Neoliberalismo y Seudociencia. Buenos Aires: Lugar Editorial.

-Guerrero Pino, G. (2000). Elección de teorías, juicios de valor y racionalidad en Khun, ÉNDOXA: Series Filosóficas, (13), pp 15-32.

-Hay, I. y Beaberstok, J. (2016). Handbook on Whealth and the Super-Rich. Cheltenham UK: Edward Elgar Publishing.

—Harberger, A. C. (1971). "Three Basic Postulates for Applied Welfare Economics: An Interpretive Essay". Journal of Economic Literature, 9(3), pp. 785-797.

-Heckscher, E. (1943). La Época Mercantilista: Historia de la organización y las ideas 
económicas desde final de la Edad Media hasta la Sociedad Liberal. México D. F.: Fondo de Cultura Económica

-Hicks, J. (1939). "The Foundation of Welfare Economics". The Economic Journal Volumen, 196(29), pp. 696-712.

-Hutchison, T. (1960). The Significance and Basic Postulates of Economic Theory. New York: Augustus M.Kelley,

-Hutchison, T. (1971). Economía Positiva y Objetivos de Política Económica. Barcelona: Editorial Vicens Vives.

-Kalecki, M. (1956). Teoría de la dinámica económica. México D. F.: Fondo de Cultura Económica.

-Keynes, J. N. (1891). The Scope and method of political economy. Londres: Macmillan and Co.

—Kuhn, T. (1971). La estructura de las revoluciones cientificas. México D. F.: Fondo de Cultura Económica.

—Little, I. y Malcolm, D. (1950). A Critique of Welfare Economics. London: Oxford University Press.

-Makinw, G. (2002). Principios de Economía. Segunda Edición: McGraw-Hill.

-Marx, K. (2004). El Capital. Tomo I, Volumen 3. Siglo XXI: Editores.

-Mayer, T. (1993). Truth versus Precision in Economics. Aldershot UK: Edward Elgar.

-Marques, G. (2004). De la mano invisible a la economía como proceso administrado. Una reflexión filosófica y epistemológica. Buenos Aires: Ediciones Cooperativas.

-Merton, R. (1964). Teoría y Estructura Sociales. México D. F.: Fondo de Cultura Económica.

-McCloskey, D. N. (1985). The Rhetoric of Economics. Madison: University of Wisconsin Press.

—McCloskey, D.N. (1990). If You're So Smart: The Narrative of Economic Expertise. Chicago: University of Chicago Press.

-Mill, J. S. (1997). Ensayos sobre algunas cuestiones disputadas en economía política. Madrid: Alianza Editorial.

-Mill, J. S. (1943). Principios de Economía Politica. México D. F.: Fondo de Cultura Económica.

—Mills, W. (1987). La élite en el poder. México D. F.: Fondo de Cultura Económica.

-Mun, T. (1954). La Riqueza de Inglaterra por el Comercio Exterior. Discurso acerca del Comercio de Inglaterra con las Indias Orientales. México D. F.: Fondo de Cultura Económica.

-Myrdal, G. (1953). The Political Element in the Development of Economic Theory. Londres: Routledge and Kegan Paul.

-Nicholson, W. (2001). Microeconomía Intermedia y sus Aplicaciones. España: Thomson.

-Pardo Beltrán, E. (2000). "La pobreza en Smith y Ricardo". Revista de Economía Institucional, (2), pp. 111-130.

-Popper, K. R. (1973). La miseria del historicismo. Madrid: Alianza.

-Popper, K. R. (1991). La sociedad abierta y sus enemigos. Barcelona: Paidós 
-Rivera, S. (1994). Ludwig Wittgenstein entre paradojas y aporias. Buenos Aires: Almagesto.

—Rodríguez Braun, C. (1989). La cuestión colonial y la economía clásica. Madrid: Alianza.

—Robbins, L. (1944). Ensayo sobre la naturaleza y significación de la Ciencia Económica. México D. F.: Fondo de Cultura Económico.

-Samuelson, P. y Nordhaus, W. (2006). Economía. México D. F.: McGraw-Hill

-Schiffrin, A. (Comp) (2014). Global Muckraking: 100 years of investigative journalism from around the world. New York/London: The New Press.

-Schumpeter, J. (1976). Teoría del desenvolvimiento económico. México D.F.: Fondo de Cultura Económica.

-Schumpeter, J. (1965). Imperialismo. Clases Sociales. Madrid: Tecnos.

-Schumpeter, J. (1946). Capitalismo, Socialismo y Democracia. Buenos Aires: Editorial Claridad.

-Schumpeter, J. (1971). Historia del Análisis Económico. Barcelona: Ariel.

—Schwartz, P. (1968). La nueva economía política de John Stuart Mill. Madrid Editorial Tecnos.

—Smith, A. (1987). Investigación sobre la naturaleza y causas de la riqueza de las naciones, México D.F.: Fondo de Cultura Económica.

-Smith, A. (1982). The Theory of Moral Sentiments. Indianapolis: Liberty Fund.

-Wilbur, Ch. K. y Hobskergen, R. (1998). "Ethical Values and Economic Theory: A Survey”. En Wilbert, Ch. (Edit.). Economics, Ethics, and Public Policy. Nueva York: Oxford Rowman y Littlefield Publishers, Inc.

-Zanotti, G. J. (2001). "Una salida para el estancamiento epistemológico de la Escuela Austríaca”. Revista de Instituciones, Ideas y Mercado, pp. 5-14. 



\section{Perspectivas}





\title{
Cómo juntar el agua y el aceite: metodología científica y hermenéutica según Roxana Ynoub
}

\author{
Cristina Ambrosini \\ cristinaambrosini@gmail.com \\ Rec.02/09/17, Apr.24/10/17
}

Para la epistemología positivista y neopositivista, la simple asociación de los términos "hermenéutica" y "método científico" es un escándalo, cuanto menos, una contradicción, ya que no admiten que la hermenéutica cumpla con los requisitos de objetividad y contrastabilidad necesarios para validar las teorías científicas. En esta tradición logicista, la metodología de la investigación científica está marcada por la tendencia a privilegiar unas argumentaciones sobre otras, en la búsqueda de un único método que dirima la legitimidad de las teorías en el campo de las ciencias naturales y sociales mientras que, otra tradición, ligada a enfoques historicistas, propone la autonomía de las ciencias sociales o la postulación de otra forma del monismo metodológico, quizás tan reduccionista como el positivista, pero ahora sobre la base de la admisión de los enfoques hermenéuticos para todas las ciencias. Así es que aparecen las polarizaciones tradicionales entre ciencias duras y blandas, entre enfoques cuantitativos y cualitativos, entre explicacionistas y comprensivistas y otros antagonismos que pueblan los manuales dedicados a estos temas.

La epistemóloga argentina Roxana Ynoub presenta en dos de sus obras recientes (2012, 2014), la viabilidad de un tipo de hipótesis llamada "hipótesis hermenéutica" y en este punto recurre al concepto peirceano de "abducción”. El enfoque propuesto por Ynoub, basado en un enfoque dialéctico, es el resultado de la experiencia sostenida en el dictado de cursos de grado y de posgrado en diversas carreras de formaciones científicas y profesionales que representan verdaderos desafíos al planeamiento de la investigación. Su desempeńo abarca una variedad de disciplinas como las que atraviesa su participación en el Doctorado en Artes de la Universidad Nacional de La Plata, en el Doctorado en Ciencias Cognitivas en la Universidad Nacional del Nordeste, en la Maestría en Metodología de la Investigación Científica de la Universidad Nacional de Lanús y en la Maestría en Epidemiología, Gestión y Políticas en Salud de la misma Universidad, entre otras. Resulta oportuno destacar que esta ductilidad para encaminar investigaciones en territorios que hacen estallar la tradicional división disciplinar está propiciada por su formación y carrera docente en la Facultad de Psicología de la Universidad de Buenos Aires de donde es egresada como Licenciada y como Doctora. Esta sólida formación e intensa trayectoria docente avalan el despliegue de una "caja de herramientas" conceptuales, novedosas y creativas, para acceder a un terreno minado por dicotomías y polaridades que merecen ser superadas. Las ciencias sociales y especialmente la Psicología han sido una especie de "territorio comanche", rebelde e insumiso frente al monismo metodológico 
ya que han padecido los criterios de demarcación que las han relegado, en tono piadoso, a la categoría de "ciencias blandas", como dijimos, o directamente han sido expulsadas como "pseudociencias" y han tenido que elaborar sus propios cánones metodológicos. En sus escritos Ynoub destaca también su punto de partida y fuente de inspiración en la obra de quien fuera su maestro y compañero de vida, el Dr Juan Samaja. Podemos agregar que en sus propuestas metodológicas encontramos un aporte original y novedoso que va más allá de los marcos teóricos iniciales para avanzar, con paso firme y seguro, en la revisión de los fundamentos lógico-metodológicos para la toma de decisiones prácticas de la producción científica.

El concepto de "hermenéutica" lo toma de Paul Ricouer, a partir de aceptar que lo hermenéutico se relaciona con la "interpretación simbólica" y define al símbolo como un signo multívoco o más precisamente, equívoco. (Ynoub, 2012, p. 235) Lo que sugiere Ynoub es que en una investigación hermenéutica, una vez formuladas las hipótesis interpretativas que surgen por analogía con un sistema teórico significante, la contrastabilidad de estas hipótesis se haría mediante abducción, y la misma se resuelve en términos de admisibilidad. Para ilustrar esta idea propone la interpretación del ritual de la torta de cumpleańos tal como se lo practica en nuestro medio cultural. Para ello toma como ejemplo la teoría del antropólogo francés, René Girard (1923), según el cual "el origen de la cultura se funda en una experiencia violenta”. Para su fundamentación y validación recurre a un sinnúmero de evidencias históricas, antropológicas, literarias y psicológicas, provenientes de variadas fuentes. Las preguntas que orientan este análisis podrían ser formuladas en los siguientes términos: ¿Qué sentido se vehiculiza cuando soplamos la torta de cumpleaños? La hipótesis afirma: "El ritual de la torta de cumpleaños constituye un ritual expiatorio o un sacrificio expiatorio". Un ritual expiatorio, en este marco teórico, tendría las siguientes características:

1) Por una parte tenemos a la "víctima": debe ser un ser viviente, en tanto el ritual consiste en su sacrificio. En los orígenes de la cultura estas víctimas solían ser sujetos humanos, pero luego fueron desplazándose hacia animales u objetos que representaban a estos seres vivientes.

2) La víctima por lo general es preparada, acicalada, adornada para el ritual.

3) El ritual consiste en una ceremonia en la que se realiza el sacrificio. Este debe realizarse en presencia del grupo, se trata de una ceremonia colectiva.

4) Luego del sacrificio el grupo introyecta efectiva o simbólicamente a la víctima.

5) La realización del ritual tiene efectos consagratorios para el grupo y/o algunos de sus miembros: instituye un nuevo estado de cosas y los que participan en él se inscriben (o reafirman su inscripción) como miembros de ese grupo.

Tomando en cuenta estas significaciones, luego se trata de identificar las correspondencias entre este modelo y el material a interpretar; en este caso, el ritual de soplar las velitas de la torta de cumpleaños, según lo presenta Ynoub:

1) Vamos a postular que tenemos el objeto o el "cuerpo" de la víctima, en la torta misma. Se podría objetar que la torta no tiene vitalidad: no se puede cumplir en ella el acto sacrificial. Sin embargo, aparece un elemento que cumple la función simbólica de lo vital, ya que se presta al acto de su anulación. Este elemento es el del "fuego de las velas". 
Cristina Ambrosini / Cómo juntar el agua y el aceite: metodología [...]/59

2) La equivalencia también aparece en el acicalamiento: la torta se adorna, se decora y esto forma parte de los preparativos del ritual.

3) De acuerdo con esta hipótesis, el equivalente al acto sacrificial, sería el acto de "apagar las velas". Y éste se cumple también en presencia del grupo.

4) Luego, la torta es "introyectada" por el grupo: la torta se comparte y se come grupalmente.

5) Por último, se puede reconocer también la función consagratoria del acto ritual: las velas que se apagan representan la vida pasada, la vida ya vivida, pero al mismo tiempo y por el mismo acto se abre la nueva vida. Los ańos cumplidos se cumplen -en el marco de este ritual- cuando se apagan las velas. Tiene así una función instituyente y consagratoria.

Si se acepta la equivalencia trazada, lo que hemos hecho es identificar cada uno de los componentes que constituyen el "acto sacrificial" y proponer su "equivalencia" con el "ritual de la torta de cumpleaños": éstos se ordenan según la función que cumplen en lo que podríamos llamar el sistema simbólico (ya que, como dijimos, los símbolos reconocen complejidad interna). La equivalencia funcional supone entonces que una misma función pueden cumplirla elementos materialmente muy disímiles: su valor es sólo "significante", y la significación surge por el lugar que ocupan en el sistema como un todo. Así, por ejemplo, postular la equivalencia entre «la vida" y el «fuego de las velas» queda habilitado por el contexto en que esa equivalencia queda trazada" (Ynoub, 2012, pp. 247-248). Este proceder se corresponde con el tratamiento analógico abductivo al que nos referimos previamente: las velas o las llamas en sí mismas y por sí mismas no suponen necesariamente expresión del elemento vital. Sin embargo, en la perspectiva del contexto en que se interpretan adquieren esta potencial significación. Es por referencia al contexto que el elemento significante (considerado como un rasgo o indicio) adquiere el estatuto de un significado concreto (como caso). Del mismo modo podrían interpretarse como partes del "ritual sacrificial" el tirón de orejas al que cumple años o el ritual de la piñata, a la que se la "castiga" hasta romperla y luego los niños comen lo que contenía. En algunas culturas, señala Ynoub, al nacer un niño se le adjudica un árbol y en cada cumpleaños se "castiga" al árbol en un sentido equivalente al tirón de orejas.

La pregunta ahora es: ¿cuál es la violencia que se sublima a través de estos rituales? -si aceptamos, como lo sugiere Girard, que el rito expiatorio busca poner cauce a una violencia estructural. Para responder a esta pregunta se recurre a otra teoría según la cual el nacimiento de un nuevo miembro en la comunidad, entraña una amenaza, provoca un miedo atávico o ancestral que debe ser conjurado con un rito de purificación a través de un bautismo. El nuevo miembro debe ser inscripto según un ritual. De modo que cada aniversario de este nacimiento nuevamente ritualiza esta violencia que necesita ser "simbolizada" socialmente. El ejemplo está orientado a mostrar que, más allá de la aceptabilidad de esta conjetura o hipótesis, lo que se advierte es que ninguna interpretación es posible si no se fundamenta en un modelo teórico que la organiza y le da contenido. En palabras de Ynoub (2012) la fuerza ideatoria de estas hipótesis brota de los nexos que saca a luz, de la originalidad que aporta, de los problemas que resuelve o de los problemas que abre. Sin teoría, sin ideas, sin imaginación... no hay ciencia ni interpretación posible.

A diferencia de los enfoques tradicionales, para Roxana Ynoub, el proceso de investigación nos convoca a pensar una articulación entre distintas formas de inferencias, y para ello propone la siguiente secuencia: 
1) La analogía hace posible el descubrimiento y la ideación de nuevas reglas.

2) La abducción hace funcionar la regla (concebida como la hipótesis de la investigación) a partir de la cual se hace la conjetura sobre el caso.

3) La deducción hace la predicción sobre la que se espera encontrar empíricamente (si se aceptan el caso y la regla) al modo hipotético-deductivo.

4) La inducción permite confirmar o rechazar la presunción realizada (Ynoub, 2014, p. 90).

Así es que en este planteo, la analogía y la abducción remiten al contexto de descubrimiento mientras que la deducción y la inducción se relacionan con el contexto de justificación. Esto indica que cuando no se confirma una hipótesis hay que "volver hacia atrás", hacia el proceso que condujo a formular dicha hipótesis, cotejar la identificación del caso o reformular la regla (teoría), (Ynoub, 2014, p. 91).

El enfoque de Ynoub tiene varios méritos que es necesario destacar ya que representa una toma de distancia con las versiones asépticas, despersonalizadas y bienpensantes de la ciencia como una actividad objetiva y neutral para mostrarla como un quehacer que se compromete siempre con aspectos éticos e ideológicos al partir de la comprensión de la Metodología como una forma de saber práctico, como disciplina metacognitiva y reconstructiva, tomando distancia de la tradición hegemónica que impone cánones y normas de carácter universal y ahistórico. Por el contrario, aquí, en un rasgo kantiano, se concibe :

[...] la metodología de la investigación científica como una disciplina encargada de examinar las condiciones de posibilidad de la práctica científica en sus múltiples dimensiones. En una dirección que podría definirse como metodología crítica. (Ynoub, 2014, p. 7)

Pero, a diferencia de las apropiaciones cientificistas de Kant, aquí se señalan múltiples dimensiones que no están puestas unas junto a otras sino que se implican e integran en una práctica científica compleja, mutifacética y plurideterminada. Distingue en este análisis las condiciones histórico-sociales a las que atiende la sociología de la ciencia; las condiciones institucionales de las que se ocupa la antropología de la ciencia; las condiciones lógico-inferenciales que tematiza la lógica de la investigación científica; las condiciones cognitivo-epistemológicas que atiende la filosofía de la ciencia y las condiciones operatorio procedimentales de las que se ocupa la metodología de la investigación científica en sentido restringido, donde se advierta la importancia del uso de inferencias analógicas y abductivas como parte integrantes del proceso de investigación junto a las inferencias inductivas y deductivas. La revalorización del aporte de Charles Sanders Peirce parte de los análisis de Samaja, pero no para venerarlos como productos ya logrados, sino para recrearlos y orientarlos hacia lo que la tradición hegemónica considera un oxímoron: una comprensión hermenéutica de la Metodología. Vemos aquí que, con la audacia que acompaña a la solidez teórica, Ynoub enfrenta al monismo metodológico y a su sucedáneo, el monismo axiológico que deriva de la aceptación acrítica de que la producción científica tiene como único valor la búsqueda de una verdad desinteresada e imparcial. En contra de las pretensiones de los enfoques tradicionales, aquí se considera que la Metodología reconstruye y tematiza lo que la investigación y la ciencia hacen sin esperar la consagración de los cánones y las reglas impuestos desde los enfoques prescritivistas. Quizás sea este rasgo lo que distingue a su propuesta de un recetario de cocina 
y de otras producciones de tal índole. Finalmente, siguiendo la analogía con las recetas de cocina, podemos ver que el agua y el aceite sí se pueden mezclar y a la operación que lo permite se lo llama "emulsionar". Se puede emulsionar el aceite con el vinagre, por ejemplo, junto a otros condimentos y lo que resulta es una vinagreta que sirve luego para condimentar distintos alimentos. Siguiendo con la comparación, entonces, podemos decir que la propuesta de investigación hermenéutica puede verse como una potente emulsión de elementos y ser la base para un sustancioso resultado científico.

\section{Bibliografía}

-Ynoub, R. C.( 2012). "Metodología y hermenéutica”. En Díaz, E. (Ed.). Investigación cientifica y biopoder. Epistemología, metodología y biopolítica, Buenos Aires, UNLaBiblos, pp. 233-55.

-Ynoub, R. C. (2014). Cuestión de Método. Aportes para una metodología crítica, Tomo 1. México: CENGAGE Learning. 



\title{
Modos descentrados de autoría en la era de la web participativa y social: el impacto de los nuevos medios en la producción y circulación de conocimiento académico
}

\author{
Mariana Ferrarelli \\ mariana.ferrarelli@gmail.com \\ Rec.19/10/17, Apr.02/11/17
}

\section{Presentación}

La forma de producir conocimiento desde la universidad es uno de los temas que ha ocupado la agenda de especialistas en diversos campos de investigación en los últimos ańos. En el ámbito de las ciencias sociales y de la comunicación, los estudios abordan cuestiones relacionadas con la evolución del ecosistema mediático y el impacto de lo digital sobre un diverso arco de prácticas sociales tales como la producción y gestión no sólo del saber científico, sino también de la información cotidiana que circula entre los actores sociales, la educación, la lectura de libros y otros medios impresos, etc. (Piscitelli, 2011 y 2010; Carlón, 2016; Leal Fonseca, 2010; Reig Hernández, 2010).

El objetivo de la presente propuesta consiste en identificar, sistematizar, analizar y formular categorías teóricas que permitan hacer inteligibles algunos procesos de naturaleza social, tecnológica y comunicacional que afectan el concepto de "autoría académica" tal como lo conocemos hasta ahora, especialmente asociado a la cultura letrada, esto es, la cultura centrada en la autoridad del libro impreso y el modelo industrial tanto en educación como en el ámbito político-económico. Para ello comenzaremos el recorrido teórico estudiando el valor analítico de la teoría sobre "El paréntesis de Gutenberg" (Sauerberg, 2009) y la convergencia digital. A continuación indicaremos los atributos de la cultura digital que señalan un alejamiento de los modos establecidos de autoría y creación y distribución de conocimiento para analizar finalmente tres casos de producción de saber que tienden a alejarse del paradigma tradicional. El objetivo reside en identificar contrastes, distancias y continuidades entre lo que denominamos los modos tradicionales y contemporáneos de producción y distribución de saber, analizando luego tres casos que ilustren una posible tipología sobre cómo se produce y gestiona el conocimiento académico en tiempos de convergencia digital y web participativa.

\section{Supuestos y propósitos de nuestro trabajo}

Ciertos movimientos registrados en el campo de los nuevos medios (Manovich, 2006), así como también en los modos de circular los mensajes en el ámbito de la comunicación, constituyen un eje sobre el cual es preciso concentrar el análisis para comprender su incidencia en el ámbito de creación autoral académica. El proyecto abarca tres objetivos: 
-Identificar y sistematizar prácticas de producción y circulación autoral académica alternativas al modelo impreso clásico y centralizado.

-Analizar las diferencias y similitudes entre los paradigmas clásico y contemporáneo a la luz de diversos desarrollos teóricos al respecto.

-Establecer categorías teóricas que permitan aprehender las nuevas transformaciones en el campo de la autoría académica.

- A continuación describimos los postulados que conforman las hipótesis de la investigación:

- La naturaleza de los nuevos medios y las prácticas contemporáneas de producción y circulación textual generan ámbitos alternativos de autoría académica que desbordan las estructuras y canales clásicos.

- Si bien aún se verifican estructuras rígidas que enmarcan y circunscriben la creación académica y buscan continuidades con el modelo tradicional, es posible identificar nuevos canales y modos de autoría que desafían los formatos clásicos.

\section{Tres escenarios, una teoría}

Entre los estudios que argumentan que la popularización del libro impreso en el siglo XV modificó la matriz cultural de Europa occidental, se desataca la investigación histórico-cultural de Walter Ong (2006), quien sostiene dos premisas: por un lado, que la escritura en tanto tecnología formatea la mente humana, y por otro, que la cultura digital eventualmente supone una vuelta a la oralidad en varios sentidos, lo cual cuestionaría, también a nuestro entender, el orden académico tradicional. Como señala Rodríguez Ruiz, la cultura digital afecta las prácticas de lectura y escritura de manera indiscutida: "Con la cibercultura el lugar de la obra se dispersa. Los roles se reconfiguran y ya no se puede hablar de un escritor y de un lector como entidades separadas, sino de un escrilector, alguien que despliega una inteligencia colectiva y produce sus propios textos en forma casi simultánea con su recepción" (en Reyes, 2005). El concepto de autoría, tal como lo conocemos tradicionalmente, se ve afectado por prácticas que descentran la autoridad del mundo letrado y erosionan sus bases canónicas.

Enunciada por el profesor Ole Sauerberg (2009) de la Universidad de Dinamarca del Sur, la teoría del 'Paréntesis de Gutenberg' postula que los cinco siglos de cultura letrada, caracterizados por el predominio de la escritura individual, canónica y fuertemente jerárquica, no serían más que una pausa momentánea, una interrupción temporaria del orden multifacético y cambiante de la oralidad que suponía recreación e inestabilidad para luego, en el momento actual, reafirmarse en la reapropiación y recontextualización de contenidos mediante la autoría colectiva que facilitan los medios digitales. Según este modelo, existiría un contraste entre los modos de producción textual tradicionales del mundo impreso y los momentos pre y post paréntesis, lo cual define tres escenarios diferentes que sirven como punto de partida para nuestro trabajo de investigación.

La cultura encerrada en el paréntesis de lo impreso (del siglo XV al XX) concibe el texto como entidad estable, cerrada sobre sí misma, y apostada sobre una jerarquía clara e incuestionable, aquella que diferencia al autor del lector. De estos dos roles, uno tiene la ventaja de la creación textual por sobre el otro, uno toma todas las decisiones creativas y se constituye en sujeto productor individual por excelencia, dueño de la verdad del texto. Más allá de las teorías 
Mariana Ferrarelli / Modos de autoría en la era de la web participativa [...] /65 que valoran la recepción, el lector queda en cambio relegado a un lugar de receptividad donde no posee medios para cuestionar la autoridad del libro. En el marco letrado, no cualquiera puede erigirse como autor; ese es un privilegio para unos pocos. El individuo 'gutenberiano' se apoya en la dualidad cartesiana para reafirmarse como sujeto.

En contraste, siguiendo la teoría del paréntesis, los modos de creación textual durante la oralidad 'pre-gutenberg' (hasta el siglo XV) favorecen la autoría colectiva por cuanto el relato es interrumpido y complementado por la audiencia expectante y dispuesta a participar. Lo más importante es que cada miembro de ese precario auditorio oficiará de narrador nuevamente en posteriores reuniones y rituales, en las cuales reproducirá y readaptará la versión anterior del relato en cuestión. Este relator recrea la historia o la información en cada nueva recitación y a su vez, como en aquel primer caso, recibe ajustes y agregados por parte de una nueva audiencia.

El tercer escenario es el que corresponde a la sociedad red (Castells, 1996) que fluidifica los intercambios sociales y favorece la circulación masiva de información. Los contrastes entre esta etapa y la anterior, parentética, son resonantes. Tradicionalmente, un autor escribía un texto que en general se plasmaba en formato de libro impreso y que a su vez era leído por un lector en silencio y desde un rol de pasividad y receptividad. Los roles estaban bien claros y jerarquizados: uno tenía en sus manos la voz del texto, las decisiones sobre su formato y creación; otro, muchos otros, sólo disponían de su lectura como forma de participación en el contrato autor-lector; no existía la posibilidad de reusar ese conocimiento en un nuevo formato textual, ni ampliarlo o reducirlo según sus necesidades. Por sus modalidades de comunicación, acceso a la información y construcción de conocimiento pre-impresas, las dinámicas de la convergencia digital (Doueihi, 2010) cuestionan el estilo individual de creación textual y disparan las posibilidades de colaboración e interacción hasta los límites más cotidianos.

El libro/texto tenía como tal un principio y un final bien claro otorgado por su propietario, el autor, y el formato estático de lo impreso que perdura en el tiempo sin modificación alguna de su contenido. Este mandato de "uno-a-muchos", impuesto por el libro en el que uno escribe y muchos leen/reciben, se impregnaría luego en los medios masivos de comunicación, que basan su funcionamiento en el mismo estilo "broadcast" de distribución del saber. En cambio, en la actualidad los medios digitales habilitan nuevos modos de participación en la creación textual, donde varios producen y varios reciben (Piscitelli, 2011; Tortosa, 2008) o donde es posible la producción colectiva de conocimiento (Landow, 2006) y la reutilización consentida de material preexistente para otros fines.

Mediante estudios, comparaciones y contrastes entre el exterior y el interior del paréntesis, esta pausa en la oralidad y sus modos expresivos y culturales, Suerberg se propone demostrar las notables similitudes entre oralidad y cultura digital que transforman el canon letrado en una mera interrupción pasajera del orden multivocal, creativo y móvil propio del pre y del post paréntesis. En palabras de Piscitelli, la teoría de Sauerberg supone

[...] la emergencia de una conciencia post-letrada para la cual el predominio del texto impreso en la producción cultural -no menos que la forma del libro- no ha sido más que una fase histórica que estaría llegando a su fin bajo el impacto de la tecnología digital e Internet. (Piscitelli, 2011, p. 26)

Si bien el modelo puede resultar reduccionista desde algunos enfoques (dado que limita a unas pocas características los atributos de un amplio compendio cultural), el 
Paréntesis de Gutenberg es interesante como dispositivo para establecer similitudes y diferencias, y para profundizar en la magnitud de las transformaciones que el paradigma digital supone para las culturas y sus formas de creación y transmisión.

Pensar en modos descentrados de autoría supone identificar procesos corridos del eje tradicional letrado, focalizado en el libro impreso y en sus figuras de autoridad como la escuela, la religión y el Estado-nación. Tal como señala Martín-Barbero (2003), el fenómeno de descentramiento implica "que el saber se sale de los libros y de la escuela, entendiendo por escuela todo el sistema educativo desde la primaria hasta la universidad". Este desarrollo, que hace desaparecer el núcleo organizador de jerarquías y diferencias, es paralelo a otras transformaciones relacionadas con el borramiento de los bordes que separan las disciplinas que conforman el conocimiento científico al interior de la ciencia, así como entre ese conocimiento y el saber común, menos especializado: "La diseminación nombra ese movimiento de difuminación tanto de las fronteras entre las disciplinas del saber académico como entre ese saber y los otros, que no proceden de la academia o no se imparten en ella de manera exclusiva", (Martín-Barbero 2003).

Los nuevos medios que permiten interacciones a través de la web, promueven mayores grados de participación e intercambios sociales y culturales que otorgan sentido a prácticas anteriormente exclusivas de una élite de fuentes de poder y saber autorizadas. Las tecnologías y dispositivos digitales presentan características que los distinguen de los medios tradicionales, a saber:

a) No intermediación: los usuarios publican producciones en las redes (Twitter, blogs, YouTube) directamente y sin editores, gatekeepers o agentes organizadores del contenido. Este atributo acelera los tiempos de producción, publicación, circulación y posterior consumo de la información.

b) Contenido expandido: los usuarios no deben esperar hasta un horario prefijado para consumir u obtener la información que desean; no son ellos los que van hacia el contenido, es el contenido el que va hacia los usuarios y está disponible para ser visto, leído o escuchado en todo momento (Jenkins, Green \& Ford, 2013).

c) Manipulación: al encontrarse en formato digital, los usuarios pueden apropiarse del contenido creado por otros y modificarlo, agregarle información, ampliarlo o reducirlo para sus fines personales. La interacción con la información es mayor y aumentan las posibilidades de su re-circulación o alteración de su forma original (pasar de texto a video, imagen a diagrama, sonido a texto o imagen, etc.). En tiempos de web social, la información circula y se comparte abiertamente y lo que surge en un lenguaje puede ser traducido sencillamente a otro. Una hora y media de conferencia puede ser transmitida en vivo por Internet y circular con posterioridad en forma de link, desgrabación o colección de imágenes por infinidad de ámbitos académicos y extra-académicos. Y dicha circulación no hace al conocimiento menos riguroso por viajar en video o texto desgrabado. La divulgación del saber científico ocurre en múltiples direcciones y formatos.

d) Arquitectura en red: se trata de una característica con profundas implicancias, no sólo a nivel técnico sino también político. Desde el punto de vista instrumental, los nuevos medios funcionan como una red de intercambios donde no hay una instancia central que regule las jerarquías, sino que las interacciones se producen de muchos a muchos. En términos políticos, los nuevos medios proponen barrer con las jerarquías tradicionales que ubicaban a los sujetos en diversos escalones de protagonismo y poder, tales como autor/lector, emisor/receptor, docente/alumno, experto/lego, activo/ 
Mariana Ferrarelli / Modos de autoría en la era de la web participativa [...] /67 pasivo. En la actualidad, el lector también es autor de sus contenidos en la web, el receptor se convierte en emisor de sus propios mensajes, y los intercambios son de idea y vuelta, más participativos, e involucran a todos los actores en un rol más activo y protagónico.

\section{Acceso abierto y uberificación del trabajo académico}

Si bien se acepta el avance establecido e irrevocable de la convergencia digital en todos los ámbitos de la vida cotidiana, Neil Selwyn (2016) no es muy optimista respecto de cómo las nuevas tecnologías están afectando el trabajo académico. El concepto que sintetiza su posición es el de Uberificación, una influencia que daña y diluye al trabajo académico, que queda reducido a mero proveedor de contenidos:

$[\ldots]$ the bottom line in academic publishing [...] no longer seems to be crafting a scholarly argument and adding knowledge. Instead, the end game of publishing, in the digital age is to engage and impact, to be open, to grow your online reputation and "brand". (Selwyn, 2016) ${ }^{1}$

Desde su perspectiva, el trabajo académico queda sujeto a prácticas no rentadas que comodifican la industria de publicación online y cuyos frutos retornan sólo en términos de mejor reputación o popularidad, visibilidad y marca personal, pero no representan grandes cambios desde lo económico.

La filosofía del acceso abierto emerge como resultado de la circulación que permiten los formatos digitales presentes en Internet. Si bien el trabajo de escritura, selección y edición de una publicación académica es el mismo, la posibilidad de hacerlo digitalmente y no en papel acelera los tiempos y multiplica las posibilidades de llegada a lectores de diversas áreas, tanto disciplinares como geográficas. Aunque parezca una obviedad, lo mismo ocurre con el proceso de la revisión por pares, que desde hace unas décadas se realiza por e-mail y prescinde del correo tradicional que demoraba el trabajo notablemente. Sin embargo, la cuestión del acceso abierto va mucho más allá de los aspectos funcionales que favorecen las nuevas tecnología, pues también plantea preguntas sobre el modo de pensar las publicaciones académicas y el conocimiento que ellas se encargan de difundir.

De acuerdo con Peter Suber (2004), los materiales de acceso abierto poseen cuatro atributos básicos: están disponibles online, se hallan publicados en formato digital, son gratuitos y no tienen restricciones de copyright. Dado que las publicaciones académicas no le pagan a los autores, el consentimiento de estos últimos para que sus artículos estén disponibles bajo la modalidad de acceso abierto no implica renunciar a algún tipo de ganancia económica. Este panorama contrasta notablemente con el caso de los contenidos de entretenimiento como la música y las películas, que basan su lucro económico en la facturación sobre la circulación de sus productos.

Aunque se realice en formato digital, la publicación de una revista académica no es gratuita en sí misma (Suber 2003 \& 2012, RCUK 2017); por el contrario, implica costos laborales sobre todo en la escritura, en el diseño final de cada artículo que se publica y el mantenimiento de los servidores y repositorios online. Pensar en clave de acceso abierto no supone reducir dichos costos al mínimo nivel, sino preguntarse por otros modos de hallar recursos económicos

1 "[...] el núcleo de la publicación académica [...] ya no parece estar asociado a la elaboración de un argumento académico o a la creación de conocimiento. Por el contrario, el objetivo de la publicación, en la era digital, es lograr visibilidad para tener impacto, ser abierto, hacer crecer la propia reputación en línea y la "marca" personal." (Selwyn, 2016) 
más allá de las restricciones de precio o de acceso para los lectores. En tal sentido, hay una infinidad de iniciativas (Budapest, Bethesda, Berlín) que promueven el acceso abierto a las publicaciones académicas, entre las que se destacan PLoS, DOAJ, etc.

\section{Autoría y escritura académica}

El vocablo academia designa las instituciones relacionadas con los niveles más elevados de educación. Por su etimología (De Echegaray, 1887), proviene del griego akademia, que designaba el lugar ubicado en Atenas donde Platón fundó la escuela de educación superior en el año 387 A.C. y donde se reunía a estudiar con sus discípulos.

¿Qué es la autoría? ¿Qué características reviste la "autoría académica”? Más allá de los análisis que designan el "autor" como una función que permite establecer un criterio de homogeneidad para un conjunto diverso de textos (Foucault, 1969), una rápida mirada sobre la historia de las primeras universidades permite concluir que, a partir del siglo XIII, cuando comienza la creación de casas de altos estudios, empieza a emerger el denominado conocimiento académico, es decir, el saber gestado en entidades especializadas en una determinada disciplina que detentan la autoridad de conocimiento experto y profundo sobre los temas asociados a ella. El conocimiento académico es por lo tanto aquel saber que es concebido en las cátedras universitarias fruto de la investigación y de la estructuración formal de la educación.

A los fines del presente trabajo, distinguiremos entre escritura y autoría académica. La escritura académica consiste en las producciones realizadas en el ámbito universitario y científico. Incluye los trabajos producidos por los alumnos universitarios (exámenes, trabajos prácticos y monografías), así como aquellos documentos elaborados en la academia para la difusión del conocimiento científico. En cambio, mediante el término "autoría académica" nos referiremos a los marcos donde ciertos actores considerados expertos en un área disciplinar inscriben su labor en el discurso académico y utilizan distintos formatos o géneros (artículos, ensayos, etc.) y canales (revistas especializadas, publicaciones de la cátedra) para comunicar un descubrimiento científico de diversa magnitud. De este último punto surge la cuestión de los géneros textuales y las características del saber académico.

Para que el saber o su autor/creador sea considerado "académico" no basta con que se genere en el ámbito formal de una universidad, también son necesarios atributos adicionales que detallamos a continuación:

-Persuasión: además de realizar un descubrimiento de algún tipo, el texto debe establecer la relevancia del mismo y ser persuasivo respecto de su legitimidad científica (Ramírez Gelves, 2007).

-Pretensión de objetividad: se trata de proveer suficientes evidencias al lector para que éste sienta que "la verdad se impone por si sola", con independencia de quién la enuncia o cómo: "Es decir, cuanto más provisto de carga subjetiva, más potencial de convencimiento logra un texto. Se trata de hacer que el lector suponga que ha tenido un encuentro genuino con una verdad objetiva la que no tendrá más remedio que aceptar" (Fastuca Fernández y Bressia s/f).

-Intertextualidad: el autor basa sus escritos en producciones teóricas y experimentales elaboradas por otros para apoyar sus argumentos y legitimar la relevancia de sus in- 
vestigaciones en determinado campos de estudios. De aquí que una de las convenciones de los textos académicos sea la cita de autores y el recurso argumentativo de presentar evidencias para convencer al lector.

Nos interesa conceptualizar la autoría académica no sólo en términos de la generación de materiales específicos de una disciplina por parte de un sujeto experto en el tema, sino también como parte de un proceso mayor que incluye la misma circulación de dichas producciones tanto por los canales tradicionales de las revistas (sean éstas impresas o no) como por vías menos convencionales pero cada vez más generalizadas. Nos referimos a redes sociales, blogs, plataforma de video, que permiten mayores intercambios con lectores especializados y público en general, y favorecen interacciones que la estructura del journal obstaculiza.

\section{Metodología y dispositivos de indagación}

La investigación consiste en un estudio de caso (EC) que explora las características propias de la creación y circulación de conocimiento por parte de tres autores. La indagación se basa en un análisis cualitativo del corpus constituido por sus producciones académicas en diversos ámbitos, y el contenido vertido en las entrevistas por parte de los tres sujetos en cuestión.

De acuerdo con Sautu (2010), el EC se ubica en el nivel microsocial de análisis en donde se pretende reconstruir los cursos de acción y las decisiones desde la perspectiva de un actor individual o, como en el presente estudio, de un grupo reducido de actores. Al respecto, tanto Stake (1999 y 2003) como Yin (1981) señalan la posibilidad de analizar más de un caso particular y enfocar la investigación en un pequeño manojo de casos que comparten características similares y permiten realizar un análisis transversal de dichos atributos.

En su tratamiento del estudio de caso, Archenti (2007) realiza una caracterización muy detallada que permite identificar rasgos predominantes en el presente estudio:

a) Tratándose de una o pocas unidades, el enfoque predominante en los EC es el análisis en profundidad; la búsqueda no se orienta hacia el establecimiento de regularidades empíricas sino hacia la comprensión del caso en su unicidad.

b) Resulta difícil realizar inferencias generalizantes a partir de una sola (o muy pocas) unidades, y

c) Los estudios se llevan a cabo, en la mayoría de los casos, en el escenario natural donde los actores se relacionan, dando lugar a los fenómenos que se intenta estudiar.

Tal como señala la autora, el objetivo de nuestra investigación no es efectuar generalizaciones a partir de la información recabada, sino abordar un fenómeno complejo como el de autoría académica en el marco de los nuevos medios en forma integral, mediante la combinación de diversas técnicas de estudio que Denzin y Lincoln (1994) denominan Bricolage por consistir en "un conjunto de piezas unidas, un tejido de prácticas que dan soluciones a un problema en una situación concreta [...], que cambia y toma nuevas formas a medida que se agregan nuevas herramientas, métodos y técnicas al rompecabezas". Se trata de una construcción flexible y cambiante que va mutando a medida que avanza el trabajo de indagación.

En términos epistemológicos, si bien el EC ha sido tradicionalmente cuestionado por su imposibilidad para generalizar abordajes o generar teoría, desde una perspectiva más "falsacionista" se valora la capacidad de los casos negativos para realizar modificaciones en 
las teorías o establecer límites a las generalizaciones. Es por esta razón que Archenti (2007) valora su fuerza empírica y define los estudios de caso en términos de su potencial para la inducción analítica que busca ilustrar, ejemplificar o eventualmente falsar postulados de una teoría general mediante la exposición de uno o algunos casos puntuales.

Otras propuestas consideran que a través de esta estrategia se genera una base empírica para conceptos y generalizaciones, convirtiéndola en un elemento esencial para la investigación social (Feagin, 1991), de modo tal que no sería correcto afirmar categóricamente la imposibilidad de generalizar a partir de un solo caso, en la medida en que esto es posible cuando se considera como caso ejemplificador. Si bien no provee elementos de prueba de enunciados generales, provee muchos indicios que pueden considerarse de apoyo a éstos.

De las cuatro razones que describe la autora, por las cuales una investigación se inclina por el diseńo de un EC, nos reconocemos en la tercera, puesto que otorga al estudio de caso la función de proveer de base empírica a una teoría existente, conteniendo atributos que ejemplifican o iluminan dicha teoría más general. Respeto de los tipos de EC, de los tres que describe Stake, el presente análisis puede ser tipificado como un EC Instrumental en el sentido de dar soporte y orientar la mirada sobre una serie ejemplos paradigmáticos que evidencian rasgos formulados por una teoría que los excede. Aquí es donde se superpone con otro tipo, el EC Colectivo, que busca generar comparaciones a partir de similitudes y distancias entre los ejemplos involucrados. En todo caso, y a los fines de pensar en la generación de resultados concretos:

Los investigadores utilizan dos estrategias para alcanzar los significados de los casos: la interpretación directa de los ejemplos individuales, y la suma de ejemplos hasta que se pueda decir algo sobre ellos como conjunto o clase. El estudio de casos se basa en ambos métodos. (Stake, 1999, p. 69)

En cuanto a los Instrumentos de indagación, el estudio se apoyó en una diversidad de dispositivos, buscando abarcar la variedad de producciones generadas (libros, capítulos, artículos impresos o digitales, intervenciones en blogs o redes sociales) y canales utilizados para su difusión y circulación (editoras impresas tradicionales, páginas web, blogs, plataformas web 2.0). Para ellos se realizaron:

Entrevistas a los actores: se contactó a cada actor en diversas oportunidades (por e-mail, en persona y/o telefónicamente) para ir reconstruyendo gradualmente los modos en que cada uno genera y da a conocer el producto de su trabajo en el ámbito de las universidades donde se desempeñan.

Análisis de contenido: tomamos algunos productos del trabajo académico a modo de "objeto testigo" para el posterior análisis no sólo de su contenido, sino también de las vías utilizadas para su difusión y circulación en la comunidad académica y el público en general.

En la siguiente sección, exploramos los desarrollos teóricos que sostienen la presente investigación y permiten formular tipologías y nuevos interrogantes.

\section{Escrituras digitales y saberes en circulación: una hipótesis y entrevistas a los actores}

Con el objetivo de analizar experiencias concretas de gestión y producción alternativa de conocimiento académico, realizamos entrevistas a un reducido grupo de investigadores/docentes universitarios que circulan sus producciones por diversos canales y plata- 
Mariana Ferrarelli / Modos de autoría en la era de la web participativa [...] $/ 71$

formas. La intención fue indagar en las motivaciones, posibilidades y ansiedades que las prácticas asociadas a lo digital generan en su trabajo cotidiano. Para ello abordamos las producciones académicas como objetos híbridos que, en tiempos de convergencia digital, circulan por canales alternativos, más abiertos y accesibles tanto al público en general como al especializado, lo cual dota al conocimiento producido de nuevos atributos. Los canales que denominamos alternativos al libro y el journal impreso incluyen portales académicos como Academia.edu, redes sociales (Facebook, Twitter), libros de libre circulación bajo licencias Creative Commons ${ }^{2}$, conferencias, charlas e incluso cursos completos accesibles desde YouTube, blogs personales, temáticos o de cátedra.

El estudio realizado se centró en las prácticas de producción y circulación de material de "autores académicos" que por su trayectoria y experiencia en el ámbito universitario pueden ofrecer interesantes y enriquecedores elementos que sustenten la hipótesis del trabajo en el sentido que señalábamos más arriba. Ellos son: Rebeca Anijovich (magíster en Formación de Formadores; docente de la Universidad de Buenos Aires y la Universidad de San Andrés); Patricia Nigro (doctora en Comunicación y docente de la Universidad Austral); Diego Levis (doctor en Ciencias de la Comunicación y docente de la Universidad de Buenos Aires). En todos los casos, se trata de personalidades de larga trayectoria en las casas de estudio de gestión privada y pública donde se desempeñan, y de autores que han publicado un volumen considerable de textos que circulan tanto en formato impreso (libros, capítulos o artículos) como digital (blogs, videos).

La multiplicidad que presenta cada uno en términos de los ámbitos, materiales y canales donde circulan sus producciones fue el criterio predominante para seleccionarlos como integrantes del pequeño grupo sobre el que realizaríamos la indagación. Se trata del mismo criterio que menciona Archenti (2007).

La selección del caso, entonces, nunca se realiza por azar (como en los métodos estadísticos), porque se parte de la no equivalencia entre los casos, que se destaca a través de la propuesta orientada a la comprensión de la especificidad de cada caso. El proceso de selección está basado en criterios teóricos, en experiencias de observación y en las expectativas depositadas en la unidad seleccionada, en términos de su potencialidad para proveer una base empírica relevante para la interpretación y comprensión del fenómeno estudiado. Siguiendo este planteo, cada caso es pensable como una construcción que es a la vez empírica y teórica: empírica porque está constituida por los elementos que se ofrecen a la observación y análisis directo, lo cual permite la recolección de información y su posterior estudio. Nos referimos a las entrevistas realizadas a los actores y a los contenidos que efectivamente se hallan impresos o publicados en la web y que fueron objeto de estudio. En cambio, el carácter teórico del caso reside en las relaciones de analogía, contraste y tensión con las tipologías propuestas que se establecen desde el análisis y el abordaje interpretativo. Aquí es donde ingresa al escenario de estudio la relación de los casos con categorías como el Paréntesis de Gutenberg, la flexibilización del concepto de autoría, la generalización del uso de redes sociales con fines de difusión del trabajo autoral, la producción de textos alternativos como videos, tuits o presentaciones interactivas que también generan conocimiento desde ámbitos antes impensados y que a su vez permiten interacciones con los lectores que pueden dialogar con el material y también realizar su aporte.

2 Creative Commons es una entidad sin fines de lucro, que promueve el intercambio y utilización legal de producciones de libre acceso. 


\section{Saber informal: remezcla, dispersión y colaboración}

Los casos analizados remiten a una flexibilización sobre cómo se define la autoría académica en términos de que ésta no sólo incluye artículos o libros impresos, sino también textos audiovisuales, sonoros, publicaciones digitales abiertas y nuevos géneros textuales (tuits, posteos en blogs o en redes como Facebook) que también generan conocimiento pero dotándolo de mayor informalidad, apertura y fluidez. Respecto de este punto se destaca el testimonio de Diego Levis cuando señala que "no tendría demasiada difusión si, a su vez, yo eso cuando publico algo ahí, no va a parar al Facebook, que esta es la verdad, hoy en día. [...] también, gracias a que algunos colegas, publican algunas cosas interesantes en Facebook, accedés a cuestiones interesantes, sean de los propios que los publican o de terceros". En los tres casos analizados se verifica que la inclinación por la utilización de redes sociales, especialmente Twitter y Facebook, proviene de la necesidad de darle mayor difusión de las producciones, así como de la imposibilidad del material impreso de circular con la misma fluidez e instantaneidad que el formato digital. Tal como indica Anijovich, esto se relaciona con el uso difundido de licencias Creative Commons con el objetivo de "blanquear, digamos, de quién es la producción, pero al mismo tiempo compartirla con el resto de la gente".

La bajísima rentabilidad que otorga la industria editorial a los autores es otro rasgo predominante que genera inclinación por los formatos digitales, tal como afirma Anijovich: "a mí no me preocupa la rentabilidad, porque salvo que seas Vargas Llosa o Borges, la rentabilidad es mínima, yo particularmente la rentabilidad de mis libros las uso para mantener mi página de Aulas Heterogéneas, por ejemplo." Este testimonio es respaldado por Levis y Nigro respectivamente.

Sin caer en un reduccionismo del canal, es preciso señalar los siguientes atributos presentes en la flexibilización del conocimiento gestionado mediante estos formatos:

-Fragmentación: es posible encontrar capítulos de libros y papers que circulan por la web con y sin autorización de autores, universidades o sello editor. Esto genera ansiedades en cuanto a la falta de control sobre el material propio publicado, pero también la certeza sobre la amplia difusión que proporciona la circulación por vías digitales. Patricia Nigro destaca una experiencia al respecto: "y ese cuadernillo una vez, una compañera lo encontró en una universidad, no quiero decir plagiado, porque va en contra de lo que pienso, pero prácticamente era lo mismo y no acreditaba autoría. Pero bueno, hay una alumna que por ahí se lo pasó a una profesora de colegio secundario, la profesora se lo pasó a otro, viste como es esto, es muy difícil, y ahora con lo digital, más todavía”.

-Interactividad: la mayoría de las plataformas web 2.0 permiten a cualquier usuario realizar comentarios, compartir la información, recortarla, agregar contenido y brindar feedback a su autor directamente. Aquí se destacan algunos comentarios recibidos en blogs/páginas web, readaptaciones o remix de contenidos publicados online, y uso de hashtags para agrupar publicaciones.

-Informalidad: el formato "micro" de algunas redes sociales que permiten compartir presentaciones gráficas, grabaciones de conferencias, etc., otorga niveles de informalidad en el trato entre colegas, o con el público en general, que antes eran impensables en la academia más rígida en sus roles y figuras.

"Autoría compartida" y multimodalidad: el saber circula en formato escrito pero también bajo formas audiovisuales, grabaciones, dibujos, infografías, en algunos casos emitidas por el público en tiempo real durante un evento o publicación. Es posible 
Mariana Ferrarelli / Modos de autoría en la era de la web participativa [...] /73 encontrar videos con conferencias o clases grabadas que están disponibles en las redes sociales, ediciones con fragmentos, o secciones de textos digitalizados a las que se suman las contribuciones de lectores y usuarios que sugieren nuevos textos y conexiones, aportan contenidos y conversan con el material publicado.

-Desguetificación: lo digital libera el saber del contexto de encierro al que estaba sometido cuando sólo circulaba en libros y reuniones para expertos. Si bien estas instancias aun existen, hay medios paralelos que facilitan la apertura y la libre circulación, en especial gracias a la masividad que proporcionan las redes sociales. En cuanto a la expansión de la difusión, Levis señala su experiencia: "lo publicó una universidad brasilera, junto con ALAIC, y sacaron pongamos 500 ejemplares. Yo lo publiqué en la web y llegó a tener, ahora no sé, hace tiempo que no lo veo, 40000 visitas". La contracara de este fenómeno es la emergencia indiscriminada de journals con variados niveles de calidad y rigurosidad científica, lo cual también es considerado como un riesgo en el nuevo panorama: "tenés que tener un criterio para determinar, si ese sitio web, lo que pública es serio o no", (Levis, 2017).

\section{Conclusiones}

Para el mundo académico que apoya su autoridad en el reconocimiento que le brinda el formato impreso, la cultura digital impone nuevos debates no solamente sobre el modo de distribuir el conocimiento generado, sino además sobre quién debe hacerlo y por cuáles canales. En la cultura digital, el libro es desplazado de su centralidad como portador de conocimiento y de la verdad acerca del mundo. Este descentramiento también produce un corrimiento de la academia como centro de producción y distribución del saber, y del autor como individualidad autorizada y experta en el campo delimitado por una disciplina. El texto escrito entendido como resultado del trabajo de un especialista en el tema es cuestionado por el paradigma digital, que acepta la participación colectiva y el intercambio entre iguales deconstruyendo jerarquías y devolviendo la producción cultural al terreo flexible y abierto de la colaboración, el diálogo y la poliautoría. En este sentido, emergen nuevos fenómenos que reposicionan el saber lectivo, académico y las prácticas a él asociadas:

-Des-academización de la producción de saber: las producciones que antes circulaban desde la academia y que ahora no encuentran lugar dentro de ella no se extinguen; por el contrario, se reproducen en masa, trascienden el claustro y circulan por fuera de la universidad para entrar a ella "desde los bordes". Esta descentralización, que se verifica en los modos de creación y circulación de conocimiento académico, va de la mano del mismo proceso que describen Gibbons et al (1997) respecto del pasaje del modo 1 al modo 2 de producción de conocimiento en las sociedades contemporáneas que se caracteriza "por la transdisciplinariedad y se institucionaliza en un sistema socialmente distribuido que es más heterogéneo y flexible. [...] Las universidades empiezan a reconocer que ahora sólo son un tipo de jugador, por importante que sea, dentro de un proceso enormemente expandido de producción de conocimiento". Si bien los procesos de producción de conocimiento exceden los fines de la presente investigación, no son independientes del modo en que se flexibiliza el concepto de autoría en la actualidad.

-Autoría expandida: si bien los temas siempre surgen en torno a una publicación central, rápidamente se producen conversaciones entre ese texto original y otros aporta- 
dos por los lectores/usuarios que tienden a expandir el universo temático y conectar con otras disciplinas.

- Simetría y colaboración: en el mismo foro intervienen especialistas de la academia y público menos especializado; los temas convocan tanto a expertos como a usuarios provenientes de otros campos, no sólo el académico, sino también el artístico, audiovisual o, dependiendo del tema, incluso amateur.

\section{Bibliografía}

—Anijovich, R. (2017). Entrevista personal: 16 de mayo de 2017.

-Archenti, N. (2007). "Estudios de Caso/s". En Marradi, A., Archenti, N., Piovani J. I. Metodología de las ciencias sociales. Buenos Aires: Emecé Editores.

—Barthes, B. (1971), "From work to text". En Philip Rice y P. Waugh (Eds.). Modern Literary Theory. London: E. Arnold.

—Bauman, Z. (2005). Modernidad Liquida. Buenos Aires: Fondo de Cultura Económica.

-Cope, B. \& Kalantzis, M. (2009). "Multiliteracies: New Literacies, New Learning". Pedagogies: An International Journal, 4(3), 164-195.

-Carlón, M. (2016). Después del fin. Una perspectiva no antropocéntrica sobre la posttv, el post-cine y YouTube. Buenos Aires: La Crujía Ediciones.

-Castellano, H. (2010). Enseñando con las TIC: integración de la tecnología educativa en el aula. Buenos Aires: Cengage Learning Argentina.

-Castells, M. (1997). La era de la información. Tomo 1. Madrid: Alianza.

—Castells, M., Fernández-Ardèvol, M. y Linchuan Qiu, J. y Sey, A. (2007). Comunicación móvil y sociedad, una perspectiva global. Barcelona: Ariel - Fundación Telefónica.

—De Echegaray, E. (1887). Diccionario general etimológico de la lengua española. Madrid: Álvarez Hermanos Impresores.

—Dussel, I. (2011). "La escuela y los nuevos medios digitales". En Artopoulos, A. La sociedad de las cuatro pantallas. España: Ariel - Fundación Telefónica.

—Fastuca Fernández, L. y Bressia, R. (s/f): "La escritura académica en la universidad". Disponible en http://www.uca.edu.ar/uca/common/grupo18/files/Definicion generos discursivos abril 2009.pdf

—Foucault, M. (1979). "What Is an Author?". En J. V. Harari (Comp.). Textual Strategies: Perspectives in Post-Structuralist Criticism (pp. 141-160). Nueva York: Cornell University Press.

—Genette, G. (1989). Palimpsestos. La literatura en segundo grado. Madrid: Taurus.

—Gibbons, M., Limoges, C., Nowotny, H., Schwartzman, H., Scott, P. y Trow, M. (1997). La nueva producción de conocimiento. La dinámica de la ciencia y ls investigación en las sociedades contemporáneas. Barcelona: Ediciones Pomares - Corredor.

—Jenkins, H. (2003). "Transmedia storytelling: Moving characters from books to films to videogames can make them stronger and more compelling." Disponible en http://www.technologyreview.com/biotech/13052

-Jenkins, H. (2006). Convergence Culture. La cultura de la convergencia en los medios de comunicación. Barcelona: Paidós. 
Mariana Ferrarelli / Modos de autoría en la era de la web participativa [...] /75

-Jenkins, J. (2008): "From production to Produsage: An interview with Axel Bruns (Part 1)". Disponible en http://henryjenkins.org/2008/05/interview with axel bruns.html

—Jenkins, H., boyd, D., Ito, M. (2016). Participatory Culture in a Networked Era. Cambridge: Polity Press.

-Landow, G. (2006). Hypertext 3.0. Critical Theory and new media in an era of globalization. Baltimore: Johns Hopkins University Press.

—Leal Fonseca, D. (2010). "Aprendizaje en un mundo conectado. Cuando participar (y aprender) es hacer clic". En Piscitelli A., Adaime, I., Binder, I. El proyecto Facebook y la posuniversidad. España: Ariel.

—Levis, D. (2017). Entrevista personal: 2 de agosto de 2017.

-Lyotard, F. (1984). The Postmodern Condition: A Report on Knowledge. Minneapolis: University of Minnesota Press.

-Maggio, M. (2012). Enriquecer la enseñanza. Los ambientes con alta disposición tecnológica como oportunidad. Buenos Aires: Paidós.

—Manovich, L. (2006). “¿Qué son los nuevos medios?”. En El lenguaje de los nuevos medios de comunicación. Buenos Aires: Paidós.

-Martín-Barbero, J. (1991). De los medios a las mediaciones. Méjico: Editorial Gustavo Gili.

—Martín-Barbero, J. (2002). "Jóvenes: comunicación e identidad". Disponible en http://www.oei.es/pensariberoamerica/ric00a $03 . h t m$

—Marradi, A., Archenti, N., Piovani J. I., (2007). Metodología de las ciencias sociales. Buenos Aires: Emecé Editores.

-Mombrú, A. y Margetic, A. (2013). El hacedor de tesis. Avellaneda: LJC Ediciones.

-Moreno, I. (2008): "Escritura hipermedia y lectoautores". En Tortorsa, V. (2008). Escrituras digitales. Tecnologías de la creación en la era virtual. Valencia: Publicaciones de la Universidad de Alicante.

—Nigro, P. (2017). Entrevista personal: 6 de julio de 2017.

-Ong, W. (2006). Oralidad y escritura. Tecnologías de la palabra. Buenos Aires: FCE.

-Piscitelli A. (2009). Nativos Digitales. Dieta cognitiva, inteligencia colectiva y arquitecturas de la participación. Buenos Aires: Santillana.

—Piscitelli A. (2010): 1 @ 1. Derivas en la educación digital. Buenos Aires: Santillana.

-Piscitelli A. (2011). El paréntesis de Gutenberg. Buenos Aires: Santillana.

—Piscitelli A., Adaime, I., Binder, I. (2010). El proyecto Facebook y la posuniversidad. España: Ariel.

—Ramírez Gelves, S. (2007). "Géneros discursivos y tipos de textos en el discurso académico". En CAICyT. Curso virtual para editores de revistas científicas, módulo 3.

—Reig Hernandez, D. (2010). "Un mundo de medios sin fin. Cambios en aprendizaje, Facebook y la apoteosis de las aplicaciones expresivas". En Piscitelli A., Adaime, I., Binder, I. El proyecto Facebook y la posuniversidad. España: Ariel.

-Rivera, J. (1997). Postales electrónicas. Ensayos sobre medios cultura y sociedad. Buenos Aires: Atuel. 
—RCUK Policy on Open Access and Guidance (2017). Disponible en: http://www. rcuk.ac.uk

—Rodríguez Reyes, C. (2005): "Hipertexto y literatura en Red. El relato digital, los escrilectores y la Cibercultura”. Revista TEXTOS de la CiberSociedad, 7. Temática Variada. Disponible en http://www.cibersociedad.net

—Rodríguez Ruiz, J. A. (2003). "Hipertexto, literatura y ciudad". Universitas Humanistica, pp. 53-67.

- Samaja, J. (2004). Proceso, diseño y proyecto en investigación científica. Cómo elaborar un proyecto sin confundirlo con el diseño ni con el proceso. Buenos Aires: JVE Ediciones.

- Samaja, J. (2005). Epistemología y metodología. Elementos para una teoría de la investigación cientifica. Buenos Aires: Eudeba.

—Sauerberg, O. (2009). "The Gutenberg Parenthesis - Print, Book and Cognition". Orbis Litteraturm, 64 (2), pp. 79-80.

—Sautu, R. (2010). “Sugerencias para la investigación científica en educación”. En: Wainerman, C., Di Virgilio, M. M. (Comps.). El quehacer de la investigación en educación. Buenos Aires: Manantial

—Schmucler, H. (1996): "Apuntes sobre el tecnologismo y la voluntad de no querer".Artefacto, (1).

—Selwyn, N. (2016): "Academic Work in the Digital Age". Disponible en https:// www.academia.edu/30388079/Academic Work in the Digital Age

-Scolari, C. (2013). Narrativas transmedia. Cuando todos los medios cuentan. Barcelona: Deusto.

—Scolari, C. (2012): “¿Existe un canon transmedia? Una propuesta de obras.” Disponible em http://hipermediaciones.com/2012/08/03/el-canon-transmedia/

—Scolari, C. (2011): "Narrativa transmedia, estrategias cross-media e hipertelevisión”. En Piscitelli, A., Scolari, C. y Maguregui, C. (Eds.). Lostología. Instrucciones para entrar y salir de la isla. Buenos Aires: Ed. Cinema.

—Stake, R. E. (2003). "Case Studies". En Ragin, Ch. y Becker, H. D. (Eds.). What is A Case?, Exploring the Foundation of Social Inquiry. Cambridge: Cambridge University Press.

- Stake, R. E. (1999). Investigación con estudio de casos. Madrid: Morata.

-Suber, P. (2012). Open Access. Massachusetts: MIT Press.

—Suber, P. (2003): "Not Napster for science".Disponible en : https://dash.harvard. edu/handle/1/4455490

-Tortosa, V. (2008). Escrituras digitales. Tecnologias de la creación en la era virtual. Valencia: Publicaciones de la Universidad de Alicante.

—Van Dijck, J. (2013). The Culture of Connectivity. New York: OUP.

-Yin, R. (1981). Case Study Research. London: Sage. 


\title{
La importancia de la interculturalidad en la clase de lengua extranjera
}

\author{
Mariana Elisa Castillo \\ mecastillo26@hotmail.com \\ María Julia Pourrieux \\ julipx@hotmail.com \\ Rec.17/04/17, Apr.09/06/17
}

\section{Presentación}

Desde nuestra experiencia como profesoras de Francés Lengua Extranjera -en adelante FLE-consideramos que procesar un texto implica la presencia de factores no sólo cognitivos, sino también pragmáticos. Cognitivos, en tanto supone una relación con los contextos lingüísticos y pragmáticos porque se refieren a los contextos culturales. Es por ello que el análisis de un texto no debe limitarse al estudio de sus unidades lingüísticas. En este sentido, coincidimos con Acuña y Legros, quienes a través de sus investigaciones afirman que: "es necesario tener en cuenta el contexto" (Legros y Acuña, 2006, p. 115) del aula para lograr la elaboración de una didáctica intercultural del texto que favorezca la interacción entre el texto y su intérprete. Siguiendo esta orientación, surgió la idea de privilegiar la lengua-cultura materna del aprendiente al momento del contacto con el texto, a través de un proyecto didáctico realizado con los alumnos del primer año del profesorado de Francés del Instituto de Enseñanza Superior Lola Mora.

A través de la producción de este dossier, buscamos priorizar la cultura materna de nuestros alumnos, dado que, la gran mayoría de los manuales de FLE presentan sus textos según una visión etnocentrista de los aspectos culturales favoreciendo particularmente la cultura francesa.

El documento elaborado tuvo como objetivo exponer las principales atracciones de San Miguel de Tucumán. Elegimos hacerlo bajo la forma de un circuito turístico, teniendo en cuenta las informaciones históricas, arquitectónicas, culturales y religiosas de los principales monumentos de nuestra ciudad, como así también de su gastronomía típica. Gracias a este tipo de actividades se privilegió el mundo conocido y vivenciado de los aprendientes $\mathrm{y}$, al mismo tiempo, se ayudó a los mismos a aproximarse de un modo diferente a las modalidades de co-significación y de co-construcción de un texto capaz de reflejar una fusión cultural.

Cabe destacar que esta actividad permitió a los alumnos del primer año de la carrera considerar la lengua, meta de una manera creativa; compartir emociones; debatir sobre situaciones problemáticas como así también encontrar soluciones en grupo; es decir, un verdadero trabajo en "tandem". Los jóvenes contaron además con sus profesores como co-protagonistas de este proyecto. 
Para ello, desde el punto de vista metodológico, nos hemos basado, por un lado, en el método comunicativo, el cual postula que la progresión de los contenidos debe elaborarse no sólo a partir de los aspectos lingüísticos, es decir el léxico y la gramática, sino también sobre la base de los aspectos funcionales del lenguaje, considerando a la escritura y a la palabra como una forma de actuar. Por otro lado, hemos enmarcado nuestro trabajo sobre la perspectiva accional. En este sentido, incorporamos las afirmaciones de Christian Puren que considera que la realización de acciones comunes, colectivas, en lengua extranjera favorece la interacción con el otro, a través de la puesta en marcha de una pedagogía por tareas, por proyectos. Esta perspectiva asume a los aprendientes como actores sociales capaces de desenvolverse en contextos preestablecidos.

\section{Hacia una pedagogía diferente de lo intercultural}

Para analizar el papel de la cultura en el procesamiento de un texto en FLE, retomamos los conceptos de Teresa Acuña y Denis Legros quienes postulan que

[...] la construcción de la significación de un texto es la resultante de una interacción entre el texto y sus unidades, y la base de conocimientos del lector, la cual está constituida por su sistema de conocimientos/creencias sobre el ámbito evocado por el texto. (Legros D, Acuña T. 2006. p.116)

Esta modalidad de acercamiento a lo intercultural, siempre presente en la clase de francés, trae como consecuencia una toma de distancia de la postura etnocentrista, a diferencia de la modalidad adoptada por muchos manuales de lengua extranjera. Nuestro objetivo en particular, es el de introducir a nuestros estudiantes en el conocimiento y descubrimiento de la lengua extranjera desde su propio entorno cultural y social. Es en ese sentido que solamente el mundo vivido, experimentado, conceptualizado y trabajado por la cultura dará sentido a la creación del conocimiento. De esta manera propusimos poner la lengua-cultura extranjera al servicio de nuestra realidad inmediata.

Como profesores de FLE, hacemos nuestra la propuesta según la cual: "[...] el referente de los significados del mundo no es el mundo, sino el mundo experimentado, el mundo conceptualizado por el espíritu, moldeado por la cultura." (Legros D, Acuña T. 2006. p.123). La experiencia de los alumnos para la construcción/reconstrucción de las representaciones de los temas trabajados en lengua extranjera ha sido el motor de esta actividad pedagógica. En efecto, hemos intentado contextualizar a través de una práctica social, la lengua-cultura meta en función de la realidad descripta, en este caso, la de la lengua-cultura materna.

La producción de textos en FLE para presentar ciertos rasgos de nuestro entorno ha implicado un contacto diferente con la lengua meta, a través del cual los alumnos se han visto obligados a expresar ciertos elementos que forman parte de su lengua materna, utilizando expresiones lingüísticas pertenecientes a la lengua extranjera en cuestión.

Esta tarea nos ha permitido, por un lado, abandonar una visión estática del lenguaje y del pensamiento, y por otro lado, relacionar categorías gramaticales a través de las cuales los pensamientos se transforman en palabras. Se trata pues de una forma especial del pensamiento que es movilizado durante la comunicación con el objeto de construir una significación determinada en un contexto específico. Esta idea puede ilustrarse a 
Mariana Elisa Castillo/ María Julia Pourrieux / La importancia de la intercultu- [...]/79 partir de la descripción de itinerarios, situación en la cual la lengua meta no dispone de elementos lexicales necesarios para hacer referencia, por ejemplo, a la palabra "cuadra", término sólo existente en la lengua materna. Esta situación presenta entonces ciertas dificultades sobre todo en la instancia de la producción, es decir, en la integración de significaciones en los contextos de la frase y del texto.

Hemos adoptado esta pedagogía focalizada en lo intercultural con el objeto de acordar más importancia a la carga cultural de la lengua materna, ya que esto determina el pensamiento de un individuo, a la vez que interviene en la comprensión y en la producción de un texto, para otorgarle una significación específica.

\section{Puesta en práctica de la tarea pedagógica. Características del grupo}

En lo que respecta a los estudiantes, se trata de un grupo que no es numeroso, se caracteriza principalmente por su heterogeneidad en relación al nivel de conocimientos lingüísticos, sus formaciones en otros ámbitos profesionales y en la edad. Los miembros de este grupo realizan sus estudios en una institución de enseñanza superior con el objetivo de ser profesores de francés. Es así que deben cumplir con una cierta cantidad horaria de clases en Francés Lengua Extranjera, completando su formación con cursos de formación pedagógica.

Con respecto a los conocimientos de lengua de los estudiantes, en general corresponden a un nivel A1 -avanzado-. Por lo tanto presentan dificultades en el aspecto fonológico, morfosintáctico, lexical, es decir, poseen un vocabulario más bien limitado a situaciones específicas. Sus intervenciones son poco fluidas al momento de comunicarse en clase, además, su participación no es muy espontánea.

La experiencia de producir textos para ser incluidos en un dossier nos ha permitido superar en cierto grado las dificultades antes descritas y reforzar no sólo los conocimientos presentados en clase, sino también otorgar a los estudiantes las herramientas necesarias para utilizar la lengua extranjera en una situación de comunicación lo más real posible.

\section{Objetivos de la actividad}

En este sentido, nos hemos propuesto los siguientes objetivos generales:

-Comparar las dos lenguas- culturas, presentes en la clase de FLE: la lengua-cultura materna y la lengua-cultura extranjera.

- Proponer a los alumnos una actividad motivadora para abordar los temas tratados en clase de lengua, tales como:

- Los lugares más importantes de la ciudad.

- La descripción de itinerarios.

- La descripción en los tiempos del pasado de los acontecimientos principales a fin de conocer los sucesos más relevantes de nuestra historia.

Los objetivos específicos en este caso serían los siguientes:

Que los alumnos sean capaces de:

-Desde el aspecto discursivo: realizar descripciones, relatos, argumentaciones y recetas de cocina. 
-Desde el aspecto lexical: buscar y analizar el vocabulario correspondiente a la descripción de diferentes aspectos de su ciudad: monumentos, sitios históricos, y gastronomía.

-Desde el aspecto morfosintáctico: conformar grupos nominales que comprendan diferentes tipos de expansiones. Estructurar frases simples correspondientes a un tipo de texto descriptivo.

-Desde el aspecto lingüístico: emplear la morfología correspondiente al futuro simple, a los tiempos del pasado (pretérito perfecto compuesto-pretérito imperfecto) y utilizar modos imperativo y condicional. Reforzar la morfología verbal del presente de indicativo con valor tanto actual como histórico.

\section{Descripción de la actividad}

Para llevar a cabo este proyecto, en un primer momento, los estudiantes han seleccionado algunos de los monumentos a presentar de la ciudad de San Miguel de Tucumán. Luego se han organizado en grupos de dos o tres personas. Cada uno ha elegido el sitio histórico a describir, en función de sus gustos e intereses personales. Posteriormente, los alumnos han buscado informaciones en sitios de Internet, en libros, en manuales y en otros medios. De esta manera han redactado textos breves referidos a los monumentos descriptos. Es así que los jóvenes han realizado un trabajo colaborativo de lectura, de selección, de resumen y eventualmente de traducción.

Luego, en situación de clase, el grupo ha organizado el itinerario a presentar, considerando la ubicación de cada monumento. Siguiendo esta pauta, se ha consensuado entre los participantes, elegir la oficina de turismo como referencia de la ciudad, y como punto de partida de los diferentes recorridos. En la fase siguiente, todas las producciones fueron reunidas en un solo documento, en función de un recorrido pre establecido. Para ello, cada grupo ha elegido un camino y ha descripto un itinerario a seguir para desplazarse de un lugar a otro en nuestra ciudad.

Finalmente en este cuadernillo, un estudiante que además es chef de cocina, ha trabajado los aspectos más salientes de la gastronomía de la región: sus platos típicos, sus ingredientes, sus recetas, como así también presentó una reseña de los vinos fabricados en el valle Calchaquí.

\section{Reflexiones finales}

Este trabajo ha sido motivador tanto para los estudiantes como para los profesores. La perspectiva de enseńanza propuesta, nos ha permitido por un lado, acercarnos a la cultura francesa a través de la mirada de los jóvenes del norte argentino. Y por otro lado, además de analizarla, hemos podido revalorizar la cultura argentina.

Para concluir, queremos insistir sobre la riqueza teórica de esta actividad, puesto que brinda la posibilidad de implicar al individuo en toda su dimensión cognitiva. De esta manera se evita la consideración del estudiante como una máquina que sólo procesa información. Esta metodología de trabajo nos permite además incluir en este proceso, los conocimientos previos e intercalar aspectos emotivos con paradigmas conceptuales presentes en la etapa del contacto entre la lengua-cultura materna y la lengua-cultura extranjera. 


\section{Bibliografía}

—Courtillon, J. (2003). Élaborer un cours de FLE. Paris: Hachette Livre.

-Denyer, M. (2005). Rond-Point II Guide péagogique. Barcelona: Difusión.

—Flumian, C., Labascoule, J., Royer, C. (2004). Rond-Point II, méthode de Français. Barcelona: Difusión.

—Flumian, C., Labascoule, J. y Royer C. (2004). Rond-Point II. Cahier d'exercices. Barcelona: Difusión.

—Gocel V, Francine C. (1993). “Lectures interactives en langue étrangère”. Hachette, (F autoformation). L'Information Grammaticale, (56), p. 57.

—Grégoire, M. (1995). Grammaire progressive du Français, niveau intermédiaire. Paris: CLE.

—Grégoire, M. (1997). Grammaire progressive du Français, niveau débutants. Paris: CLE.

—Legros, D. y Acuña T. (2006). "Variations interculturelles des représentations et du traitement des unités du texte". En Langages, 40e année, (163), Unité(s) du texte, sous la direction de Dominique Legallois. pp. 115-126.

—Moirand, S. (1990). Une grammaire des textes et des dialogues. Paris: Hachette FLE.

-Pendanx, M. (1998). Les activités d'apprentissage en classe de langue. Paris: Hachette FLE.

—Puren, C. (2003). La didactique des langues étrangères à la croisée des méthodes. Essai sur l'éclectisme. Paris: Didier.

-Rosen, E. (2009). La perspective actionnelle et l'approche par les tâches en classe de langue. LFDM Recherches et applications. Paris: CLE International.

—Vigner, G. (2004). La grammaire en FLE. Paris: Hachette. 



\section{Dossier}





\title{
CUADERNOS DE TRABAJO
}

\author{
CENTRO DE INVESTIGACIONES EN TEORÍAS Y PRÁCTICAS \\ CIENTÍFICAS \\ ESPECIALIZACIÓN EN \\ METODOLOGÍA DE LA INVESTIGACIÓN CIENTÍFICA \\ SEGUNDA ÉPOCA N ${ }^{\circ} 5^{1}$
}

Transformaciones en investigaciones y escrituras académicas

ISSN 1667-4995 / noviembre 2017

Publicación del Centro de Investigaciones en Teorías y Prácticas Científicas y de la Especialización en Metodología de la Investigación Científica del Departamento de Humanidades y Artes

Universidad Nacional de Lanús

1 Los artículos de este número de Cuadernos de Trabajo, fueron entregados al grupo editor entre febrero y septiembre de 2017, siendo aceptados para su publicación en octubre de 2017. 


\section{ÍNDICE}

\section{Presentación}

Cristina Ambrosini y Cecilia Pourrieux

E pur si riscaldato ( $\mathrm{Y}$ sin embargo se calienta)

Una aproximación a la ética profesional en el uso de los recursos naturales José Luis González

"Responsabilidad social en la gestión de la energía: el papel del Estado y de los funcionarios públicos involucrados. A propósito del aumento de las tarifas de gas natural. Su repercusión"

María de los Angeles Roveda y Matías Toso

Población ocupada, problemas de empleo, y condiciones de vida en Catamarca y Tucumán (1880-1970)

Ariel Osatinsky 


\section{Presentación}

Este Cuaderno de trabajo No 5 de la Segunda época está dedicado a la publicación de tres artículos, dos de los cuales están enmarcados en la Maestría en Gestión de la Energía del Departamento de Planificación y Políticas públicas de la UNLa, son dos trabajos elaborados en el marco del Módulo Ética de la gestión de la energía.

El artículo de José Luis González "E pur si riscaldato (Y sin embargo se calienta). Una aproximación a la ética profesional en el uso de los recursos naturales", recuerda la obra de teatro Galileo Galilei. Cuando el debate sobre los efectos perniciosos de la sociedad tecnocientífica, actualiza el mensaje de la obra de Brecht en vista a las consecuencias del uso intensivo de energías fósiles y sus consecuencias ambientales. Aparece el concepto de Ética profesional como un concepto compensatorio, o protésico, para ser tomado en cuenta por gerenciadores de empresas públicas y privadas del sector energético.

El artículo de María de los Angeles Roveda y Matías Toso "Responsabilidad social en la gestión de la energía: el papel del Estado y de los funcionarios públicos involucrados, a propósito del aumento de las tarifas de gas natural. Su repercusión" alude a un tema de alto impacto económico y social como es el precio del gas natural en tarifas que comenzaron a regir a partir de abril del año 2016. En estos dos artículos cabe destacar que los autores son profesionales involucrados en un área estratégica como es el de la gestión de la energía. En sus argumentos en defensa de la participación activa en los aspectos éticos a custodiar por los profesionales que intervienen evidencias la necesidad de superar la formación tecnocrática y cientificista, que se escuda en una supuesta necesidad de neutralidad para evadir la responsabilidad que les cabe en tanto ciudadanos. Finalmente, el artículo de Ariel Osatinsky, investigador del CONICET, analiza los cambios demográficos, laborales y en las condiciones de vida de las poblaciones de Catamarca y Tucumán en el período 1880-1970, vinculándolos con las transformaciones económicas. Si bien Tucumán tenía una economía más dinámica, Catamarca, con una estructura productiva tradicional y rezagada, tuvo una situación social menos crítica en diferentes etapas del período. De ahí, la importancia de examinar las transformaciones económicas y laborales. 



\title{
E pur si riscaldato (Y sin embargo se calienta) Una aproximación a la ética profesional en el uso de los recursos naturales
}

\author{
José Luis González² \\ jl.gonzalez.sosa@gmail.com
}

A mediados de la década de 1980 asistí a la obra de teatro Galileo Galilei del dramaturgo alemán Bertolt Brecht. En ese entonces, en Argentina, estaba todo en cuestión. Cursaba el colegio secundario y emergíamos de una dictadura criminal -con complicidades todos los estamentos sociales-; y tan poderoso resultó el mensaje de Galileo que recurrentemente regresaron a mi memoria los diálogos de este sabio medieval defendiendo su posición ética frente al poder.

La obra cuestionaba el conocimiento científico y su producción. Recreaba el juicio que debió afrontar Galileo Galilei (1564-1642), cuando la Inquisición juzgó su hipótesis astronómica -donde afirmaba que el planeta Tierra no es el centro del universo- y fue condenado a cadena perpetua. Vale recordar que sobrevolaba sobre él la amenaza de morir en la hoguera por hereje, como aconteció con el sacerdote y científico italiano Giordano Bruno en el año 1600. En Galileo Galilei, el autor realiza implícitamente una comparación con su presente, contraste que resulta efectivo porque el dramaturgo escribió la obra durante la ruptura de los desarrollos epistemológicos del siglo XIX, paradigma que observaba al saber científico como neutral e incontaminado. En este sentido, la Segunda Guerra Mundial, señaló el momento en que los avances tecnológicos transformaron el accionar de la ciencia aplicada en algo impredecible, brutal y hasta apocalíptico. A su vez, en forma metafórica, deja entrever un cuadro de situación que engloba a la censura y opresión que soportaron los intelectuales alemanes bajo el régimen Nazi; y en contrapartida, la proactividad de los científicos en un entorno libre (Estados Unidos) por crear y poner en funcionamiento el arma de destrucción masiva más poderosa de la historia: las bombas atómicas que destruyeron las ciudades de japonesas de Hiroshima y Nagasaki.

En la obra, Bertold Brecht, ${ }^{3}$ manifestó que la ciencia y el conocimiento no deberían servir al mantenimiento de un orden político, social y económico que atenta contra la ética y la justicia. Y que la ciencia, por el contrario, debería encargarse de velar por estos 2 Profesional del Centro de Energías Renovables del Instituto Nacional de Tecnología Industrial. Maestrando en Gestión de la Energía (UNLa); Licenciado en Periodismo (UNLZ); Posgrado en Desarrollo de Pymes (FI-UBA); y Posgrado en Economía Social y Desarrollo Local (UNGS).

3 Bertold Brecht, escritor y dramaturgo alemán de origen judío. En 1933, en pleno régimen nazi, debe abandonar Alemania. Se refugia en distintos países de Europa, hasta que decide radicarse en los Estados Unidos en 1941. En 1946 debe regresar a Europa víctima de otra persecución: es acusado y llamado a declarar frente al Comité para las Actividades Antinorteamericanas, liderado por el senador Joseph McCarthy. (este Comité logró exiliar a numerosos intelectuales con pasado o afinidades socialistas). Finalmente, en 1956, Brecht termina sus días en la Berlín Oriental bajo dominio soviético. 
principios. Hoy, el debate sobre los grises de la ciencia, mantiene absoluta vigencia, y uno de sus abordajes resulta el paradigma de desarrollo económico basado principalmente en el uso intensivo de energías fósiles y sus consecuencias ambientales. Tal es la gravedad del problema que, desde hace medio siglo, en todas las instituciones mundiales se alzan voces señalando que la velocidad de los cambios suscitados por el modelo de extracción, producción y consumo de la sociedad industrial (y post industrial) no se orientan hacia un desarrollo humano sostenible.

Como señala el sociólogo español Josetxo Beriain, los efectos producidos por la sociedad industrial:

[...] conlleva riesgos, contingencias, peligro para las existencias individuales y para la colectividad en cuanto tal. Así: la contaminación de los ríos derivada del vertido de los residuos, las industrias químicas, papeleras, siderúrgicas, cementeras, etc.; la contaminación del aire derivado de los gases liberados por el tráfico rodado y por la industria, la lluvia ácida que se extiende sobre los bosques de los países industrializados y que se produce como efecto de los vertidos gaseosos contaminantes, en definitiva, la producción industrial de efecto invernadero como peligro ecológico generalizado en el nivel planetario. (Beriain, 1996, p. 7)

En base a ésta aproximación, acercaremos una visión crítica sobre este paradigma de desarrollo que produce una coexistencia entre dos postulados contrapuestos de la Modernidad: la expansión de las opciones individuales y colectivas a nivel planetario; junto con la expansión de los riesgos que conlleva una racionalidad científica que no asegura la mera supervivencia de la especie humana sobre el planeta.

De manera conjunta -a través de una propuesta en debate, como es el concepto de ética profesional-, daremos cuenta de un mecanismo compensatorio (protésico si se quiere) como herramienta práctica en la toma de decisiones de funcionarios y gerenciadores públicos y privados respecto de los paradigmas imperantes en la gestión del desarrollo industrial con acento en las empresas del sector energético.

\section{Galileo Galilei: La obra}

Galileo Galilei, (Leben des Galilei en su título original) es una obra de teatro del dramaturgo alemán Bertolt Brecht escrita a finales de 1938. Entre 1945 y 1947 el autor escribió una segunda versión en colaboración con actor Charles Laughton; el cambio decisivo en dicha versión fue fruto de la conmoción que provocó la noticia de la utilización de la bomba atómica en Hiroshima.

En término generales, la obra está ambientada en la ciudad de Florencia (Italia) del siglo XVII, y se centra en los últimos años de vida del científico italiano. Sus protagonistas principales son Galileo, su hija Virginia, y su discípulo Andrea Sarti.

Cuando Galileo hace públicos sus descubrimientos sobre el sistema solar recibe la condena de la jerarquía eclesiástica porque sus investigaciones se oponen al dogma católico que postulaba al planeta Tierra como centro del universo (y por ende cuestionaba el saber/poder de la iglesia medieval). Bajo juicio y amenaza de la Inquisición romana, Galileo se retracta de sus escritos y renuncia a propagar sus investigaciones. La escena 
final de la obra refleja su aislamiento, donde recibe la visita de Andrea -convertido ya en científico-, al que hace entrega en forma clandestina documentos con nuevos descubrimientos científicos.

En primer término, uno de sus conceptos disparadores: entender a la ciencia como una disciplina sistémica que debe embeberse, arraigarse (en términos del humanista Karl Polanyi) en la sociedad donde se desarrolla. Es decir, entender a la ciencia como un producto más de la cultura donde evoluciona:

Hasta un comerciante en lanas, además de comprar barato y vender caro, debe ocuparse de que el comercio de la lana en general no sufra tropiezos. Y el cultivo de la ciencia exige, en este sentido, me parece, un coraje excepcional [...] (La ciencia) pretende proporcionar conocimientos a todos acerca de todas las cosas, y tiende a convertir a cada hombre en alguien que piensa y duda [...] Por eso nuestro arte cautivó a las multitudes. Nos arrancaron los telescopios de las manos y con él enfocaron a sus opresores. Y de pronto, aquellos hombres egoístas y brutales que se aprovechaban ávidamente de los frutos del trabajo científico, sintieron que la fría mirada de la ciencia detectaba y denunciaba una miseria milenaria pero artificial. Nos cubrieron entonces de amenazas y sobornos, que resultaron irresistibles para almas débiles. ¿Pero acaso podemos negarnos al pueblo y al mismo tiempo ser hombres de ciencia? (Brecht, 1985, p. 148)

Como Galilei desacralizó el conocimiento científico, Brecht propuso desneutralizarlo. Por eso su personaje afirmó que hasta un comerciante entiende que sus acciones individuales no deben comprometer al conjunto. Hoy día, desde disciplinas disímiles como la economía, la ecología y la teología postulan el reclamo de una ciencia integrada a su contexto: el premio Nobel Joseph Stiglitz en el prólogo de la obra clásica de Karl Polanyi La gran transformación, afirmó recientemente que las ideas principales del economista y sociólogo húngaro no han perdido importancia. Es decir, que la ortodoxia de la economía clásica de una sociedad regulada únicamente por la institución del mercado no encuentra sustento empírico a través de la historia:

Nuestra tesis es que la idea de un mercado autorregulado implica una utopía total. Tal institución no podría existir durante largo tiempo sin aniquilar la sustancia humana y natural de la sociedad; habría destruido físicamente al hombre y transformado su ambiente en un desierto. (Polanyi, 2007, p. 49)

La crítica de Stiglitz -basándose en Polanyi- va dirigida a los voceros del corpus de la economía neoclásica que permanentemente reconvierten los postulados clásicos de la economía de mercado, desligándola de su responsabilidad ante las cíclicas crisis económicas globales y a los problemas que enfrentan las economías en desarrollo, tanto en materia política, económica, como social y ambiental ${ }^{4}$.

El segundo pilar de la obra de teatro apunta al concepto de verdad y las consecuencias que acarrean escindirse de una mirada crítica respecto del accionar de la ciencia:

4 Basándonos en el filósofo Ricardo Maliandi, definimos el término ecología como toda forma de adaptación del hombre a la realidad circundante. 
Si los científicos se dejan atemorizar por los tiranos y se limitan a acumular el conocimiento por conocimiento mismo, la ciencia se convertirá en un inválido y las nuevas máquinas sólo servirán para producir nuevas calamidades. Tal vez, con el tiempo, ustedes lleguen a descubrir todo lo que hay para descubrir, pero ese progreso sólo los alejará más y más de la Humanidad. Y el abismo entre ella y ustedes, los científicos, puede llegar a ser tan profundo que cuando griten de felicidad ante algún nuevo descubrimiento, el eco les devolverá un alarido de espanto universal. (Brecht, 1985, p. 148)

Brecht con su crítica se anticipa categorías modernas. Hoy se denomina "cientificistas" a las posiciones epistemológicas que se caracterizan por mostrar a la producción del conocimiento científico como una actividad neutral desde el punto de vista valorativo. Esta idea es defendida por importantes científicos de renombre en nuestro medio, entre ellos, el epistemólogo Gregorio Klimovsky, y el célebre físico, filósofo y epistemólogo Mario Bunge:

Los investigadores en ciencias básicas son inocentes de los males sociales de nuestro tiempo, porque sólo procuran conocimiento y, mientras el conocimiento no se aplique a fines buenos o malos es moralmente neutral [...] como ya se ha dicho muchas veces, la ciencia básica es como un cuchillo que puede usarse sea para cortar una zanahoria o una cabeza humana, ambos son moralmente neutrales. Los científicos aplicados y los tecnólogos son bichos de una especie totalmente diferente: ellos sí pueden llegar a saber cómo hacer el bien o el mal. Pueden diseñar fertilizantes artificiales o proyectiles, medicamentos o gas nervioso, programas sociales o campos de exterminio. (Bunge, 1985, p. 191)

Por el contrario, Brecht enfatiza una mirada reflexiva que coincidiría con la del filósofo argentino Mario Heler, en su afirmación de que los científicos son responsables por los riesgos que asumen en el desarrollo de sus investigaciones y no deberían desentenderse de sus aplicaciones tecnológicas. Esta aproximación destaca la urgencia de reflexionar sobre la necesidad de asumir la responsabilidad que detenta el mundo científico, en cuanto actor destacado y, en última instancia, validador del discurso oficial y formadores de sentido común. Responsabilidad a sabiendas que los resultados de sus investigaciones presentarán una utilidad social que puede ser beneficiosa o perjudicial para el conjunto. Responsabilidad, entonces, que no se circunscribe en "iluminar" a la sociedad sobre los conocimientos científicos, sino también preocuparse por las consecuencias posibles de las aplicaciones sociales de estos conocimientos.

Resulta sorprendente percibir que mentes brillantes adhieran aún a silogismo como el de la "neutralidad del cuchillo o del martillo". En este contexto, hasta la jerarquía eclesiástica en octubre de 1992, reconoció los errores cometidos por el tribunal eclesiástico que juzgó los postulados científicos de Galileo Galilei. Este proceso de aggiornamiento continuó, y hoy permite que el Papa Francisco I divulgue una encíclica, en la cual reflexiona sobre la responsabilidad de la ciencia respecto del desarrollo. En la misma esboza el concepto de riesgo -clave en las últimas décadas-, y descarta la posibilidad de una "ciencia neutra" con "aplicaciones buenas o malas": 
La humanidad ha ingresado en una nueva era en la que el poderío tecnológico nos pone en una encrucijada. Somos herederos de dos siglos de enormes olas de cambio: el motor a vapor, el ferrocarril, el telégrafo, la electricidad, el automóvil, el avión, las industrias químicas, la medicina moderna, la informática y, más recientemente, la revolución digital, la robótica, las biotecnologías y las nanotecnologías. [...] La tecnología ha remediado innumerables males que dañaban y limitaban al ser humano [...] Pero no podemos ignorar que la energía nuclear, la biotecnología, la informática, el conocimiento de nuestro propio $\mathrm{ADN}$ nos dan un tremendo poder. [...] ¿En manos de quiénes está y puede llegar a estar tanto poder? Es tremendamente riesgoso que resida en una pequeña parte de la humanidad. (Francisco I, 2015, pp. 79, 80 y 81 )

La encíclica Papal acompaña el debate la vulnerabilidad de la condición humana y los riesgos que puede generar la sociedad industrial en un desarrollo no sustentable; peligros generalizados a nivel planetario. A estas amenazas debemos sumar los individuales: el peligro de accidentes en centrales de generación eléctrica (térmicas, fundamentalmente), o por el privilegio en el uso de aviones, trenes o automóviles accionados por carburantes fósiles, entre otros. Mediante estos artificios tecnológicos la sociedad industrial y sus externalidades, crea y expande nuevos riesgos en su desarrollo. El filósofo alemán Ulrick Beck denominó a este estadio "sociedad del riesgo", destacando el nuevo carácter de la Modernidad y con ello la precariedad de los nuevos parámetros de confianza y seguridad. En forma paralela, el sociólogo alemán Niklas Luhmann postuló que a mayor desarrollo científico-tecnológico mayor riesgo, actualizando el clásico "Mito de Prometeo" y su re-lectura "El aprendiz de brujo" que metaforizan el peligro de conceder a la sociedad industrial un poder que no sabe usar.

\section{Para una gestión sustentable de la tecnología}

Nuestra civilización tecnológica se construyó sobre tres pilares: las ideas de la Ilustración (según el filósofo Inmanuel Kant "una radicalización de la Modernidad"), el sistema de producción y el dominio de las máquinas (de vapor, luego térmicas y nucleares). Estos tres pilares combinados forjaron una sociedad a nivel mundial que expandió las posibilidades humanas y liberó para la producción industrial todas las potencialidades energéticas de la naturaleza almacenadas en los combustibles fósiles durante milenios. Así, nuestra actual civilización se sustentó en ideas y formas organizativas propias con base material es la instauración de un particular régimen energético. Tanto es así que, uno de los métodos propuestos para medir el grado de desarrollo de una civilización dada es su consumo energético (Escala de Nicolái Kardashov, 1964). Por este artificio mensuramos que el hombre primitivo consumía de 2000 a 3000 calorías diarias; en comparación con las 300.000 calorías per cápita que utilizan las sociedades más desarrolladas tecnológicamente (el indicador integra el consumo de transporte y artefactos de industria y recreación). El resultado es que, en menos de 200 ańos de sociedad industrial, hemos consumido gran parte de los recursos que la naturaleza tardó millones de años en generar.

Es sabido que nuestra matriz energética primaria se sustenta en un $80 \%$ en el uso de combustibles fósiles y, más allá del debate de la tendencia a la escasez de estos recursos, 
se agregan las consecuencias ambientales por su uso indiscriminado; a todas luces el problema económico, social y político más grave que debemos afrontar como comunidad mundial en este siglo.

Cómo en la época de Galileo Galilei, cuyo saber disruptivo llevó a que se lo tildara de loco y hereje; hoy, después de décadas donde el discurso de la problemática Medio Ambiental y el avance del Cambio Climático pareció pertenecer a "fundamentalistas" de la ecología y científicos subvalorados, el fenómeno finalmente acaparó la atención del mundo científico tecnológico y de la opinión pública para incorporarse a la agenda política internacional. Y como no es posible recurrir al dogma de la Inquisición para eludir el debate; -con estudios concluyentes- son pocos los que todavía pueden dudar de su característica antropogénica.

\section{Epur si muove}

"Y sin embargo se mueve" (en español), es la frase que se adjudica a Galileo Galilei luego de conocer el fallo condenatorio del tribunal de la Inquisición. "Y sin embargo se calienta", podríamos parafrasear hoy, en atención a la problemática ambiental.

Desde comienzos de la década de 1960 se levantan voces que advierten sobre la falta de sustentabilidad en el uso de los recursos. Pero el tema cobró estado público e ingresó por primera vez en la agenda política a partir de la publicación de "Los límites del crecimiento", investigación realizada por un equipo interdisciplinario del Massachusetts Institute of Technology (MIT) en 1972 a pedido del Club de Roma ${ }^{5}$. La investigación consistió en utilizar el método de Dinámica de Sistemas para examinar en un contexto mundial las interdependencias e interacciones de cinco factores críticos. En sus conclusiones, los autores manifestaron:

Si se mantienen las tendencias actuales de crecimiento de la población mundial, industrialización, contaminación ambiental, producción de alimentos y agotamiento de los recursos, este planeta alcanzará los límites de su crecimiento en el curso de los próximos cien años. El resultado más probable sería un súbito e incontrolable descenso tanto de la población como de la capacidad industrial. (Meadows, Randers y Behrens, 1972, p. 40)

El informe no hizo otra cosa que poner en términos científicos las consecuencias incontrolables de un modelo de desarrollo industrial si la ciencia, la política, la economía y la cultura no unían conocimiento teórico y práctico en una propuesta sistémica para evitar el colapso del planeta. La denuncia mundializada por el informe operó también como catalizador de las críticas al modelo de desarrollo hegemónico que se generaban desde distintas disciplinas; y resultó un hito significativo para que decisores (políticos y del mundo de la ciencia) reflexionaran sobre sus prácticas ${ }^{6}$. En el ámbito regional, las denuncias motorizadas por el Club de Roma encontraron su contrapropuesta en estudios como el "Modelo Mundial Latinoamericano" liderado por la Fundación Bariloche,

5 Asociación civil compuesta por destacados empresarios, científicos y políticos de las principales naciones industrializadas del último cuarto del siglo XX.

6 El ex presidente Juan Domingo Perón estuvo al tanto del debate, ya que, en su regreso a la Argentina tras 17 años de exilio, mencionó en uno de sus primeros reportajes la importancia de la cuestión ambiental en un país que estaba al borde de la guerra civil. 
donde se critica la visión desarrollista de "Los límites del crecimiento" porque proponía una inmovilización de la actividad industrial -y demográfica- de todos los países. Saco a luz estos dos estudios, porque más allá de sus diferencias, las considero propuestas honestas: ambos informes contemplaban aproximaciones que unen lo profesional y lo humano (en un sentido cívico y cosmopolita), proponiendo a la investigación científica como una instancia de reflexión social que involucra teoría y praxis.

La agenda de los decisores mundiales lentamente fue haciendo foco en el tema. En este sentido, una de las propuestas más importantes fue la formación del Grupo Intergubernamental de Expertos sobre el Cambio Climático (IPCC), establecido en 1988 conjuntamente por las Naciones Unidas y la Organización Meteorológica Mundial $(\mathrm{OMM})$, usina que ha proporcionado a los responsables de la política mundial las evaluaciones científicas y técnicas de mayor autoridad y objetividad.

Se confirma que el calentamiento en el sistema climático es inequívoco y que muchos de los cambios observados no han tenido precedentes en los últimos decenios a milenios: la atmósfera y el océano se han calentado, los volúmenes de nieve y hielo han disminuido, el nivel del mar se ha elevado y las concentraciones de gases de efecto invernadero han aumentado. Cada uno de los tres últimos decenios ha sido sucesivamente más cálido en la superficie de la Tierra que cualquier decenio anterior desde 1850. (IPCC 2013, p. 5)

El organismo en el mismo informe señala que para contener el cambio climático, sería necesario reducir de forma sustancial y sostenida las emisiones de gases de efecto invernadero (IPCC, 2013, pág. 19). El aumento de las emisiones antropogénicas se da tanto por la quema de combustibles fósiles (un $40 \%$ de las emisiones globales totales), como por el crecimiento de las áreas urbanas y los cambios en el uso de la tierra (deforestación); ya que al disminuir la vegetación, la biosfera, los sumideros y los océanos, absorben menor cantidad de gases de efecto invernadero de la atmósfera. ${ }^{7}$

En el ámbito energético, los expertos Jean-Michel Glachant y Christopher Jones fundamentan en sus trabajos la transición europea hacia una matriz energética descarbonizada -con el máximo de eficiencia energética y basada en fuentes renovables-, a partir de los estudios del IPCC:

[...] el IPCC considera que se debe realizar un recorte de entre el $85 \%$ y el $50 \%$ en las emisiones, en comparación con el año 2000. Para 2050 es necesario limitar el calentamiento entre 2,0 y 2,4 grados. [...] Independientemente de la distribución exacta, para la Unión Europea, esto se traduce básicamente en una reducción de las emisiones en al menos un $80 \%$, y probablemente más. (Glachant \& Jones, 2012, p. 4)

\section{Hacia una ética profesional de los decisores en materia energética}

Entre las medidas propuestas para cambiar la dinámica de deterioro, la última cumbre mundial sobre el Cambio Climático celebrada en París en abril de 2016, cerró un

7 Los principales gases emitidos son el Dióxido de Carbono (CO2), el Metano (CH4) y el Oxido Nitroso (N2O). Los dos últimos tienen un efecto invernadero muy superior al $\mathrm{CO} 2$, pero su presencia en la atmósfera es muy inferior al Dióxido de Carbono. 
acuerdo que -de concretarse- será revolucionario: los 195 países reunidos firmaron como meta obligatoria que el aumento de la temperatura media del planeta quede a final de siglo por debajo de los dos grados respecto a los niveles preindustriales. El compromiso reclama que cada país reduzca sus emisiones de gases de efecto invernadero nacionales; y como medida principal, promueve la utilización de las energías renovables como el recurso más importante para hacer frente a ésta situación. En un nivel macro, estos compromisos internacionales son fundamentales; como sustancial resultaría la generación de políticas locales que viabilicen estos acuerdos. No obstante, todo este arsenal de propuestas quedaría en buenas intenciones si -en un nivel inmediatamente inferior-, no son acompañados por agentes públicos y privados que los materialicen en su cotidiano accionar.

En este punto entra en juego una instancia de reflexión social que se propuso para la investigación científica, y que debe extenderse a otros estadios de la intervención tecno-social. En un nivel inmediatamente inferior desde el corpus teórico, pero determinante desde lo fáctico, ubico la reflexión ético profesional que se propone a los decisores en materia de desarrollo industrial. Siguiendo a Ambrosini, entendemos a la: "[...] ética profesional como el conjunto de normas y códigos que regulan una disciplina o actividad de individuos con conocimiento académico dentro de un trabajo remunerado y especializado." (Ambrosini, 2011, p. 26). Siendo la adopción de éste tipo de ética, un nivel superador que no se limita al respeto de los códigos propios de la actividad, ya que además involucra cuestionar sus fundamentos y revisar las razones para la aplicación de normas morales en el campo profesional determinado.

Un concepto clave que acompaña al ejercicio de la ética profesional, es el concepto de "contingencia". La contingencia se contrapone al dogma técnico a lo establecido, y pone de manifiesto que existe una opción, "[...] que puede cambiar lo que es observado (la situación) y los que observan." (Beck 1996). La contingencia afirma que las decisiones sobre los posibles cursos de acción que se decidan conllevan un riesgo. Y que aún, la inacción y la falta de decisión, comportan un riesgo inmanente.

[...] la transición de la sociedad industrial a la sociedad del riesgo se consuma como no deseada, como no pretendida, y adopta la forma de una dinámica modernizadora independiente [verselbstiindigt] bajo el modelo de consecuencias colaterales latentes. (Beck 1996, p. 22)

En la actual transición de paradigmas, podemos argumentan que el riesgo de la inacción resulta muy costoso en el curso de la actual sociedad industrial. En este sentido, la ética profesional se presenta como una herramienta dinámica y proactiva, que da cuenta del saber cómo un campo interdisciplinario -ya que entiende que las normas y códigos sectoriales parcelan la aproximación teórica y práctica a los objetos, y resultan insuficientes para afrontar nuevos desafíos globales como el cambio climático-. Por este motivo, la ética profesional, puede contribuir a dinamizar las reflexiones y prácticas en la toma de decisiones de los funcionarios responsables en materia energética. Una herramienta para que piensen sus acciones dentro de un sistema superior, y no entender la aplicación ética únicamente como premio o castigo, sino como herramienta que contribuye a la convivencia y a la sustentabilidad del sistema social y su medio ambiente.

En este sentido, para un decisor de políticas sectoriales, no puede dar lo mismo motorizar proyectos de fuentes de energía renovables que fósiles; industrias contami- 
nantes o tecnologías sustentables. Y que, más allá de intereses coyunturales, debe actuar una instancia de facticidad normativa que integre una aproximación teórica -y a la vez cotidiana- respecto de lo bueno y lo malo en nuestra conducta a través de la reflexión. Instancia que debe contemplar al conocimiento disciplinario dentro de un sistema; no como una receta, sino como apelación a una reflexión sistémica que involucra teoría y praxis. En paralelo, integrar la ética profesional desde la ética cordial, concepto que propone la filósofa espańola Adela Cortina para centrar el discurso en la necesidad de evaluar la ambivalencia de las tecnologías y el impacto en la vida social. Propuestas que promueven la resignificación de los valores políticos que motorizan a la ética, y recreando la idea del Contrato Social, con especial atención a la dimensión social y su entorno biológico.

En síntesis, una ética -en tanto, disciplina-, que involucre conocimientos filosóficos y técnicos fundamentales para la supervivencia de nuestro medio social y físico. Una herramienta, un mecanismo compensatorio superador de los distintos desequilibrios antropogénicos producidos por un -hasta el presente- irreflexivo desarrollo industrial.

\section{Bibliografía}

-Ambrosini, C. (2011). "Ética profesional. La ética como mecanismo compensatorio en el mundo globalizado". Revista Perspectivas metodológicas, (11), pp. 23-38.

-Ambrosini, C. (2012). "Responsabilidad en la Sociedad del Riesgo. Cenando sobre el Costa Concordia”. (Manuscrito no publicado). Recuperado de http:// www.scielo.org.ar.

—Beck, U. (1996). "Teoría de la sociedad del riesgo". En Beriain, J. (Comp.). Las consecuencias perversas de la modernidad. Modernidad, contingencia y riesgo (pp. 201-222). Barcelona: Editorial Anthropos.

—Beriain, J. (1996) "El doble «sentido" de las consecuencias perversas de la modernidad”. En Beriain, J. (Comp.). Las consecuencias perversas de la modernidad. Modernidad, contingencia y riesgo (pp. 7-29). Barcelona: Editorial Anthropos.

-Brecht, B. (1985). Galileo Galilei. Buenos Aires: Ediciones Teatro Municipal General San Martín.

-Bunge, M. (1985). Seudociencia e ideología. Madrid: Alianza.

-Cortina, A. (2007). "Éthica Cordis". Isegoría. Revista de Filosofía Moral y Politica, (37), pp. 113-126.

-Fernández Buey, F. (2014). "Brecht sobre Galileo y la responsabilidad del científico”. Revista de la Asociación de Directores de Escena (152).

-Francisco I. (2015) "Carta Encíclica Laudato si (Sobre el cuidado de la casa común)”. Buenos Aires: Ediciones de la Legislatura Porteńa.

—Glachant, J. M \& Jones, C. (2012), "Why and How the European Union Can Get a (Near To) Carbon-Free Energy System in 2050?” Recuperado de http:// ceepr.mit.edu/files/papers/2010-002.pdf

—Herrera, A. y Scolnick, H. (2004) “¿Catástrofe o Nueva Sociedad? Modelo Mundial 
Latinoamericano 30 años después”. Buenos Aires: HED-America Latina.

—IPCC Grupo Intergubernamental de Expertos sobre el Cambio Climático (2013). En "Cambio Climático 2013. Bases físicas". Recuperado de www.ipcc.ch/pdf/ assessment-report/ar5/wg1/WG1AR5 SummaryVolume FINAL SPANISH. pdf

— Losey, J. (1974). "Galileo". Inglaterra. Película dirigida por Joseph Losey. Recuperado de www.youtube.com/watch? $\mathrm{v}=$ w1I $2 \mathrm{RsH}-\mathrm{c}$

—Luhmann, N. (1996). "El concepto de riesgo". En Beriain, J. (Comp.). Las consecuencias perversas de la modernidad. Modernidad, contingencia y riesgo. (pp. 123-153). Barcelona: Editorial Anthropos.

-Maliandi, R. (2007). Etica, dilemas y convergencias: cuestiones de la identidad, la globalización y la tecnología. Buenos Aires: Biblos-UNLa.

—Meadows, D., Randers, J. y Behrens III, W. (1972). Los límites del crecimiento, México: Ediciones Fondo de Cultura Económica.

-Polanyi, K. (2007) La gran transformación. Los orígenes políticos y económicos de nuestro tiempo. Buenos Aires: Ediciones Fondo de Cultura Económica. 


\title{
Responsabilidad social en la gestión de la energía: el papel del Estado y de los funcionarios públicos involucrados. A propósito del aumento de las tarifas de gas natural. Su repercusión
}

\author{
María de los Angeles Roveda ${ }^{1}$ \\ mariaroveda7@gmail.com \\ Matías Toso ${ }^{2}$ \\ matiastoso@gmail.com
}

Al inicio del presente año, el Ministerio de Energía y Minería de la Nación, mediante Resoluciones $\mathrm{N}^{\circ} 28 / 2016$ y $\mathrm{N}^{\circ} 31 / 2016$, dispuso la determinación de nuevos precios en Punto de Ingreso al Sistema de Transporte (en adelante PIST), las tarifas de transporte y distribución para el gas natural, que comenzarían a regir a partir del $1^{\circ}$ de abril del año 2016, aplicándose a las diferentes categorías de usuarios - con bonificaciones para aquellos que registraran un ahorro igual o superior al $15 \%$ con respecto al mismo período del año anterior $-\mathrm{y}$ los criterios de elegibilidad para ser beneficiarios de una tarifa social.

Dicho acto Estatal implicó el inicio de un debate que trascendió el aspecto meramente económico para diversificarse en numerosas aristas con implicancias sociales, éticas y "estéticas" que serán luego abordadas. Sin embargo, es importante destacar aquí que los argumentos o motivos oficiales del cambio del cuadro tarifario no refirieron a tal debate, entre ellos pueden destacarse:

Que para promover inversiones en exploración y explotación de gas natural a fin de garantizar su abastecimiento y de emitir señales económicas claras y razonables, resulta necesario implementar un nuevo esquema de precio de gas natural en el PUNTO DE INGRESO AL SISTEMA DE TRANSPORTE, que tenga por objeto tanto la incorporación de reservas, como el aumento en la producción doméstica de gas natural, y que permita lograr que en el me-

1 Abogada egresada de la Universidad Nacional de La Pampa. Integrante de la cátedra "Derecho de Minería y Energía" de la Facultad de Ciencias Económicas y Jurídicas de la Universidad Nacional de La Pampa. Estudiante Maestría en Gestión de la Energía de la Universidad Nacional de Lanús

2 Abogado egresado de la Universidad Nacional de La Pampa. Integrante de la cátedra "Derecho de Minería y Energía" de la Facultad de Ciencias Económicas y Jurídicas de la Universidad Nacional de La Pampa. Estudiante Maestría en Gestión de la Energía de la Universidad Nacional de Lanús 
diano y largo plazo dichos precios resulten de la libre interacción de la oferta y la demanda, conforme fueron concebidos originariamente en los términos del último párrafo del Artículo 83 de la Ley Nº 24.076.

Encabeza entonces los argumentos la invocación de la seguridad jurídica con la protección de las inversiones realizadas en esta materia, con el consecuente aumento de las reservas, volumen de gas domiciliario y, en definitiva, el tan anhelado autoabastecimiento en condiciones de mínima regulación (oferta-demanda).

Qué, con igual criterio, resulta necesario establecer Precios por Cuenca para el gas no contabilizado a abonar por las Empresas distribuidoras a los efectos de reducir el impacto de dicho costo sobre las tarifas finales a aplicar a los usuarios.

Evidentemente, el espíritu de la normativa intenta poner en valor la realidad geográfica y política de un país Federal que consta de diferentes provincias con realidades climáticas absolutamente distintas, advirtiéndose - a priori - que una "tarifa plana" para toda la república no sería justa, ni razonable ni inclusiva.

Que en la formulación de la medida resulta oportuno contemplar un esquema que procure un consumo racional del gas natural, incentivando el ahorro para generar un uso responsable y eficiente de los recursos y, en tales términos, se prevé el otorgamiento de beneficios para todos aquellos consumidores residenciales de gas natural que reduzcan su demanda, conforme el mecanismo que por la presente se implementa.

Aquí aparece el concepto de uso racional y eficiente y la indiscutida necesidad de promover el ahorro de un recurso tan necesario como escaso, de manera tal qué, en miras a lograr este objetivo, pareciera ser que un aumento en el precio posee una vinculación directa con el ahorro. Esta vieja falacia no se ajusta a la realidad de los efectos reales de esta normativa, más aun, tal como se explicará en adelante, su planteo inadecuado puede llegar al fin contrario al buscado.

Qué, asimismo, resulta necesario considerar situaciones particulares que justifiquen la aplicación de una tarifa final diferenciada a aquellos usuarios que, por su menor capacidad de pago, se vean imposibilitados de abonar los Cuadros Tarifarios Finales correspondientes a su área.

Finalmente, aparece la nota social de reconocer que determinados sectores o personas pese a la necesidad de uso de gas natural, no podrían afrontar el nuevo cuadro tarifario, por lo que anuncia una tarifa final diferencial que -en concepto- los incluya en el servicio. Este pequeño resumen, que a modo introductorio presenta: a) una decisión política y administrativa, b) la problemática ante la cual surge esta decisión y c) los fundamentos oficiales -es decir la visión de quien la adopta- plasmando los objetivos generales de la normativa, es a nuestro entender el disparador de un profundo e histórico debate que se extendió durante todo el año 2016 y posee un trasfondo ético que en pocas decisiones administrativas ha quedado tan expuesto. 


\section{El día después - primeras repercusiones}

Apenas dispuesta su publicación, las voces no se hicieron acallar y lo que en letras y discursos muy solubles quedó reflejado en la realidad fue un jumping (salto) de una tarifa casi en su totalidad subsidiada por el Estado a un $1000 \%$ de aumento de aquélla, sin subsidio alguno, salvo para un sector muy específico de la sociedad. Es así como luego de numerosos reclamos sociales y de los gobernadores de las provincias, se llega a un acuerdo (que se luce en las Resoluciones $\mathrm{N}^{\circ}$ 99/16 y No 111/16, Ministerio de Energía y Minería), donde se dispuso un tope del $400 \%$ para los usuarios residenciales y $500 \%$ al incremento del precio del gas de usuarios Pymes, Comercio y Hoteles.

Desde el gobierno nacional se admitió cometer "errores" y con el fin de llevar tranquilidad a los argentinos se dictaron esas medidas paliativas -entiéndase al daño colateral de la medida auto generada- y según se dijo en algunos medios, el "costo fiscal" de estos topes fue de unos 2250 millones de pesos que no pagaron los "clientes" y que asumió el Estado Nacional.

Los funcionarios públicos involucrados hicieron sentir sus distintos pareceres: por un lado la voz escrita del Ministro de Energía y Minería mediante el dictado de la Resolución $\mathrm{N}^{\circ}$ 28/2016 que tuvo que verse modificada necesariamente por el desagrado que ocasionó la medida tomada, llevada al comentario de "errores" por parte del Ministro del Interior de la Nación y aquellos sectores políticos (gobernadores, senadores y diputados) que consideraron a aquella primigenia norma como: un "aumento desmedido en la tarifa de los servicios públicos"; "un ataque al bolsillo de los trabajadores y queremos manifestarle nuestra preocupación por el alcance de estas medidas", "los aumentos desmedidos de las tarifas están causando consecuencias muy graves a usuarios particulares y a las empresas que integran el sector productivo" (sic, http://www.infobae.com/2016/06/02/1815708 -el-gobierno-admitio-errores-y-hoy-hara-anuncios-atenuar-la-suba-del-gas).

Incluso no faltó quien realizando un análisis agudo de la aplicación al caso concreto de los topes tarifarios demostró que favorecía a los sectores más pudientes a la vez que inducía al derroche o uso irracional.

Para graficar eso puede apelarse al ejemplo de la familia tipo del interior (con dos calefactores, un termotanque y cocina) con ingresos del orden del salario mínimo vital y móvil que de pagar 250 pesos, comienza abruptamente a pagar 1000 aun cuidando el recurso y ahorrando racionalmente su uso.

Del otro lado, en el Nordelta, una familia adinerada para quien el pago de las tarifas de los servicios públicos no representa un porcentual significativo de sus ingresos (con calefacción central y demás artefactos) pero que además tenía el hábito de climatizar su piscina con caldera los fines de semana para practicar natación, pagaba 500 pesos por mes.

Pues bien, esta familia, pagará 2000 pesos por mes, pero como esta tarifa implica un "tope", probablemente no se inclinará hacia el ahorro, sino que la pileta estará climatizada los 7 días de la semana por el mismo precio, aumentando el consumo en contra de los fines buscados por la normativa.

Este ejemplo de fantasía sirve para demostrar las asimetrías ocasionadas por una medida que no pudo prever los efectos inmediatos y comenzó a colocar parches.

Aquí no se discute que el Estado lleve adelante activas políticas públicas, pero si se debe tener presente que, a la hora de planificar y posteriormente ejecutar, la mirada debe centrarse en el reparto de cargas y beneficios de todos los sectores sociales. 
Citando a la Dra. Cristina Ambrosini en Responsabilidad en la Sociedad del Riesgo. Cenando sobre el Costa Concordia. En Homenaje a Mario Heler señala:

[...] el principio de justicia atiende al reparto de cargas y beneficios esperando que sean equitativos y que no perjudiquen a los menos beneficiados socialmente $[\ldots]$ (Ambrosini, inédito)

Y en el caso, la responsabilidad del Estado y de los funcionarios público involucrados no puede dejar de lado ese principio ético de justicia, quien como experto debe tomar decisiones sobre la gente en vista al beneficio común.

Parafraseando el concepto de la Dra. Ambrosini, vale decir que, así como el componente ético implica visualizar una protección a los menos beneficiados en toda medida impulsada, no debe tampoco pasar desapercibido lo cuestionable que puede resultar favorecer excesiva e injustificadamente a los sectores más pudientes.

\section{Para innovar, volvamos a las fuentes}

La globalización supone una ideología que clama por menos Estado, es decir, menos política, menos ciudadanía y más mercado (Ambrosini, 2011)

En países con economía de mercado, como el caso de Argentina, el principio es que la prestación de un servicio debe ser retribuida al prestador mediante el pago de una tarifa.

Ahora bien, esa retribución para lograr un equilibrio debe estar regulada, teniendo en cuenta parámetros tales como:

Cantidad de dinero que deben abonar los usuarios por el servicio; Inversiones atendiendo a la calidad del servicio hacia el usuario; $y$, La renta que el prestador obtiene por la prestación del servicio.

Y el principio básico es que la tarifa debe ser justa y razonable. He aquí el planteo ético: no se trata de discutir si una herramienta de neto resorte del Poder Ejecutivo (en el caso, aumento de tarifas) puede ser aplicada o no por aquel, sino cómo repercute sobre el usuario o consumidor, en cuanto a su calidad de vida que hace a la dignidad de la persona.

El problema que enfrenta el usuario es que las facturas de gas que llegan son impagables, clubes, escuelas, universidades, resienten calidad para las actividades sociales, deportivas y académicas -incluso en algunos casos llegando a cerrar sus puertas-; las industrias suspenden a sus empleados; los comercios reducen personal o trasladan los costos a los consumidores, quienes a su vez deben abonar la factura para no verse perjudicados por posibles cortes del suministro. No es un dato menor que la Corte Suprema de Justicia de la Nación al tomar intervención en este tema, le pidió al Estado Nacional tres (3) cosas; a saber: el desarrollo de audiencias públicas, gradualidad y previsibilidad en el cuadro tarifario a adoptar. Nótese el rol asumido por el máximo Tribunal reencauzando la cuestión en una visión diametralmente opuesta a la inicial: la de los usuarios involucrados que pasaron de ser sujetos pasivos de una medida a ser el centro ético del sistema a quienes se les debe participación (a través de audiencias) y respeto (a través de la gradualidad que le permita planificar y prepararse para afrontar los costos del servicio). 
En definitiva, puso fin a un gran círculo vicioso, donde el rol del Estado y los funcionarios públicos involucrados juegan un papel preponderante. Así en ajustada síntesis expuso aquel Alto Tribunal':

El cuadro tarifario del servicio de gas previsto por las resoluciones 28/16 y 31/16 del Ministerio de Energía y Minería de la Nación es nulo, pues no se respetó el derecho a la participación de los ciudadanos bajo la forma de audiencia pública previa.

La realización de una audiencia pública es exigible para determinar el precio en el punto de ingreso al sistema de transporte de gas - PIST—, pues, hasta el momento en que efectivamente se determine sobre la base de la libre interacción de la oferta y la demanda, tal como es el objetivo del decreto 181/2004, deviene razonable que el análisis de su costo se efectúe juntamente con la revisión de tarifas.

En materia tarifaria la participación de los usuarios de un servicio público no se satisface con la mera notificación de una tarifa ya establecida, sino que es imperativo constitucional garantizar la participación ciudadana en instancias públicas de discusión y debate susceptibles de ser ponderadas por la autoridad de aplicación al momento de la fijación del precio del servicio.

La participación de los usuarios con carácter previo a la determinación de una tarifa constituye un factor de previsibilidad que integra el derecho a una información "adecuada y veraz" —art. 42, Constitución Nacional-y constituye un elemento de legitimidad para el poder administrador, cuya responsabilidad de garantizar el derecho a la información pública está estrechamente vinculado al sistema republicano de gobierno.

Por aplicación de un sentido de justicia, el precio final que se les fije a los usuarios del servicio de gas como consecuencia de la sentencia que anula el cuadro tarifario establecido por las resoluciones 28/16 y 31/16 del Ministerio de Energía y Minería de la Nación en ningún caso puede arrojar como resultado sumas mayores a las que dichos actores hubiesen debido abonar por la estricta aplicación de aquél, considerando la tarifa social.

Todo reajuste tarifario debe incorporar como condición de validez jurídica, conforme con la previsión constitucional que consagra el derecho de los usuarios a la protección de sus "intereses económicos" -art. 42, Constitución Nacional-, el criterio de gradualidad, que constituye la expresión concreta del principio de razonabilidad.

El Estado debe velar por la continuidad, universalidad y accesibilidad de los servicios públicos, ponderando la realidad económico-social concreta de los afectados por las decisiones tarifarias, con especial atención a los

3 Publicado en: LA LEY 23/08/2016, 23/08/2016, 11 - LA LEY2016 -E, 46 - LA LEY 25/08/2016 , 1, con nota de Federico M. Álvarez Larrondo; Gabriel H. Quadri, Diego A. Giussani y Carlos M. Mighetti; Juan Vicente Sola; Silvia B. Palacio de Caeiro; Estela B. Sacristán; y Francisco Verbic y José María Salgado; DJ14/09/2016, 29 - LA LEY 12/09/2016 , 4, con nota de Leandro J. Giannini; LA LEY 2016 -E , 216, con nota de Leandro J. Giannini. 
sectores más vulnerables, y evitando el perjuicio social provocado por la exclusión de numerosos usuarios como consecuencia de una tarifa que, por su elevada cuantía, pudiera calificarse de "confiscatoria", por detraer de manera irrazonable una proporción excesiva de los ingresos del grupo familiar.

Las audiencias públicas previas a la toma de decisiones en materia tarifaria correspondiente al servicio de gas deben realizarse para todos los tramos que componen la tarifa final, incluyendo el precio en boca de pozo - PIST-, transporte y distribución (del voto del Dr. Maqueda).

En materia de servicios públicos, no es admisible desvincular el "costo global de la prestación" de la "capacidad de pago de los usuarios", pues así como es lógico suponer que el monto de las tarifas se calcula en función del financiamiento del servicio, también lo es deducir que un cálculo tarifario desmesurado o irrazonable que deba ser solventado únicamente por los usuarios generará altos niveles de incobrabilidad y terminará afectando la calidad y continuidad del servicio (del voto del Dr. Rosatti).

En mira a garantizar la razonabilidad de la tarifa de un servicio público esencial es imprescindible que exista una clara diferenciación de sectores y regiones, con atención especial a los más vulnerables, pues la garantía de igualdad no impide que el legislador contemple en forma distinta situaciones que considere diferentes, en la medida en que las distinciones o exclusiones se basen en motivos razonables y no en un propósito de hostilidad contra determinada persona o grupo de personas o en un indebido privilegio (del voto del Dr. Rosatti).

El panorama previo al dictado del fallo mencionado planteaba de plano la cuestión ética que graficamos mediante titulares periodísticos, y la repercusión del tema objeto del presente estudio:

Neuquén: cierran una escuela por el aumento del gas. (Infobae 24 de mayo de 2016)

Primera cautelar contra el aumento de la luz: fue en San Martín y benefició a una clínica. (Infobae 24 de mayo de 2016)

A la luz de las velas, en contra del aumento en la electricidad.(Infobae 26 de mayo de 2016)

Intendentes de la costa le reclamaron al Gobierno bajas en la tarifa del gas. (Infobae 28 de mayo de 2016)

Cambios en tarifas de gas: tope de $400 \%$ de suba para residenciales y de $500 \%$ para comercios en todo el país. (Infobae 3 de junio de 2016)

Para el Gobierno, "si no hay aumento en las tarifas, el costo de la energía se pagará con inflación. (Infobae 8 de agosto de 2016, a)

La Justicia Federal frenó los aumentos del gas en todo el país. (Infobae 8 de agosto de 2016, b) 
La otra cuestión a tener presente es como afecta a un país la quita drástica de subsidios y cómo repercute ante los diferentes actores sociales (industrias, residenciales), su influencia en el consumo, empleo -porque no se debe olvidar en la ecuación que toda suba drástica siempre implica recortes en la parte más fina del hilo -, y la sustentabilidad de aumentar gradualmente las mismas.

La situación pone en el tapete dos principios constitucionales: la razonabilidad de la norma y la prestación del Estado de los servicios públicos (luz, agua, gas) para el desarrollo humano, máxime los avances tecnológicos de indudable impacto sobre la mejora de la calidad de vida.

En el escenario actual de la sociedad argentina, se hace necesario una tarifa sustentable a la que se tiene que arribar, pero un "per saltum" -por utilizar un parangón jurídico- sin escalas previas en los hechos hace casi impagable por buena parte de los usuarios esos aumentos "irrazonables" dando lugar a argumentar que el acceso al servicio público se torna casi ilusorio. Se estaría afectando la calidad de vida (derecho humano primario) que el Estado debe proteger. Nadie discute que la modificación del cuadro tarifario es necesaria, por el retraso en los precios de los servicios públicos afectados, pero la medida no puede darse de extremo a extremo, sino que se debe ajustar en cuanto a adaptación en el tiempo, teniendo en cuenta la situación geográfica, los grupos vulnerables o de riesgo, impacto en el consumo, entre otros.

El problema ético que aquí se avizora es que el aumento en la tarifa de gas se ha hecho para atender a una problemática real que consiste en el bajísimo precio de gas en boca de pozo, que no cubre siquiera los costos de producción, y conspiran contra el aumento de las reservas y soberanía energética, sin contemplar el reparto de cargas y beneficios en la gestión de la energía.

La responsabilidad social se ve flanqueada con este tipo de situaciones, donde el papel del Estado y sus funcionarios públicos juegan un rol primordial, dado que el Estado debe velar por los intereses de sus habitantes evitando toma de decisiones que puedan afectar sus derechos fundamentales.

Por más importancia que revista el problema a resolver, no puede ser solucionado con la creación de un problema mayor, o bien que afecte a un número mayor de personas con un grado de vulnerabilidad superior. Esto no resiste ningún análisis ético ni tampoco estético.

\section{Conclusión}

La integración de los intereses económicos de los usuarios, por un lado, de los productores de gas, por el otro, tuvo que ser resuelta por el Estado Nacional quien no resultó ser en este especial caso un tercero imparcial, sino más bien un actor más con intereses económicos bien definidos en juego. Es decir, con la necesidad de reducir el costo de importación de combustibles en resguardo de las divisas de la Nación como condición necesaria para estructurar una nueva etapa en Argentina.

En este contexto, en orden de importancia económica, los usuarios en la mentada estructura de poder son los rezagados y quienes clamaron por una protección y el establecimiento de una tarifa que sea justa y razonable; a lo cual debe agregarse: accesible. 
Las tarifas contemplan los valores técnicos que deben ser razonables para permitir la recuperación de los costos y afrontar inversiones, pero la revisión de los cuadros tarifarios le atañe tanto al Estado, los concesionarios y a los usuarios.

Como ya bien lo expresó Agustín Gordillo en su Libro "Cien Notas de Agustín: notas asistemáticas de un lustro de jurisprudencia de derecho administrativo: "De otra forma habría que concluir en que la expresión 'justas y razonables' importa solo una aspiración programática, una simple intención de píos deseos".

En el caso la Corte Suprema recordó que se ha omitido el derecho fundamental consagrado constitucional y legalmente, la audiencia pública previa al dictado de una norma general de tanta trascendencia como la reestructuración tarifaria.

El Estado tiene entre sus atribuciones revisar las tarifas, pero ello no significa que la norma legal que lo habilita a esos fines implique "una concesión unilateral, espontánea y graciosa del príncipe" (Agustín Gordillo), sino que como guardián de los intereses de los habitantes del país debe velar por ellos y protegerlos comportándose de buena fe.

La prestación del servicio público es una cuestión de política económica, de competencia de decisión de oportunidad, mérito y conveniencia del poder público. Como decisión política no es aprobable o reprobable siempre y cuando se respete la ecuación contractual entre la prestadora del servicio y los usuarios.

Ergo, la responsabilidad social en la gestión de la energía por parte del Estado y los funcionarios públicos que planifican y ejecutan las políticas públicas no se encuentra en tela de juicio, ni se reprocha la misma, si y solo si se vela por los intereses económicos de los dos sujetos contractuales (prestador-usuario).

Ahora bien, si el aumento de las tarifas ha sido solamente para favorecer a una de las partes el contrato (prestador), la cuestión ética se impone necesariamente en cuanto que aquellas no son justas y razonables ni proporcionales; sin perjuicio que se establezcan excepciones al principio de igualdad por razones de equidad para proveer a los usuarios que no pueden pagar el aumento tarifario (léase tarifa social).

La potestad tarifaria tiene en miras consideraciones de interés público, y en el crecimiento institucional y maduración democrática, se debe tomar la experiencia de gas para aplicar el principio ético a los procedimientos futuros de sinceramiento de tarifas.

\section{Bibliografía}

—Ambrosini, C. (2011). “Ética profesional. La ética como mecanismo compensatorio en el mundo globalizado". pERSPECTIVAS 11

—Ambrosini, C. (S/f). "Responsabilidad en la Sociedad del Riesgo. Cenando sobre el Costa Concordia". En AA. VV. Homenaje a Mario Heler. (inédito)

-Poder Judicial de la Nación. Cámara Federal de la Plata. Sala II: "Centro de Estudios para la Promoción de la Igualdad y la Solidaridad y Otros c/ Ministerio de Energía y Minería s/ Amparo colectivo.

—Gordillo, A. (1999). "Cien notas de Agustín: notas asistemáticas de un lustro de jurisprudencia de derecho administrativo". Fundación de Derecho Administrativo. Buenos Aires. 1999. Recuperado en: http://www.gordillo.com/ pdf cien/agustin2.pdf

—Sacristán, E. B. (2006). "Cuestiones políticas, politización, publicación, 

pueblificación en las tarifas de los servicios públicos". Primeras Jornadas ItaloArgentinas de Derecho Público. Revista Rap digital N³50. 2007. pp. 393-406. Recuperado en: http://www.estelasacristan.com.ar/publicaciones/Cuestiones $\% 20$ politicas $\% 20$ politizacion $\% 20$ publificacion $\% 20$ en $\% 20$ las $\% 20$ tarifas $\% 20 \mathrm{de} \% 20$ los\%20servicios\%20publicos.pdf

\section{Fuentes}

—http://www.infobae.com/2016/05/24/1813795-neuquen-cierran-una-escuela-el-aumentodel-gas. 24 de mayo de 2016, a.

- http://www.infobae.com/2016/05/24/1813815-primera-cautelar-contra-el-aumento-la-luzfue-san-martin-y-beneficio-una-clinica. 24 de mayo de 2016, b.

-http://www.infobae.com/2016/05/26/1814203-a-la-luz-las-velas-contra-del-aumento-laelectricidad. 26 de mayo de 2016.

- http://www.infobae.com/2016/05/28/1814692-intendentes-la-costa-le-reclamaron-algobierno-bajas-la-tarifa-del-gas. 28 de mayo de 2016.

- http://www.infobae.com/2016/06/03/1815900-cambios-tarifas-gas-tope-400-subaresidenciales-y-500-comercios-todo-el-pais. 03 de junio de 2016.

-http://www.infobae.com/politica/2016/07/08/para-el-gobierno-si-no-hay-aumento-en-lastarifas-el-costo-de-la-energia-se-pagara-con-inflacion. 8 de agosto de 2016, a.

-http://www.infobae.com/economia/2016/07/07/la-camara-federal-de-la-plata-declaro-nulaslas-resoluciones-que-autorizan-la-suba-del-gas. 08 de agosto de 2016, b. 



\title{
Población ocupada, problemas de empleo, y condiciones de vida en Catamarca y Tucumán (1880-1970) ${ }^{1}$
}

\author{
Ariel Osatinsky \\ aosatinsky@yahoo.com.ar
}

\section{Introducción}

A comienzos del siglo XXI, la provincia de Catamarca se distinguía de las restantes del Noroeste Argentino (NOA) por sus menores niveles de pobreza (Bolsi et al., 2009), mientras que Tucumán, con una economía de mayor magnitud, tenía un porcentaje superior de hogares pobres. Diversos trabajos muestran de qué forma Tucumán experimentó en las décadas de 1980 y 1990 transformaciones económicas más regresivas y un mayor deterioro laboral que Catamarca (Osatinsky, 2009; 2012; 2013; 2013a).

Sin embargo, Tucumán, que había tenido desde fines de siglo XIX la economía más dinámica de la región, y Catamarca, con una estructura productiva tradicional y muy rezagada, tenían a comienzos de la década de 1980 niveles cercanos de pobreza estructural ${ }^{2}$.

En ese sentido, el objeto de este artículo es analizar los cambios más relevantes que experimentaron las poblaciones ocupadas de ambas provincias, los problemas de empleo que sufrieron, y el impacto que tuvieron en las condiciones de vida en ese largo período. Se parte del supuesto de que las dificultades laborales constituyen un importante componente del vínculo que existe entre la economía y la pobreza.

Estas provincias tuvieron en el tiempo un desarrollo económico disímil. Durante el siglo XVIII y las primeras décadas del XIX Catamarca y Tucumán tuvieron rasgos comunes como ser la diversificación que caracterizaba sus producciones, y cierto dinamismo en las relaciones comerciales. Siendo de mayor dimensión la economía tucumana, la brecha que la separaba en lo productivo de Catamarca no era tan grande.

Sin embargo, a partir de la segunda mitad del siglo XIX, mientras que Tucumán experimentó una penetración más profunda de las formas de producción capitalistas, Catamarca conservó una estructura más tradicional en su economía.

Las diferencias no se restringen al plano económico. Mientras que Catamarca posee una superficie de $102.602 \mathrm{~km}^{2}$, su población en el período bajo estudio, no alcanzó a 200.000 habitantes. Por el contrario Tucumán, en una superficie de $22.524 \mathrm{~km}^{2}$, tenía a mediados del siglo XX casi 600.000 habitantes, superando los 700.000 desde 1960, siendo la provincia con mayor densidad de la región.

1 Agradezco las sugerencias y comentarios de los evaluadores anónimos de la revista.

2 En 1980 Catamarca y Tucumán tenían 38\% y 37\% de sus hogares con NBI (Censo Nacional de Población y Viviendas, 1980). 


\section{2/ Perspectivas Metodológicas /20/Vol. II /noviembre, Año 2017}

El artículo posee diversos apartados, que se corresponden con el estudio de los aspectos socioeconómicos mencionados en la etapa del modelo agroexportador, y en las distintas fases de período de industrialización sustitutiva de importanciones.

\section{Conceptos y metodología}

La pobreza es un fenómeno que estuvo siempre vinculado a la economía. "Los cambios en la pobreza resultan, en gran medida, de cambios que tienen lugar, a diferentes niveles, en el conjunto de la economía" (Lo Vuolo et. al., 2004, p. 125). En ese sentido,

[...] más allá de la heterogeneidad espacial asociada a las condiciones naturales o la herencia histórica, el factor clave de las desigualdades se asocia a la propia lógica de funcionamiento del sistema económico. (Méndez, 1997, p. 322)

Si nos interrogamos acerca de los elementos que se encuentran en ese vínculo que existe entre las transformaciones económicas y la pobreza, no se puede dejar de tener presente a la población con problemas de empleo. Una persona sin ocupación no participa del proceso de creación de bienes y servicios y, por lo tanto, queda marginada de la distribución de riqueza que surge en el proceso de producción. A su vez, aquellos que se encuentran ocupados, pueden sufrir condiciones precarias de empleo como así también disminuciones en su salario real (Lindenboim, 2005). Se trata de situaciones o cambios regresivos en el mercado de trabajo, que agravan las condiciones de vida de una determinada población.

Un concepto importante en esta investigación es el de población económicamente activa (PEA), la cual está conformada por el: [...] conjunto de personas que [...] tiene una ocupación o que, sin tenerla, está en condiciones de trabajar y la busca activamente" (Neffa, 2005, p. 73). Es decir que la PEA incluye a los desocupados, conjunto formado por toda persona que, sin tener ocupación, la busca de manera activa.

Las transformaciones laborales, en general, son consecuencias de cambios que acontecen en la actividad económica, concepto que está asociado a la producción de bienes y servicios de una determinada economía. El conocimiento de dicha producción implica examinar la estructura económica de una determinada región, la cual se compone de una gran cantidad de actividades que pueden ser agrupadas en los sectores primario, secundario y terciario ${ }^{3}$.

La actividad económica, al producir los bienes y servicios que posee una determinada sociedad, es la fuente generadora de los ingresos con los que cuenta esta.

[...] la forma de distribuir y el destino dado a la riqueza generada no conforman un acto posterior a la producción: son una parte intrínseca de la actividad económica. Por lo tanto, es esta una parte central de la explicación de la pobreza, la ocupación y la desocupación. (Lindenboim, 2005, p. 14)

\footnotetext{
3 El sector primario agrupa al conjunto de actividades vinculadas a la obtención de recursos naturales (agricultura, ganadería, minería, etc.). El secundario a las actividades ligadas a la transformación de recursos naturales (industria, construcción, electricidad, gas y agua). Por último, el sector terciario agrupa a las actividades de servicios (transporte, comercio, comunicaciones, financieras, administración pública, etc.).
} 
Por ello, se describen los cambios o transformaciones que más relevantes que tuvieron lugar en la composición de las estructuras productivas de Catamarca y Tucumán, ya que estos implican modificaciones en la distribución de lo producido, siendo a su vez factores ligados directa o indirectamente a los procesos causales del deterioro laboral y social de las poblaciones.

En el presente estudio, debido a que no se cuenta con mediciones de la pobreza para los casos de Tucumán y Catamarca en el período previo a 1980, se utilizaron algunos indicadores vinculados a las condiciones de vida con el objeto de poder comparar la situación social que tenían las poblaciones de ambas provincias. Estas comparaciones se llevaron a cabo observando qué semejanzas y diferencias tuvieron en aquel entonces las poblaciones y hogares de estas provincias en relación al analfabetismo, a los materiales del piso y el techo de las viviendas y otras características como la tenencia de red de agua, y en referencia a la mortalidad infantil. Este último indicador tal vez sea el que mejor haya reflejado en aquellos años previos a 1980, la situación social de las poblaciones bajo estudio, como lo demuestran los estudios de Longhi para el Norte Grande Argentino (Longhi, 2009).

En la investigación se consideró tanto la evolución de la ocupación como también, para ciertos períodos, de la desocupación. El seguimiento del nivel de empleo permite conocer la dinámica que tiene en diferentes momentos la demanda de empleo, y por lo tanto, el requerimiento de fuerza de trabajo. A su vez, se analizó la evolución y distribución de la población ocupada en las actividades económicas que conforman las economías provinciales bajo estudio, en pos de observar las consecuencias en el plano laboral de las transformaciones económicas.

En cuanto a las transformaciones productivas, se tuvo en cuenta la dinámica de ambas economías provinciales en el contexto de los cambios económicos que acontecían a nivel nacional. En ese sentido, se trabajó con la composición que el Producto Bruto Geográfico $(\mathrm{PBG})^{4}$ de Catamarca y Tucumán tenía en determinados años, con el propósito de distinguir las actividades que se destacaron o fueron creciendo en importancia, y aquellas que sufrieron crisis y disminuyeron su participación en la estructura productiva. Asimismo, consideraron indicadores que reflejan las dinámicas que tuvieron en el período bajo estudio actividades que se destacan por el peso que tenían en las economías y el mercado de trabajo de ambas provincias: el sector agropecuario, la industria, el comercio y la construcción, o los servicios vinculados a la administración pública.

En cada uno de los apartados del artículo, se describen los cambios demográficos de Catamarca y Tucumán, por la vinculación que poseen con las dinámicas económicas y laborales.

Cabe destacar que en la segunda mitad de siglo XIX, Catamarca y Tucumán tuvieron dinámicas demográficas muy distintas. En el período 1858-1869 la población tucumana se incrementó casi un 30\%, mientras que Catamarca mantuvo prácticamente la misma cantidad de habitantes.

Probablemente estos cambios estuvieron vinculados a las diferencias que empezaban a tener el desarrollo económico de una y otra provincia. Tucumán, con una producción azucarera en expansión y vinculada de manera más directa con el Litoral, se transformó en un polo de atracción para diversos pobladores de la región del Noroeste. La economía tucumana abandonaba paulatinamente su carácter comercial-ganadera, en el pasaje hacia una producción en la que sería dominante la manufactura azucarera (Parolo, 2008).

4 El PBG es la denominación que posee el Producto Bruto Interno a nivel provincial. 
Por su parte, Catamarca tenía una producción agropecuaria de menor escala y sus vínculos comerciales con los diferentes mercados eran menos intensos que el caso tucumano, lo que implicaba la existencia de menos fuentes de empleo, lo cual se transformaba en un factor expulsor de población.

Estas dinámicas demográficas se profundizarían en las últimas décadas del siglo XIX, período en el que la Argentina se insertaba en el mercado mundial como productor y exportador de productos agropecuarios, consolidando esa orientación económica en el período 1880-1930, conocida como la etapa del "modelo agroexportador". Fueron ańos en los que se profundizó la dependencia económica en relación al mercado mundial, y se estructuró una organización económica que respondía a los intereses y requerimientos de las naciones desarrolladas.

\section{Evolución y características del empleo en Catamarca y Tucumán (1880-1930)}

El "modelo agroexportador" profundizó la distancia entre la situación económica de la región Pampeana con la del interior del país. Las provincias pampeanas, y sobre todo Buenos Aires, fueron las que más beneficios obtuvieron de las transformaciones productivas del período. Por el contrario, el NOA fue una de las regiones que quedaron rezadas. La dinámica comercial que lo había caracterizado décadas atrás era definitivamente parte del pasado, y muchas de sus actividades productivas no lograron prosperar (véase Rofman et al., 1997; Rapoport, 2000; Ferrer, 2008).

En el Noroeste Argentino, Catamarca y Tucumán experimentaron procesos socioeconómicos muy distintos: mientras que la primera fue afectada por el estancamiento y decadencia de varias de sus producciones, conservando una participación muy reducida en la estrucutura económica nacional (Osatinsky, 2013b), Tucumán, sin poseer producción exportable, se insertó en la nueva dinámica económica del país a través de la creciente producción azucarera. Estas dinámicas disímiles, tuvieron su impacto en el plano demográfico y en el mercado de trabajo.

Mientras que Tucumán triplicó su población entre fines del siglo XIX y los primeros años del XX, Catamarca no logró siquiera duplicar la suya. Por ello la disminución en el peso relativo de cada provincia en la población nacional fue mayor en Catamarca, como se refleja en la tabla 1 .

Tabla 1. Población de Catamarca, Tucumán y la Argentina. 1869, 1895 y 1914

\begin{tabular}{|l|c|c|c|c|c|c|}
\hline & \multicolumn{2}{|c|}{$\mathbf{1 8 6 9}$} & \multicolumn{2}{c|}{$\mathbf{1 8 9 5}$} & \multicolumn{2}{c|}{$\mathbf{1 9 1 4}$} \\
\hline & Hab. & \% & Hab. & \% & Hab. & \% \\
\hline Catamarca & 79.962 & 4,6 & 90.161 & 2,3 & 100.769 & 1,3 \\
\hline Tucumán & 108.953 & 6,3 & 215.742 & 5,5 & 332.933 & 4,2 \\
\hline Total País & 1.737 .000 & 100 & 3.955 .110 & 100 & 7.885 .237 & 100 \\
\hline
\end{tabular}

Fuente: Censo Segundo Censo de la República Argentina, Tomo III, 1898; Tercer Censo Nacional Levantado $1^{\circ}$ de junio 1914, Tomo I, 1916.

La dinámica demográfica descripta estuvo ligada al mayor desarrollo que tuvo el mrecado de trabajo en Tucumán durante el período bajo estudio. La mayor demanda laboral hizo crecer el número de habitantes de esta provincia, lo que a su vez se tradujo en una 
Cuadernos de Trabajo /segunda época /número 5/ Ariel Osatinsky / Pobla-[...] 115 mayor población ocupada. En efecto, en 1895 Tucumán y Catamarca poseían 131.792 y 53.369 ocupados respectivamente. Para 1914 esta brecha se amplió. Por entonces, mientras que la población tucumana triplicaba a la de Catamarca, la población ocupada de Tucumán era cuatro veces mayor a la de su vecina provincia (207.615 y 57.867 ocupados respectivamente) ${ }^{5}$.

En cuanto a la distribución de la población ocupada en las distintas actividades económicas (Tabla 2), en Catamarca era mayor el peso de los ocupados en producciones primarias, mientras que en Tucumán, tenía mayor importancia el empleo en la actividad comercial. En relación a la industria, parecía tener el mismo peso en los ocupados de ambas provincias, aunque se trataba solo de los profesionales ocupados en la actividad. En Tucumán el sector manufacturero tenía mayor dimensión, reflejado ello en la importante participación de los ocupados sin trabajo fijo o profesión, fenómeno que se vinculaba a la creciente demanda laboral de los ingenios. Por su parte, en Catamarca sobresalía el empleo en manufacturas artesanales.

Tabla 2. Población ocupada según profesión en actividades económicas. Catamarca y Tucumán. 1895 y 1914

\begin{tabular}{|l|c|c|c|c|}
\hline Actividades Económicas & \multicolumn{2}{|c|}{$\mathbf{1 8 9 5}$} & \multicolumn{2}{c|}{$\mathbf{1 9 1 4}$} \\
\hline & Cat. & Tuc. & Cat. & Tuc. \\
\hline Agricultura y ganadería & 27,7 & 18,1 & 23,5 & 13,1 \\
\hline Producciones industriales & 21,9 & 15,1 & 22,5 & 21,2 \\
\hline Comercio & 2,1 & 3,9 & 3,0 & 4,3 \\
\hline Personal de servicio & 9,0 & 10,5 & 3,4 & 3,6 \\
\hline Adm Pública & 0,4 & 0,4 & 0,7 & 0,5 \\
\hline Instrucción y Educación & 0,6 & 0,4 & 3,0 & 1,2 \\
\hline Personal de fatiga sin trabajo fijo & 7,6 & 19,5 & - & - \\
\hline Sin profesiones & 28,2 & 30,0 & 41,8 & 53,8 \\
\hline TOTAL & $\mathbf{1 0 0}$ & $\mathbf{1 0 0}$ & $\mathbf{1 0 0}$ & $\mathbf{1 0 0}$ \\
\hline
\end{tabular}

Fuente: 1895: Segundo Censo de la República Argentina, Tomo III. Censos Complementarios, Buenos Aires, 1898. 1914: Tercer Censo Nacional Levantado $1^{\circ}$ de junio 1914, Tomo IV, Buenos Aires, 1916.

Estas realidades laborales disímiles, como se señaló, fueron consecuencia del desarrollo que tuvo la industria azucarera en Tucumán, que en aquellos años requería de un número importante y creciente de trabajadores ${ }^{6}$. Así, en 1914 el personal ocupado en las explotaciones agropecuarias (EAPs) tucumanas llegaba a 130.413 personas, mientras que

5 Datos de: Censo Segundo Censo de la República Argentina, Tomo III, 1898; Tercer Censo Nacional Levantado $1^{\circ}$ de junio 1914, Tomo I, 1916.

6 Mientras que en 1857 los peones y sirvientes conchabados en Tucumán eran 1.804, en 1880 estos ya ascendían a 10.590, para nuevamente crecer hasta ser 40.650 en 1890 (Campi, 1991, p. 183, citado por Bolsi et al., 1997, p. 115). 


\section{6/ Perspectivas Metodológicas /20/Vol. II /noviembre, Año 2017}

dicho valor para Catamarca se reducía a 52.384 trabajadores ${ }^{7}$. Habitantes de las provincias vecinas migraban hacia Tucumán en pos de trabajar en la zafra tucumana, ya sea en las explotaciones de los ingenios o en tierras de cañeros ${ }^{8}$. Por aquellos años, el desarrollo de la economía azucarera, y de otras producciones agropecuarias menores, no significó para los trabajadores la posibilidad de alcanzar condiciones de vida dignas. Por el contrario, estos soportaban pésimas condiciones de trabajo y jornadas laborales extenuantes ${ }^{9}$, no percibían salarios mínimos ni contaban con leyes protectoras (Santillán de Andres, 1969, p. 7), recibiendo incluso en muchos casos pagos no en dinero, sino en especies.

En la década de 1920 se sancionaron diversas leyes que buscaban mejorar las condiciones de trabajo en la producción azucarera ${ }^{10}$, las que en su mayoría entraron en vigencia con posterioridad a 1930, y que en muchos casos no fueron respetadas.

Mientras en Tucumán el mercado de trabajo se expandía, en Catamarca la demanda de empleo no alcanzaba a retener a su población. Por ello, "de los departamentos del oeste catamarqueño, y en menor medida del resto de la provincia, la población agrícola masculina comenzó a emigrar en forma estacional o permanente..." (Balán, 1976, p. 230), teniendo como destino en su mayoría la zafra azucarera tucumana. Esta migración era importante, estimada por Alfredo Palacios en alrededor de 8.000 trabajadores (más de la tercera parte de los obreros catamarqueńos) (Palacios, 1944).

La emigración no sólo tenía lugar por falta de empleo, sino que en muchas ocasiones trabajadores con ocupación en Catamarca buscaban emplearse en la zafra azucarera por las posibilidades que brindaba esta de obtener mayores ingresos. Esto por un lado implicaba una reducción de fuerza de trabajo empleada en actividades agrícolas o ganaderas de Catamarca, y por el otro reflejaba el mayor deterioro laboral que sufría por entonces la población catamarqueña. Sobre las condiciones salariales de los trabajadores de Catamarca a comienzos del siglo XX, Palacios señalaba:

Los obreros rurales $[\ldots]$ perciben un salario de ochenta centavos a un peso por día, trabajando largas jornadas. Es decir, una entrada mensual que en el mejor de los casos no pasa de treinta pesos. [...] El obrero urbano no gana más de dos pesos diarios, o sea sesenta pesos mensuales, y dos con cincuenta cuando es obrero del Estado, o sea sesenta y cinco pesos, por

7 Tercer Censo Nacional, Tomo V.1919.

8 Más de 10.000 ocupados transitorios participaban en cada zafra tucumana.

9 “...los operarios de los ingenios trabajaban 12 horas diarias con intervalos de media hora para almorzar. Los turnos corrían de 5 a 17 horas y de 17 a 5" (D. F. Salvatierra, citado por Santamaría, 1985, p. 168).

10 "La ley 1348 de 1923 estableció -en medio de la anunciada resistencia industrial- el salario mínimo. [...] Los obreros mayores de 18 años recibirían en virtud de esa ley 4,20 pesos como mínimo por jornada legal. Los peones a destajo ganarían el salario convenido con sus patronos [...] los pagos "deberán hacerse en moneda nacional de curso legal", con lo que quedaban legalmente eliminados el vale y la moneda falsa" (Ostengo de Ahumada, citado por Santamaría, 1985, p. 169).

La Ley 1346 de marzo de 1923 estableció las "ocho horas diarias o 48 semanales. [...] El 30 de septiembre de 1924 se sancionó la ley nacional 11317 sobre trabajo de mujeres y menores: quedaba prohibido el empleo de menores de 12 años y los menores de 14 no podrían trabajar en adelante ni en el servicio doméstico ni en empresas industriales o comerciales. Las mujeres mayores de 18 años no se ocuparían más de 8 horas diarias o 48 semanales y las menores de esa edad durante seis horas o 36 semanales. También se prohibía para ambas categorías el trabajo nocturno [...] El descanso del mediodía quedaba fijado en dos horas." (Santamaría, 1985, p. 170). 
veintiséis días. Y el costo de la vida de un obrero urbano no baja de ciento cincuenta pesos mensuales. (Palacios, 1944, pp. 111-112)

En la zafra azucarera de Tucumán, los jornales de los trabajadores en general oscilaban entre 1,50 y 2,50 pesos diarios (Palacios, 1938) lo que tampoco podía calificarse como un sueldo digno, aunque era un monto superior al percibido por gran parte de la población ocupada de Catamarca.

Los sueldos que percibían la mayoría de los trabajadores de Tucumán y Catamarca ${ }^{11}$, ya sea que trabajasen en la industria azucarera o en otras actividades, no les permitía alcanzar un nivel de vida satisfactorio. La Tabla 1 del Anexo muestra, en relación al material de las viviendas, que ambas provincias se encontraban en peor situación respecto del promedio del país. Tucumán tenía menos casas de paja que Catamarca, probablemente debido a su mayor urbanización ${ }^{12}$, lo que sugiere una menor precariedad en materia de infraestructura habitacional. Lo cierto es que un porcentaje mayoritario de las poblaciones de Tucumán y Catamarca no contaba por entonces con viviendas dignas.

En el plano educativo, ambas provincias tenían niveles de analfabetismo superiores al promedio que tenía la Argentina (Tabla 3). En 1914, todavía la mitad de la población en edad escolar se encontraba afectada por el analfabetismo en ambas provincias, siendo Catamarca la que mostraba una situación un poco mejor que la de Tucumán. En cuanto a la tasa de mortalidad infantil, también era Catamarca la que poseía menores niveles.

Tabla 3. Analfabetismo, mortalidad y mortalidad infantil en Catamarca, Tucumán y la Argentina

\begin{tabular}{|l|l|l|l|l|l|l|l|l|}
\hline & \multicolumn{2}{|l|}{ Analfabetismo* } & \multicolumn{6}{|c|}{ Tasa de Mortalidad Infantil } \\
\hline & $\mathbf{1 8 6 9}$ & $\mathbf{1 9 1 4}$ & \multicolumn{2}{|c|}{$\mathbf{1 9 1 4}$} & \multicolumn{2}{c|}{$\mathbf{1 9 3 6}$} & \multicolumn{2}{c|}{$\mathbf{1 9 4 7}$} \\
\hline & & & V & M & V & M & V & M \\
\hline Catamarca & 86,8 & 50,6 & 195,5 & 172 & 98,5 & 80 & 129,2 & 104,8 \\
\hline Tucumán & 88,4 & 52,3 & 223,5 & 218,4 & $181,67^{* * *}$ & 120,3 & 109,9 \\
\hline Argentina & 77,4 & 35,9 & 155,8 & 140,2 & & & 92,9 & 79,3 \\
\hline
\end{tabular}

Fuente: * Dirección Nacional de Estadística y Censos (1956), Informe demográfico de la República Argentina 1944-1954, Buenos Aires. ${ }^{* *}$ IV Censo General de la Nación Tomo I, Censo de Población 1947, Buenos Aires. ${ }^{* * *}$ Boletín Estadístico No 12 Tucumán 1955. Corresponde al año 1935.

Siendo el último de los indicadores mencionados el de mayor relevancia, podemos concluir que en el período analizado Catamarca tenía una situación social menos crítica que la de Tucumán, aunque en ambas las condiciones de vida eran insatisfactorias y

11 Un ejemplo de los mayores sueldos de Tucumán en comparación con Catamarca lo brindaba una planilla de empleados civiles de ambas provincias de 1914. La misma informaba que en Catamarca el $30 \%$ de estos percibía un sueldo de entre 31 y $40 \$ \mathrm{~m} / \mathrm{n}$, mientras que otro $42 \%$ se situaba entre 41 y $60 \$ \mathrm{~m} / \mathrm{n}$. En Tucumán, por el contrario, el 17\% recibía sueldos de entre 41 a $60 \$ \mathrm{~m} / \mathrm{n}$, el $61 \%$ cobraba un monto situado entre 61 y $100 \$ \mathrm{~m} / \mathrm{n}$ (Bunge, 1917, p. 136-137).

12 Tucumán poseía un mayor porcentaje de población urbana. En 1914 esta provincia concentraba ya el $42,6 \%$ de su población en zona urbana, mientras que para Catamarca dicho valor era 31,2\% (Bolsi, 2000). 


\section{8/ Perspectivas Metodológicas /20/Vol. II /noviembre, Año 2017}

estaban alejadas del promedio nacional. Las transformaciones productivas que "modernizaron" la economía de Tucumán generaron una mayor demanda de fuerza de trabajo en relación al mercado de trabajo catamarqueño. Pese a ello, las condiciones de vida de su población no eran hasta 1930 mejores que las que caracterizaban a Catamarca.

A partir de 1930, la Argentina transitará un proceso de transformación en su economía, la etapa conocida como industrialización sustitutiva de importaciones, que se extendería hasta los años 70 , y provocaría modificaciones socioeconómicas de relevancia en las distintas provincias del país.

\section{Primera etapa de la industrialización sustitutiva de importaciones (1930-1955)}

No es propósito de este artículo realizar un análisis de los cambios económicos que se produjeron en el marco del denominado proceso de industrialización sustitutiva de importaciones (ISI), pero si es importante señalar algunas características de la etapa, por el impacto que tuvieron en el mercado de trabajo. En ese sentido, cabe destacar que la composición de la estrucutura productiva tuvo alteraciones, con sector manufacturero que adquirió mayor peso ${ }^{13}$, mientras que el sector agropecuario perdió relevancia ${ }^{14}$, aunque seguiría siendo importante al seguir constituyendo el origen de las exportaciones del país. Por su parte, la mayor urbanización, la infraestructura que requirió la industria, y la intervención del Estado en la economía hicieron crecer notablemente el peso de las actividades del sector terciario (Rofman et al., 1997; Rapoport 2000, Ferrer, 2008).

El desarrollo industrial, si bien comenzó de manera incipiente en la década de 1930, se aceleró a partir de los años 40, proceso en el que influyó la ampliación del mercado interno y el mayor poder adquisitivo que tendría la población por esos años (Rapoport, 2000).

En la primera fase de la ISI, las economías de Catamarca y Tucumán tuvieron dinámicas distintas. En el sector primario, Catamarca experimentó una caída en el número de EAPs entre 1937 y 1947, mientras que estas aumentaron en Tucumán ${ }^{15}$. A su vez, la superficie cultivada continuaba siendo muy superior en Tucumán: mientras que Catamarca poseía 52.989 hectáreas cultivadas en 1947, cifra inferior a la que tenía en 1914, Tucumán poseía bajo cultivo 298.635 hectáreas, habiéndose incrementado en más de 100.000 hectáreas en relación al total que poseía en $1914^{16}$. Estas diferencias se explicaban por el desarrollo que continuó teniendo en tierras tucumanas el cultivo de caña de azúcar.

En el plano industrial, si bien aumentó el número de establecimientos, la brecha entre la cantidad existente en ambas provincias se fue ampliando. En 1935, Tucumán

13 Este proceso de industrialización tuvo limitaciones importantes. Se trataba de un crecimiento de la industria que no había sido planificado por el gobierno, sino que tuvo lugar como consecuencia de la coyuntura que atravesaba el país. A su vez, estuvo concentrado sobre todo en las industrias livianas.

14 Tomado de conjunto, el sector agropecuario disminuyó su producción en un 10\% entre 1935-1939 y 1950-1954 (Peláez, 1998, p. 183).

15 En 1937 Tucumán tenía 14.310 explotaciones agropecuarias y Catamarca poseía 7.002 (Censo Nacional Agropecuario 1937). En 1947 estas provincias tenían 16.645 y 4.733 EAPs respectivamente (IV Censo General de la Nación. Tomo II, 1952).

16 En 1914 Tucumán y Catamarca tenían 179.483 y 76.372 hectáreas cultivadas respectivamente (Tercer Censo Nacional, Tomo V, 1919). 
Cuadernos de Trabajo /segunda época /número 5/ Ariel Osatinsky / Pobla-[...] 119 tenía una cantidad de establecimientos tres veces superior que Catamarca, mientras que en 1946 y 1954 esa distancia era mayor ${ }^{17}$.

El sector comercial también era de mayor dimensión en Tucumán, contando esta con 5.736 establecimientos en 1946, mientras que Catamarca tenía por entonces $1.531^{18}$.

La tabla 4 muestra la composición que tenían las estructuras productivas de ambas provincias en 1953.

En Tucumán las actividades agropecuarias y manufactureras tenían un peso destacado, explicando más del 50\% de la economía provincial. Por el contrario, en Catamarca eran las actividades vinculadas al gobierno las que sobresalían, como ser construcción (obras públicas) y servicios gubernamentales, teniendo también las actividades agropecuarias una importante participación en la estructura productiva provincial.

Tabla 4. Producto Bruto Interno 1953. Catamarca y Tucumán (Composición porcentual (\%))

\begin{tabular}{|l|c|c|}
\hline Grandes divisiones & Catamarca & Tucumán \\
\hline Agricult., ganad., y pesca & 18,8 & 29,6 \\
\hline Minería & 0,6 & - \\
\hline Industria & 8,4 & 23,3 \\
\hline Construcción & 16,4 & 4 \\
\hline Servic. No Gubernam. & 33,8 & 34 \\
\hline Gobierno & 22 & 9,1 \\
\hline Total & $\mathbf{1 0 0}$ & $\mathbf{1 0 0}$ \\
\hline
\end{tabular}

Fuente: CFI - Instituto Torcuato Di Tella, Relevamiento de la estructura regional de la economía argentina, Buenos Aires, 1963, vol. II. Citado por Rofman et. al., 1997, p. 193.

Las diferencias existentes en las dinámicas de los principales sectores económicos de ambas provincias se explican, sobre todo, por la expansión de la agroindustria azucarera en Tucumán. Este desarrollo, que continuó en las décadas de 1930, 1940 y $1950^{19}$, se tradujo en un crecimiento de la superficie cultivada, del sector manufacturero, y de la actividad comercial, teniendo en cuenta que la producción azucarera posee un importante encadenamiento con un conjunto de actividades económicas desde su fase primaria hasta la comercial. (Osatinsky, 2012a)

17 Catamarca y Tucumán contaban con 233 y 694 establecimientos industriales en 1935. Diez años después, esos valores ascendían a 352 y 1.409 respectivamente. En 1954 Tucumán contaba con 2.550 establecimientos, mientras que Catamarca poseía 645 (Datos de Censo Nacional Económico. 1935, 1946 y 1954).

18 Datos IV Censo General de la Nación Tomo III, 1952.

19 La producción de azúcar era una actividad que contaba hacia 1940 con 28 ingenios distribuidos en diferentes localidades de la provincia. Los cañeros, que en 1930 eran 6.072, crecieron hasta llegar a ser 19.347 en 1945. Fueron décadas en las que se produjo una importante expansión de la superficie cultivada con caña y de la producción de azúcar (véase Osatinsky, 2012). 
Población y mercado de trabajo en Catamarca y Tucumán (1930-1955)

La importante distancia que había entre la cantidad de habitantes de Catamarca y Tucumán se mantuvo como una constante durante la primera etapa de la ISI (Tabla 5).

Tabla 5. Población en Catamarca, Tucumán y la Argentina. 1914, 1947 y 1960

\begin{tabular}{|l|c|c|c|c|c|c|}
\hline & \multicolumn{2}{|c|}{1914} & \multicolumn{2}{c|}{$\mathbf{1 9 4 7}$} & \multicolumn{2}{c|}{$\mathbf{1 9 6 0}$} \\
\hline & No & \%/país & No & \%/país & No & \%/país \\
\hline Catamarca & 100.769 & 1,3 & 147.213 & 0,9 & 168.231 & 0,8 \\
\hline Tucumán & 332.933 & 4,2 & 593.371 & 3,7 & 773.972 & 3,9 \\
\hline Total País & 7.885 .237 & 100 & 15.893 .827 & 100 & 20.010 .539 & 100 \\
\hline
\end{tabular}

Fuente: Tercer Censo Nacional (1916); IV Censo General de la Nación (1952); Censo Nacional de Población 1960.

Tucumán tuvo un mayor crecimiento demográfico. Por ello, si bien ambas provincias redujeron su peso relativo en la población total del país, esa disminución fue mayor en Catamarca. Importa señalar también que fueron años en los que el proceso emigratorio tuvo continuidad, más agravado en Catamarca ${ }^{20}$. La emigración reflejaba la existencia de una estructura productiva que no lograba contener a las poblaciones de cada provincia, situación que ocasionó la búsqueda de nuevas fuentes de empleo, ya sea en las ciudades del mismo territorio provincial, o migrando a Buenos Aires u otras regiones del país en donde, como consecuencia de la industrialización sustitutiva de importaciones, surgieron nuevas actividades. La mayor emigración catamarqueña era un indicador del profundo deterioro laboral que afectaba a la población de la provincia.

El hecho de que la población tucumana fuese a mediados del siglo XX cuatro veces mayor que la de Catamarca explicaba la mayor cantidad de población ocupada que había en Tucumán. Mientras que esta tenía 198.156 ocupados en 1946, ese valor se reducía a 47.998 en Catamarca ${ }^{21}$.

Como se observa en la Tabla 6, el $40 \%$ de los ocupados catamarqueños lo estaba en el sector primario, y un $17 \%$ eran empleados estatales, siendo en Tucumán esos valores $30 \%$ y $8 \%$ respectivamente. En esta última, el 30\% se ocupaba en el sector industrial, diez puntos más que en Catamarca. En el sector terciario, el comercio y transporte ocupaban el $11 \%$ y el $6 \%$ de los ocupados tucumanos, mientras que en Catamarca estos valores eran $7 \%$ y $3 \%$.

Tabla 6. Población ocupada según actividad económica. Catamarca y Tucumán 1946

\begin{tabular}{|l|c|c|}
\hline & Catamarca & Tucumán \\
\hline Producción Básica & $\mathbf{3 9 , 1}$ & $\mathbf{2 9 , 8}$ \\
\hline Agropecuaria & 33,1 & 27,4 \\
\hline Producción secundaria & $\mathbf{2 0 , 9}$ & $\mathbf{3 0 , 6}$ \\
\hline Alimentación & 1,0 & 15,9 \\
\hline
\end{tabular}

20 la tasa de migración neta intercensal para el período 1947/60 fue de -60,21 por mil y -164,36 por mil para Tucumán y Catamarca (Ortiz D’Arterio, 1997).

21 Datos de Anuario Estadístico de la República Argentina. Tomo I, Compendio 1948, 1951. 
Cuadernos de Trabajo /segunda época /número 5/ Ariel Osatinsky / Pobla-[...] 121

\begin{tabular}{|l|c|c|}
\hline Textiles & 10,4 & 0,2 \\
\hline Construcción & 3,4 & 4,4 \\
\hline Electric., gas y agua & 0,3 & 0,2 \\
\hline Servicios & & \\
\hline Comercio, bancos, oficinas y seguros & $\mathbf{3 6 , 9}$ & $\mathbf{3 6 , 8}$ \\
\hline Transportes Terrestres & 6,6 & 11,2 \\
\hline Actividades de los Estados Nac., Prov., Municip. & 3,1 & 6,0 \\
\hline Otros servicios & 16,7 & 8,4 \\
\hline serv doméstico & 3,0 & 4,2 \\
\hline Desconocidas & 7,5 & 7,0 \\
\hline Total & 3,1 & 2,8 \\
\hline
\end{tabular}

Fuente: Anuario Estadístico de la República Argentina. Tomo I, Compendio 1948, 1951

Los censos Económicos también muestran una diferencia importante entre ambas provincias en los ocupados en los sectores industria y comercio, siendo la población ocupada mucho mayor en Tucumán (Tabla 7).

Tabla 7. Ocupados en industria y comercio en Catamarca y Tucumán 1935, 1946 у 1954

\begin{tabular}{|c|c|c|c|c|c|c|c|}
\hline \multicolumn{9}{|c|}{ Industria manufacturera } & \multicolumn{2}{c|}{ Comercio } \\
\hline \multicolumn{2}{|c|}{$\mathbf{1 9 3 5}$} & \multicolumn{2}{|c|}{$\mathbf{1 9 4 6}$} & \multicolumn{2}{c|}{$\mathbf{1 9 5 4}$} & \multicolumn{2}{c|}{1946} \\
\hline Cat. & Tuc. & Cat. & Tuc. & Cat. & Tuc. & Cat. & Tuc. \\
\hline 1.394 & 11.076 & 3.918 & 23.806 & 3.708 & 41.360 & 2.250 & 12.132 \\
\hline
\end{tabular}

Fuente: Censo Nacional Económico. 1935, 1946 y 1954

El hecho de que casi el $60 \%$ de la población ocupada catamarqueña trabajase en actividades primarias o en servicios del Estado era un síntoma del escaso desarrollo económico que tenía esa provincia por entonces. La Encuesta sobre Desocupación de los años 30 (1937) señalaba que las dificultades laborales que afectaban a la provincia estaban vinculadas con sus problemas económicos. En el oeste, la actividad ganadera había disminuido y ya no mostraba el dinamismo que había tenido décadas atrás. En el sur, la actividad agrícola no podía competir con los productos que provenían de otras regiones, siendo también afectadas por productos traídos de afuera las escasas producciones artesanales existentes como los tejidos.

En algunas zonas del interior provincial, la producción agrícola y ganadera para el propio consumo, atenuaba los efectos de la desocupación, pero esta crecía en la capital al calor de las migraciones de desocupados de zonas rurales ${ }^{22}$. El elevado porcentaje de ocupados en actividades gubernamentales que tenía Catamarca reflejaba ya lo que sería una constante: la fuerte presencia del empleo estatal como atenuante de la desocupación y los problemas de empleo.

22 Datos de la Encuesta sobre Desocupación de 1937, citados por Girbal-Blacha, 2003, pp. 41-42. 
Tucumán, por su parte, tenía una menor desocupación ${ }^{23}$ como consecuencia de su mayor desarrollo económico. Gran parte de su población activa estaba ocupada en distintas actividades vinculadas a la producción azucarera.

La mayoría de estos trabajadores tucumanos en los años 30, soportaban condiciones de trabajo precarias, por lo que sufrían problemas alimentarios, sanitarios (mortalidad infantil, mal de chagas, etc.), habitacionales (viviendas precarias), deserción escolar, analfabetismo, y salarios muy inferiores al costo de vida (Palacios, 1938, Osatinsky, 2001).

En la década de 1940, sobre todo con el peronismo, los trabajadores de la actividad azucarera lograron satisfacer varios de sus reclamos, obteniendo mejoras salariales y en las condiciones de trabajo ${ }^{24}$. Asimismo, creció el número de trabajadores en la industria azucarera $^{25}$. Sin embargo, hacia la primera mitad de la década de 1950, las concesiones en materia laboral se irían restringiendo a medida que aumentaban los problemas económicos que sufría el país, y las dificultades presupuestarias del Gobierno (Osatinsky, 2012a).

En materia de ingreso, el sueldo medio de la población ocupada en la industria tucumana entre 1935 y 1954 era superior al promedio del país, siendo en Catamarca la mitad de la media nacional (Tabla 8). Incluso entre 1946 y 1954, dicho salario promedio se incrementó en Tucumán, probablemente debido a los aumentos salariales que obtuvieron los trabajadores en la etapa peronista, mientras que en el caso catamarqueño este se redujo.

Tabla 8. Sueldo promedio de población ocupada en sector industrial, Catamarca, Tucumán y la Argentina, 1935, 1946 y 1954 (en números índices)

\begin{tabular}{|c|c|c|c|}
\hline & $\mathbf{1 9 3 5}$ & $\mathbf{1 9 4 6}$ & $\mathbf{1 9 5 4}$ \\
\hline Catamarca & 50 & 77 & 54 \\
\hline Tucumán & 123 & 106 & 126 \\
\hline Total País & 100 & 100 & 100 \\
\hline
\end{tabular}

Fuente: Rofman et al., 1997, pp. 199-200, sobre la base de datos de los Censos Industriales

De los distintos aspectos señalados del mercado de trabajo, se percibe que Catamarca tuvo una situación laboral más crítica que su vecina provincia, en donde la producción azucarera explicaba gran parte de los procesos laborales.

En cuanto a la situación social, en ambas provincias un número importante de habi-

23 El primer cesno nacional de desocupados realizado en 1932 señalaba la existencia de 2.717 y 3.180 desocupados en Catamarca y Tucumán, respectivamente (Panettieri, 1997). Si se tiene en cuenta que Tucumán tenía una población y población activa mucho mayor a la de Catamarca, se entiende que esta última estaba más afectada por el desempleo.

24 Los trabajadores azucareros obtuvieron en aquellos años salario mínimo, salario familiar, salario complementario anual, atención médica gratuita, vacaciones pagas, vivienda adecuada, leche para los hijos menores y educación para los niños, facilidades para la alimentación, días festivos nacionales, etc. Para ello, fue clave el surgimiento de la Federación Obrera Tucumana de la Industria Azucarera (FOTIA) en el año 44 la que, agrupando a todos los sindicatos de los ingenios de la provincia y de los obreros del surco, logró imprimirle a las huelgas y conflictos un carácter masivo (Rubinstein, 2006, citado en Osatinsky, 2012a).

25 La industria azucarera agrupaba en 1943 a 21.713 trabajadores, mientras que en 1947 la cantidad era ya de 30.000 (Rubinstein, 2006: 126, citado en Osatinsky, 2012a). 
tantes no tenía acceso a un nivel de vida digno ${ }^{26}$ en los años 30 , produciéndose durante los ańos del peronismo, una mejora relativa.

Al igual que en el período del modelo agroexportador, para el lapso de 1930-1955 no se cuentan con mediciones de pobreza. Por ello, nuevamente se tuvo en cuenta la tasa de analfabetismo y, sobre todo, la mortalidad infantil como indicadores de las condiciones de vida de la población ${ }^{27}$.

Respecto al primero de ellos, Catamarca en 1947 seguía teniendo una mejor situación que Tucumán (Tabla 9).

Tabla 9. Tasa de analfabetismo. Catamarca y Tucumán. 1947, 1960, 1970

\begin{tabular}{|l|c|c|c|}
\hline & $\mathbf{1 9 4 7}^{*}$ & $\mathbf{1 9 6 0}^{* *}$ & $\mathbf{1 9 7 0}^{* *}$ \\
\hline Catamarca & 18,2 & 11,6 & 9,5 \\
\hline Tucumán & 21,1 & 13 & 12,7 \\
\hline
\end{tabular}

Fuente: * Dirección Nacional de Estadística y Censos, (1956); ${ }^{* *}$ Censo Nacional de Población, 1960 y 1970.

En cuanto a la mortalidad infantil, a diferencia de lo que ocurría antes de 1930, era Tucumán la que tuvo en el período analizado una situación menos crítica. En efecto, esta se redujo en ambas provincias entre 1944 y 1948, y a partir de ese ańo, y hasta 1955 la mortalidad infantil tuvo una tendencia creciente en Catamarca, mientras que en Tucumán continuó disminuyendo (Gráficos 1 y 2) ${ }^{28}$.

26 Alfredo Palacios en un viaje realizado al norte del país en la década de 1930, en referencia a Catamarca afirmaba: "Considera el doctor Olaran que la gran miseria de la población es la causante principal de la elevada morbi-mortalidad, pues la falta de alimentación, de ropas y de viviendas reviste caracteres alarmantes" (Palacios, 1938, p. 152). Respecto de Tucumán decía: "Las viviendas de los suburbios son peor aún que las de Santiago del Estero. Hechas de quincha, paja, adobe y lona destrozadas, miden, generalmente, tres metros por cuatro. El piso es la tierra: en su interior, catres sucios y maltrechos, o harapos tirados en el suelo y unos cuantos cajones que reemplazan las sillas." (Palacios, 1938, p. 84). "La provincia de Tucumán es muy rica y tiene hoy 27 ingenios azucareros, que actualmente trabajan día y noche, pero el pueblo es muy pobre y sufre hambre" (Palacios, 1938, p. 95).

27 No se pudo encontrar indicadores relacionados con la calidad de las viviendas que había en las diferentes provincias argentinas para el período 1930-1955.

28 En el Gráfico 2, la sobremortalidad infantil Tucumán/Catamarca es el resultado del cociente entre la mortalidad infantil de Tucumán y de Catamarca multiplicado por cien. 


\section{Gráfico 1. Mortalidad infantil en Catamarca y Tucumán. 1946-1980}

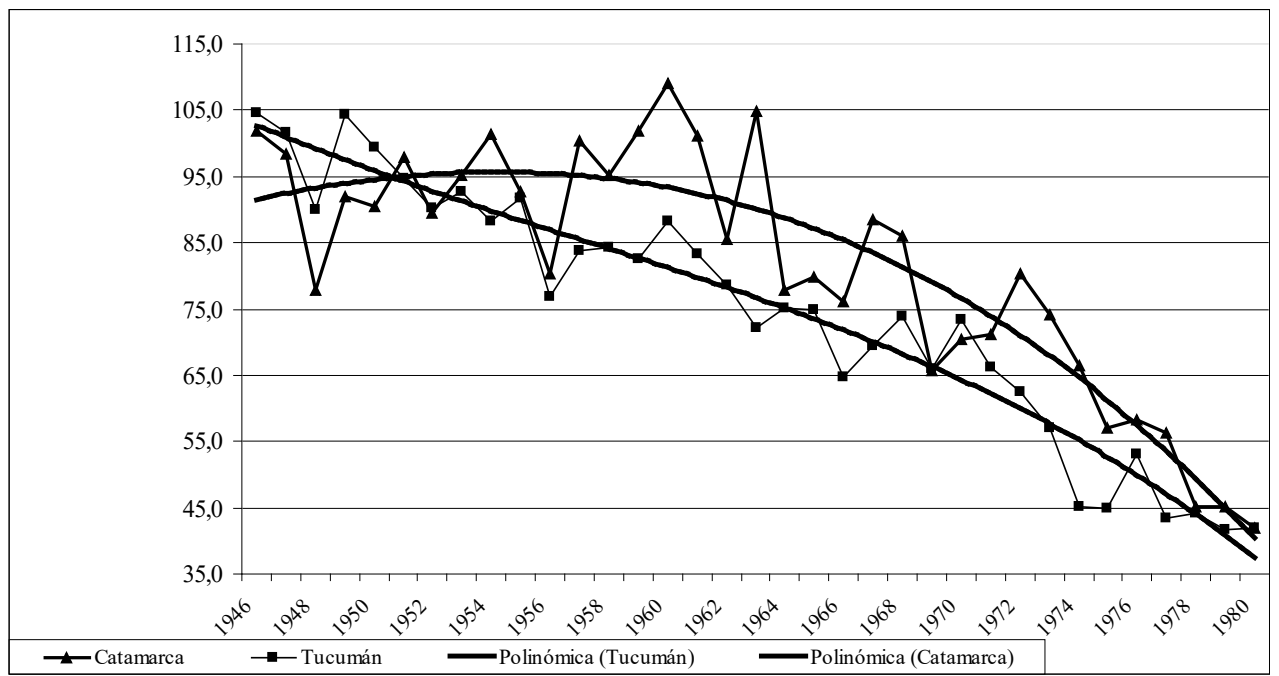

Fuente: Elaboración propia sobre la base datos de: Dirección Nacional de Estadísticas y Censos (1956), Informe demográfico de la República Argentina 1944-1954, Buenos Aires; Dirección Nacional de Estadística y Censos, Hechos demográficos en la República Argentina 1954-1960; INDEC, Hechos demográficos en la República Argentina 1961-1966, Tomo I; Dirección de Estadísticas y Censos de Catamarca, Anuario Estadístico de la Provincia de Catamarca 19601980; Bolsi y Ortiz de D'Arterio (2001), Población y Azúcar en el Noroeste Argentino. Mortalidad infantily transición demográfica durante el siglo XX, Ed. Instituto de Estudios Geográficos (UNT), San Miguel de Tucumán.

\section{Gráfico 2. Sobremortalidad infantil Tucumán/Catamarca. 1946-1980}

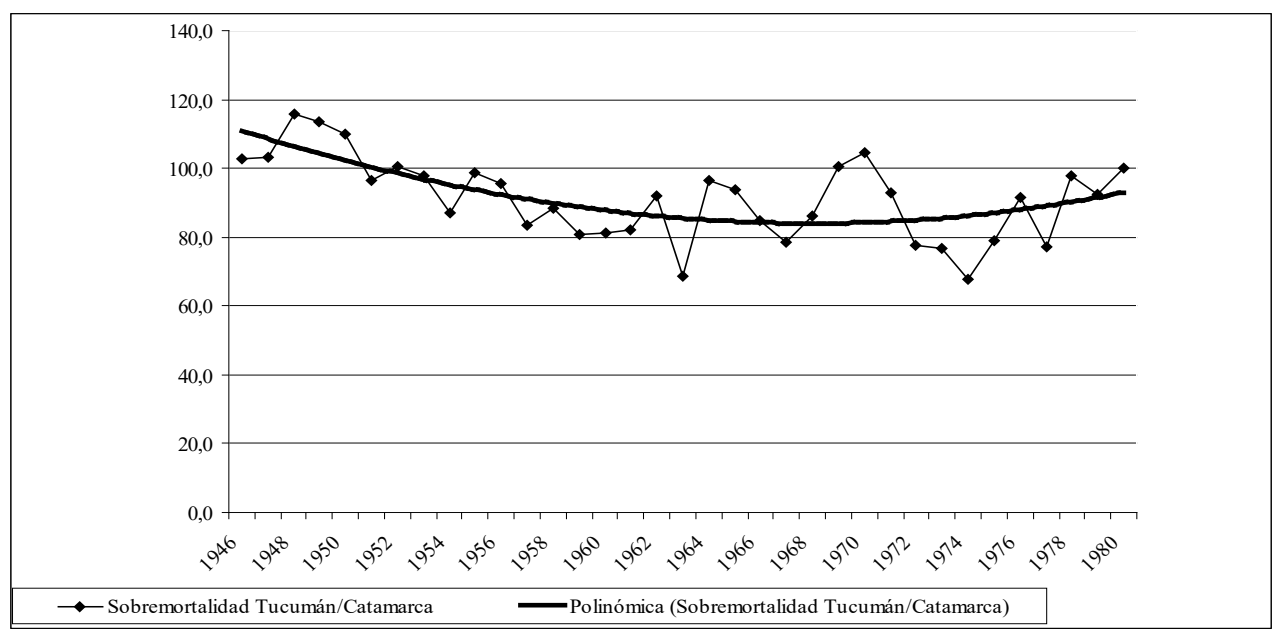

Fuente: Elaboración propia sobre la base datos de: Dirección Nacional de Estadísticas y Censos (1956), Informe demográfico de la República Argentina 1944-1954, Buenos Aires; Dirección Nacional de Estadística y Censos, Hechos demográficos en la República Argentina 1954-1960; 
Cuadernos de Trabajo /segunda época /número 5/ Ariel Osatinsky / Pobla-[...] 125

INDEC, Hechos demográficos en la República Argentina 1961-1966, Tomo I; Dirección de Estadísticas y Censos de Catamarca, Anuario Estadístico de la Provincia de Catamarca 19601980; Bolsi y Ortiz de D’Arterio (2001), Población y Azúcar en el Noroeste Argentino. Mortalidad infantily transición demográfica durante el siglo XX, Ed. Instituto de Estudios Geográficos (UNT), San Miguel de Tucumán.

Debido a que la mortalidad infantil es más relevante como indicador de la realidad social, podemos afirmar que en el período la población catamarqueña sufrió una situación social más crítica que la tucumana.

La mejor situación socioeconómica de Tucumán, era en gran medida producto de la importante presencia de la actividad azucarera. Al mismo tiempo, ello sería una pesada carga en el sentido de que el peso preponderante que tenía dicha actividad en la estructura productiva provincial, ataba la suerte de la economía de Tucumán a los vaivenes de la misma (Osatinsky, 2012a).

\section{5-1970: Transformaciones económicas regresivas}

La segunda etapa de la industrialización sustitutiva de importanciones, se caracterizó por políticas económicas que avanzaron en la concentración y transnacionalización de la producción. La búsqueda de una mayor modernización y la eficiencia del sector productivo ocasionó una mejora sustancial de los sectores más concentrados de la actividad económica, al tiempo que perjudicó a numerosas pequeñas y medianas empresas, y a gran cantidad de pequeńos y medianos productores (Rofman et al., 1997; Rapoport, 2000; Ferrer, 2008).

Fueron años en los que el sector manufacturero incrementó su peso en la estrucutura productiva, fruto de un proceso que, como se señaló, benefició a las grandes empresas. A su vez, fueron las actividades terciarias, como los servicios y el comercio, las que aumentaron su peso en la economía nacional, mientras que la actividad agropecuaria disminuyó aún más su participación en la estrucutrra productiva del país.

En este período la economía tucumana experimentó serias dificultades por los cambios regresivos que afectaron la actividad azucarera de la provincia. Esta, que tuvo un crecimiento importante en la primera mitad de la década de 1960, experimentó a partir de 1966, durante la dictadura de Onganía, el cierre de 11 de los 27 ingenios azucareros, la disminución de la superficie con caña y del número de explotaciones cañeras, y el descenso de la producción de azúcar, medidas que afectaron sobre todo a pequeños productores y a los trabajadores vinculados a esta agroindustria (Osatinsky, 2012a).

La crisis azucarera acentuó la disminución que los sectores agropecuario y manufacturero venían teniendo antes de 1966 en su participación en la estructura productiva tucumana (Tabla 10) ${ }^{29}$. En contraposición, la mayoría de las actividades del sector terciario incrementaron su participación dentro de la economía provincial.

29 La superficie con cultivos, superior a 300.000 hectáreas en 1960, tuvo un crecimiento en la década de solo $16 \%$, que se explica por la expansión de los cereales y oleaginosas, sufirendo la superficie con caña un importante descenso. 
126/ Perspectivas Metodológicas /20/Vol. II /noviembre, Año 2017

Tabla 10. Composición del Producto Bruto Geográfico de Tucumán y Catamarca entre 1953 y 1970 (\%, ańos seleccionados)

\begin{tabular}{|l|c|c|c|c|c|c|}
\hline \multicolumn{1}{|c|}{ Grandes divisiones } & \multicolumn{3}{c|}{ Tucumán } & \multicolumn{3}{c|}{ Catamarca } \\
\hline Agropecuario, etc. & $\mathbf{1 9 5 3}$ & $\mathbf{1 9 6 1}$ & $\mathbf{1 9 7 0}$ & $\mathbf{1 9 5 3}$ & $\mathbf{1 9 6 1}$ & $\mathbf{1 9 7 0}$ \\
\hline Minas y canteras & 30 & 25 & 22 & 19 & 13 & 16 \\
\hline Industria manufacturera & - & 0 & 0 & 1 & 2 & 6 \\
\hline Construcción & 4 & 16 & 14 & 8 & 8 & 5 \\
\hline Electricidad, gas, agua & $/$ & 2 & 2 & $/$ & 3 & 12 \\
\hline Transporte & $/$ & 16 & 9 & $/$ & 2 & 5 \\
\hline Comunicaciones & $/$ & 1 & 1 & $/$ & 2 & \\
\hline $\begin{array}{l}\text { Comercio, restaurantes y } \\
\text { hoteles }\end{array}$ & $/$ & 13 & 16 & $/$ & 9 & 15 \\
\hline $\begin{array}{l}\text { Establec. financieros, seguros, } \\
\text { bs. inmuebles y serv. a empresas }\end{array}$ & $/$ & 3 & 7 & $/$ & 7 & 5 \\
\hline Servicios & $43,1^{*}$ & 17 & 23 & $55,8^{*}$ & 47 & 35 \\
\hline Total & $\mathbf{1 0 0}$ & $\mathbf{1 0 0}$ & $\mathbf{1 0 0}$ & $\mathbf{1 0 0}$ & $\mathbf{1 0 0}$ & $\mathbf{1 0 0}$ \\
\hline
\end{tabular}

La fuente únicamente diferencia entre servicios no gubernamentales (34\% tanto en Tucumán como en Catmarca) y gobierno ( $9 \%$ en Tucumán, 22\% en Catamarca). El sector servicios incluye: administración pública y defensa; servicios sociales y comunales conexos; servicios de diversión y esparcimiento y servicios personales y de los hogares. Fuentes: 1953: CFI - Instituto Torcuato Di Tella, 1963. Tomado de Rofman et al., 1997 [1973]: 193; 1961-1970: Dirección de Estadística Tucumán, 1978.

La economía de Catamarca también sufrió transformaciones en el período ${ }^{30}$. Su sector agropecuario tuvo un incremento tanto en la producción ganadera, como en la superficie ocupada con cultivos, la cual sin embargo, continuó ocupando una porción muy reducida de la superficie total con explotaciones agropecuarias ${ }^{31}$. La industria mantuvo su nivel de atraso y reducida dimensión, conformada, en su mayoría, por establecimientos pequeños, que no generaban una demanda importante de mano de obra. Hacia 1963 el sector mostraba una notable disminución de los establecimientos respecto a la situación existente diez años atrás ${ }^{32}$. En 1970, la industria todavía mantenía sus niveles artesanales, teniendo una dimensión muy reducida en la provincia (Osatinsky, 2013b).

En el sector terciario, el comercio y los servicios privados tuvieron una expansión. En 1964 la cantidad de establecimientos duplicaba a la existente veinte años atrás ${ }^{33}$,

30 Para una análisis más extenso sobre las trasnformaciones económicas del período en Catamarca, véase Osatinsky, 2013b.

31 El número de cabezas de ganado se incrementó en Catamarca de 515.714 a 635.388 en 1960-69. En el mismo periodo, la superficie con cultivos pasó de 28.373 a 72.459 hectáreas (Datos del Censo Nacional Agropecuario, 1960 y 1969).

32 Los establecimientos manufactureros se redujeron de 645 a 417 en el período 1953-1963 (Censo nacional Económico, 1954 y 1964).

33 En 1946 y 1964 Catamarca contaba con 1.531 y 3.193 establecimientos respectivamente (Datos del Censo Nacional Económico 1964). 

creciendo con posterioridad, hasta llegar a ser 3.992 en $1974^{34}$. En la composición del PBG catamarqueño en este período (Tabla 10), hubo una importante caída de la participación de la industria, y una leve disminución del peso del sector agropecuario. A su vez, en el sector secundario, era la construcción la actividad que tenía mayor importancia, probablemente debido a las obras públicas realizadas por el gobierno. Por su parte, el sector que más importancia adquirió en la estructura provincial fue el que agrupaba los servicios del sector público.

En 1970 aproximadamente la mitad de su PBG era generado por la construcción o los servicios del sector público. Asimismo, los sectores agropecuario y manufacturero poseían en aquel año un peso relativo muy bajo ( $20 \%$ del PBG aproximadamente).

Las dificultades económicas que atravesaron Catamarca y Tucumán durante la segunda fase del proceso sustitutivo de importaciones impactaron de manera negativa en el plano demográfico de ambas provincias. En particular, Tucumán sufriría un mayor deterioro laboral, como consecuencia de la crisis de la actividad azucarera, lo cual desembocaría en una pronunciada emigración de la provincia.

\section{Población y problemas de empleo en Catamarca y Tucumán (1955-1970)}

La década de 1960 significó un retroceso en cuanto a la participación de Tucumán y Catamarca en la población total del país, como se observa en la tabla 11.

El deterioro demográfico fue mayor en el caso de Tucumán. En esta provincia, si se tiene presente que la población estimada para el ańo 1970 era de 932.431 personas, se puede afirmar que más de 160.000 tucumanos tuvieron que migrar debido principalmente al cierre de los ingenios. Catamarca sufrió una menor migración que Tucumán en términos absolutos, aunque tuvo un crecimiento demográfico muy reducido, por lo que también en el período 1960-70 la Tasa de Migración Neta Intercensal (TMNI) fue nuevamente mayor en esta provincia ${ }^{35}$, siendo, sin embargo, menor la distancia respecto de la de Tucumán en comparación con los períodos anteriores.

Tabla 11. Población en Catamarca, Tucumán y la Argentina. 1960 y 1970

\begin{tabular}{|c|c|c|c|c|c|}
\hline & \multicolumn{2}{|c|}{1960} & \multicolumn{2}{c|}{1970} & $\begin{array}{r}\text { Var. \% } \\
1960 / 70\end{array}$ \\
\hline & Habitantes & $\%$ & Habitantes & $\%$ & \\
\hline Catamarca & 168.231 & 0,8 & 172.323 & 0,7 & 2,4 \\
\hline Tucumán & 773.972 & 3,9 & 765.962 & 3,3 & $-1,0$ \\
\hline Total País & 20.010 .539 & 100 & 23.364 .070 & 100 & 16,8 \\
\hline
\end{tabular}

Fuente: Censo Nacional de Población y Viviendas 1960 y 1970.

Estas dinámicas demográficas tenían relación con los problemas de empleo que había en las provincias bajo estudio, como lo refleja el descenso que hubo en la población ocu-

34 Datos del Censo Nacional Económico 1974.

35 Mientras que en Tucumán la migración neta fue de 167.210 personas en la década de 1960, este valor en Catamarca fue de 63.554. Así, la TMNI para ambas provincias fue de -217 por mil y -373 por mil respectivamente (Ortiz de D’Arterio, 1997: 113). 


\section{8/ Perspectivas Metodológicas /20/Vol. II /noviembre, Año 2017}

pada en la industria manufacturera en el período 1953-1963 ${ }^{36}$. En el caso de Catamarca, el estancamiento y la reducida dimensión de su economía impedían una expansión notable de la demanda de mano de obra, lo que explicaba que la emigración continuase. En Tucumán, en los años previos a la dictadura de Onganía, las dificultades que tenía la industria más importante de la provincia habían provocado un agravamiento de los problemas de empleo. En efecto, hubo una disminución del $28,1 \%$ en el personal de los ingenios entre 1948 y 1966, una caída de 19,1\% en los empleados en el sector cañero en los meses de zafra en el período 1955-1965, y una reducción del empleo permanente en fábricas y surcos, que de representar más del 70\% en 1943, agrupaba en 1966 a menos del $30 \%$ de los obreros de los ingenios ${ }^{37}$.

Entre 1966 y 1968, casi 18.000 trabajadores perdieron su empleo por el cierre de once ingenios tucumanos y la disminución de personal en los dieciséis restantes. A ello se sumaba la caída que hubo en la cantidad trabajadores empleados en tareas de cultivo y cosecha de caña de azúcar: de 96.307 a 64.230 entre 1965 y $1969^{38}$.

Considerando de conjunto los fenómenos señalados, se puede estimar [...] que más de 50.000 personas fueron relegadas de la actividad azucarera. Esta cifra es aún mayor si se tiene en cuenta el declive que se produjo en otras actividades económicas ligadas de manera directa o indirecta a la producción azucarera. (Osatinsky, 2012a, p. 62)

El impacto laboral de la crisis azucarera ocasionó que los sectores agropecuario (primario) y manufacturero de Tucumán perdiesen participación en la composición de la población ocupada provincial (Tabla 12).

En el caso de Catamarca, su sector industrial también sufrió un retroceso en la participación en la estructura de la población ocupada, aunque fue más atenuado que en el caso tucumano. En cuanto al sector primario, adquirió mayor peso en la estructura de empleo provincial. A su vez, el sector terciario incrementó su participación en Catamarca y Tucumán, siendo mayor el incremento que tuvo en esta última. En Catamarca el mayor peso del empleo estatal hacía que en dicha provincia fuese mayor la participación de la construcción y los servicios en la población ocupada.

Tabla 12. Distribución de la población ocupada en Catamarca y Tucumán. 1960 y 1970

\begin{tabular}{|l|c|c|c|c|}
\hline & \multicolumn{2}{|c|}{1960} & \multicolumn{2}{c|}{1970} \\
\hline & Catamarca & Tucumán & Catamarca & Tucumán \\
\hline Primaria & $\mathbf{2 6 , 8}$ & $\mathbf{2 9 , 9}$ & $\mathbf{2 8 , 3 5}$ & $\mathbf{2 4 , 3 4}$ \\
\hline Secundaria & $\mathbf{2 7 , 4}$ & $\mathbf{2 6 , 2}$ & $\mathbf{2 0 , 3}$ & $\mathbf{1 7 , 2 1}$ \\
\hline $\begin{array}{l}\text { Ind manufacturera.; Electricidad, } \\
\text { gas, agua y servicios sanitarios }\end{array}$ & 19,6 & 22,2 & 10,7 & 10,87 \\
\hline
\end{tabular}

36 En el período 1953-1963 la población ocupada en el sector industrial de Catamarca se redujo de 3.708 a 2.664 ocupados (-28,1\%), mientras que en Tucumán esa reducción fue de 34,1\% (de 41.360 a 27.271 ocupados) (Datos de los Censos Nacionales Económicos de 1954 y 1964).

37 Datos de Murmis et al., 1969 y Canitrot et al., 1972, citados en Osatinsky, 2012a, p. 61.

38 Datos de Boneo et al., 1973; Canitrot et al., 1972, citados en Osatinsky, 2012a, p. 61. 
Cuadernos de Trabajo /segunda época /número 5/ Ariel Osatinsky / Pobla-[...] 129

\begin{tabular}{|l|c|c|c|c|}
\hline \hline Construcción & 7,8 & 4 & 9,6 & 6,34 \\
\hline Terciaria & $\mathbf{3 7 , 3}$ & $\mathbf{3 4 , 7}$ & $\mathbf{4 1 , 9 6}$ & $\mathbf{4 1 , 8 5}$ \\
\hline Comercio & 7,6 & 9,9 & 11,4 & 14,16 \\
\hline Transporte, almac. y Comunic. & 4,7 & 6,1 & 4,06 & 5,78 \\
\hline Servicios & 25 & 18,7 & 26,5 & 21,91 \\
\hline Sin especificar & $\mathbf{8 , 5}$ & $\mathbf{9 , 2}$ & $\mathbf{9 , 3 9}$ & $\mathbf{1 0 , 2 1}$ \\
\hline Total & $\mathbf{1 0 0}$ & $\mathbf{1 0 0}$ & $\mathbf{1 0 0}$ & $\mathbf{1 0 0}$ \\
\hline
\end{tabular}

Fuente: Censo Nacional de Población y Viviendas, 1960 y 1970

Los mayores problemas de empleo que sufrió Tucumán también se vieron reflejados en el incremento de la desocupación que tuvo la provincia en el período. En efecto, en 1960 Catamarca tenía el 6,6\% de su población activa desocupada, mientras que en Tucumán ese valor era de 4,1\%. Diez años después, Catamarca tenía una tasa de desocupación de 3,8\%, mientras que esta ascendía en Tucumán a 4,3\% ${ }^{39}$. Probablemente debido a la importante emigración que había sufrido a fines de los '60, la provincia no tenía un mayor desempleo en 1970 . Sin embargo, por primera vez, la población tucumana estaba afectada por una desocupación superior a la de Catamarca.

A partir del año 1967 la desocupación afectó al 10\% o más de la PEA de San miguel de Tucumán, cifras muy elevadas para aquellos años, alcanzando incluso valores superiores en los departamentos provinciales en donde estaban ubicados los ingenios que cerraron (véase Osatinsky, 2012a, pp. 63-64).

Tanto en el plano laboral como en el aspecto demográfico Tucumán tuvo en el período un mayor deterioro. Sin embargo, en el plano social, la situación era más compleja. En efecto, tanto en 1960 como en 1970 Catamarca contó con menores niveles de analfabetismo que Tucumán (véase Tabla 9).

En cuanto a la vivienda, Catamarca tuvo en el período una situación de mayor precariedad, teniendo mayores carencias en cuanto a los materiales y servicios con los que contaban los hogares (véase Tablas 2 y 3 en Anexo Estadístico). Sin embargo, si se compara en la Tabla 2 del Anexo Estadístico los valores que tenían ambas provincias para los indicadores seleccionados en 1960 y 1980, se puede afirmar que la brecha que separaba a Catamarca de Tucumán se fue reduciendo ${ }^{40}$. Pero lo más importante está en la evolución que tuvo la tasa de mortalidad infantil en ambas provincias (Gráficos 1 y 2). Como se observa, la mortalidad infantil en Tucumán en la década del 60 ya no tenía la tendencia declinante de los años previos, sufriendo un incremento importante en la segunda mitad de los '60. Por el contrario, ésta en Catamarca tuvo un descenso mayor que el de Tucumán en aquellos años, alcanzando los valores de su vecina provincia en los últimos ańos de la década.

En los primeros años de la década de 1970 Tucumán volvió a tener una menor tasa de mortalidad que Catamarca, aunque, a diferencia de lo que sucedía en los años 40 y 50, ambas provincias tuvieron entre 1971 y 1975 una reducción con similar tendencia. Sin embargo, en la segunda mitad de los '70, el descenso de la mortalidad infantil fue más pronunciado en Catamarca, teniendo ambas provincias valores casi semejantes a fines de dicha década.

39 Datos del Censo Nacional de Población y Viviendas, 1960 y 1970.

40 Esta reducción fue más notoria en lo relacionado a la tenencia en las viviendas de cañería de agua y retrete con descarga de agua, mientras que fue más lenta en lo que respecta a la electricidad y el piso de tierra, debido al mayor peso que tenían los hogares rurales en Catamarca. 
Por lo expuesto podemos afirmar que Tucumán en los años 50 y comienzos de los '60 tenía todavía una mejor situación social que Catamarca. Sin embargo, en la década siguiente las realidades sociales de ambas provincias tendieron a aproximarse. Catamarca, sin contar todavía a fines de la década de 1970 con mejores condiciones de vida que la de Tucumán, mostraba en los indicadores sociales seleccionados realidades más cercanas que años anteriores. Estás dinámicas cambiantes se explican, en gran medida, por el impacto social ocasionado en la población tucumana por la crisis de la actividad azucarera y el cierre de once de los veintisiete ingenios azucareros entre 1966 y 1968.

\section{Reflexiones finales}

A lo largo del artículo se analizaron cambios demográficos, laborales y en las condiciones de vida de las poblaciones de Catamarca y Tucumán, vinculándolos con las transformaciones económicas.

En la etapa del modelo agroexportador, mientras que Tucumán a través de la producción azucarera logró cierta expansión, Catamarca quedó marginada de la nueva realidad económica, integrando el conjunto de provincias del interior más rezagado. Ello se tradujo en el plano demográfico en un importante crecimiento de la población de Tucumán, mientras que la de Catamarca sufrió un estancamiento. A su vez, el mercado de trabajo tucumano se expandió, sobre todo, por la demanda de trabajo que había en la actividad azucarera. Parte de la población catamarqueña migraba a la zafra azucarera de Tucumán, en busca de un trabajo o de mejores condiciones laborales de las que tenía.

Pese a la mayor dinámica económica y laboral, gran parte de la población tucumana no tenía mejores condiciones de vida que la de Catamarca hasta 1930. Si bien en Catamarca había un mayor porcentaje de viviendas precarias, esta provincia mostraba una mejor situación relativa en comparación con Tucumán en lo que respecta al analfabetismo y la mortalidad infantil. En ese sentido, importa señalar que mientras que el deterioro social que afectaba a la población de Catamarca estaba más ligado con la ausencia de un desarrollo económico, en el caso tucumano la "modernización" que había experimentado la economía, no se había traducido en condiciones dignas de vida para la mayor parte de su población

En las décadas del 30 y 40, Tucumán mantuvo cierto dinamismo económico como consecuencia del desarrollo azucarero. Sin embargo, los problemas que dicha actividad sufrió a partir de 1955, que se agravaron notablemente a fines de los '60 con el cierre de los ingenios, se tradujo en un declive de los sectores económicos más importantes de la provincia hacia fines del período considerado.

Catamarca, por el contrario, mantuvo su economía de característica marginal, con actividades de poca relevancia. Sin embargo, aunque su estructura productiva conservó un prolongado estancamiento, en la segunda etapa de la indsutrialización sustitutiva de importaciones, contó con la expansión de ciertas actividades primarias y terciarias, siendo menos afectada que Tucumán por las transformaciones económicas regresivas.

Debido a las diferentes trayectorias mencionadas, Tucumán, que tuvo hasta 1960 un crecimiento demográfico mayor que Catamarca, sufrió en la década del 60 una pronunciada emigración que ocasionó incluso una reducción absoluta de su población en el lapso 1960-70. Catamarca continuó siendo una provincia de migración neta negativa, aunque a un ritmo más atenuado que en el pasado.

Estos cambios de tendencias también se observaron en el mercado de trabajo de 
Cuadernos de Trabajo /segunda época /número 5/ Ariel Osatinsky / Pobla-[...] 131 ambas provincias. En efecto, mientras que Tucumán mostró en la mayor parte del período analizado una situación laboral menos crítica que Catamarca, fue afectada desde la década de 1950 por crecientes problemas de empleo, llegando en 1970 a tener una desocupación superior a la de su vecina provincia.

Los problemas económicos y laborales de Tucumán impactaron de manera muy regresiva en las condiciones de vida de su población. Por ello, si en la década de 1950 y comienzos de los '60 esta provincia tenía en materia de mortalidad infantil e infraestructura de las viviendas una situación menos crítica que la de Catamarca, a partir de la segunda mitad de la década de 1960, parecía ser Catamarca la que mostraba mayores avances en el plano social. Sin embargo, el hecho de que no hubiese logrado todavía en la década de 1970 alcanzar una realidad social menos crítica que la de Tucumán, reflejaba el profundo deterioro socioeconómico en el que estaban inmersas ambas provincias.

\section{Anexo Estadístico}

Tabla 1. Material de las casas en Catamarca, Tucumán y la Argentina. 1869 y 1895

\begin{tabular}{|l|c|c|c|c|c|c|}
\hline & \multicolumn{2}{|c|}{ Catamarca } & \multicolumn{2}{c|}{ Tucumán } & \multicolumn{2}{c|}{ Argentina } \\
\hline & $\mathbf{1 8 6 9}$ & $\mathbf{1 8 9 5}$ & $\mathbf{1 8 6 9}$ & $\mathbf{1 8 9 5}$ & $\mathbf{1 8 6 9}$ & $\mathbf{1 8 9 5}$ \\
\hline $\begin{array}{l}\text { Casas de piedra o } \\
\text { ladrillo, con techo de } \\
\text { azotea }\end{array}$ & 8,8 & 3,5 & 2,7 & 4,3 & 17,9 & 20,9 \\
\hline $\begin{array}{l}\text { Casa de piedra o } \\
\text { ladrillo con techo de } \\
\text { teja, fierro o zinc }\end{array}$ & 4,4 & 4,6 & 7,5 & 19,8 & 2,9 & 23,2 \\
\hline Casas de Madera & 6,4 & 4,4 & 0,2 & 1,0 & 8,2 & 4,0 \\
\hline Casas de adobe, paja & 80,4 & 87,5 & 89,6 & 73,9 & 71,0 & 49,8 \\
\hline Casas de fierro & & 0,1 & & 1,1 & & 2,1 \\
\hline Total Casas & $\mathbf{1 0 0}$ & $\mathbf{1 0 0}$ & $\mathbf{1 0 0}$ & $\mathbf{1 0 0}$ & $\mathbf{1 0 0}$ & $\mathbf{1 0 0}$ \\
\hline
\end{tabular}

Fuente: Segundo Censo de la República Argentina, Tomo II. 1898.

Tabla 2. Características de la vivienda según indicadores seleccionados. Catamarca, Tucumán y la Argentina. 1960 y 1980

\begin{tabular}{|c|c|c|c|c|c|c|c|c|}
\hline & $\begin{array}{c}\text { \% Viviendas } \\
\text { sin cañería de } \\
\text { agua dentro } \\
\text { de la vivienda }\end{array}$ & $\begin{array}{c}\text { \% Viviendas } \\
\text { sin retrete con } \\
\text { descarga de } \\
\text { agua }\end{array}$ & $\begin{array}{c}\text { \% Viviendas sin } \\
\text { electricidad }\end{array}$ & \multicolumn{2}{|c|}{$\begin{array}{c}\text { \% Viviendas } \\
\text { con piso de } \\
\text { tierra }\end{array}$} \\
\hline & $\mathbf{1 9 6 0}$ & $\mathbf{1 9 8 0}$ & $\mathbf{1 9 6 0}$ & $\mathbf{1 9 8 0}$ & $\mathbf{1 9 6 0}$ & $\mathbf{1 9 8 0}$ & $\mathbf{1 9 6 0}$ & $\mathbf{1 9 8 0}$ \\
\hline Catamarca & 70,1 & 52,5 & 72,4 & 50,1 & 63,8 & 39,7 & 59,4 & 41,9 \\
\hline Tucuman & 64,1 & 50,5 & 66,1 & 46,3 & 52,3 & 27,5 & 37,3 & 22,8 \\
\hline Argentina & 56,5 & 27,1 & 38,5 & 22,9 & 31,2 & 13,2 & 18,1 & 10,2 \\
\hline
\end{tabular}

Fuente: Dirección Nacional de Estadística y Censos, Censo Nacional de Población 1960, Tomos I y II; INDEC (1995), Situación y evolución social, Síntesis No 3, Buenos Aires. 
132/ Perspectivas Metodológicas /20/Vol. II /noviembre, Año 2017

Tabla 3. Viviendas según tipo de material del techo y el piso. Catamarca, Tucumán y la Argentina, 1960

\begin{tabular}{|c|c|c|c|c|c|c|c|}
\hline $\begin{array}{c}\text { Tipo de material } \\
\text { del techo }\end{array}$ & Cat. & Tuc. & Arg. & $\begin{array}{c}\text { Tipo de material } \\
\text { del piso }\end{array}$ & Cat. & Tuc. & Arg. \\
\hline Baldosa & 6,4 & 7 & 16,8 & Mosaico & 21,8 & 31,4 & 28,4 \\
\hline Cubierta asfáltica o similar & 3,8 & 4,8 & 14,3 & Baldosa & 3,9 & 7 & 4,4 \\
\hline Teja & 6,6 & 21,4 & 7,7 & Madera & 0,6 & 1,6 & 32,6 \\
\hline Madera & 2 & 1,1 & 2,7 & Ladrillo & 5,8 & 12,8 & 7,6 \\
\hline Planchas o chapas metálicas & 13,3 & 40,6 & 39,5 & Cemento & 7,6 & 9,1 & 8,5 \\
\hline Cartón prensado o similares & 2,4 & 4,7 & 4,1 & Tierra & 59,4 & 37,3 & 18,1 \\
\hline Pajas y ramas & 28,2 & 15,7 & 7,6 & Otros & 0,9 & 0,8 & 0,5 \\
\hline otros & 37,4 & 4,8 & 7,4 & & & & \\
\hline Total Viviendas & $\mathbf{1 0 0}$ & $\mathbf{1 0 0}$ & $\mathbf{1 0 0}$ & Total Viviendas & $\mathbf{1 0 0}$ & $\mathbf{1 0 0}$ & $\mathbf{1 0 0}$ \\
\hline
\end{tabular}

Fuente: Dirección Nacional de Estadística y Censos, Censo Nacional de Población 1960, Tomos I.

\section{Bibliografía}

— Balán, J. (1976). "Migraciones, mano de obra, y formación de un proletariado rural en Tucumán, Argentina, 1870-1914". Desarrollo y Economía, 10(2), pp. 201-234.

- Bolsi, A. (2000). "La población urbana-rural del Noroeste Argentino en el siglo XX”. En M. Panaia, S. Aparicio y C. Zurita (Coord.). Trabajo y población en el Noroeste Argentino (pp. 41-58). Buenos Aires: La Colmena.

— Bolsi, A. y Pucci, R. (1997). "Evolución y problemas de la agroindustria del azúcar”. En A. Bolsi (Dir.). Problemas agrarios del noroeste argentino (contribuciones para su inventario) (pp. 113-133). San Miguel de Tucumán: Universidad Nacional de Tucumán - Junta de Andalucía.

- Bolsi, A., y Paolasso P. (Comp.) (2009). Geografía de la pobreza en el Norte Grande Argentino. San Miguel de Tucumán: Programa de las Naciones Unidas para el Desarrollo, Universidad Nacional de Tucumán y Consejo Nacional de Investigaciones Científicas y Técnicas.

- Bunge, A. (1917). Riqueza y Renta de la Argentina. Su distribución y su capacidad contributiva. Buenos Aires.

- Ferrer, A. (2008). La economía argentina. Desde sus orígenes hasta principios del siglo XXI. Ciudad de Buenos Aires: Fondo de Cultura Económica.

- Lindenboim, J. (2005). El reparto de la torta. ¿Crecer repartiendo o repartir creciendo? Buenos Aires: Capital Intelectual.

— Lo Vuolo, R., Barbeito, A., Pautassi, L. y Rodríguez, C. (2004). La pobreza... de la política contar la pobreza. Buenos Aires: Ciepp - Miño y Dávila.

- Longhi, F. (2009). Los cambios en la distribución espacial de la pobreza en el territorio del Norte Grande Argentino durante la década de 1990. Una aproximación al proceso a partir de la mortalidad infantil (Tesis de Doctorado).

- Méndez, R. (1997). Geografía Económica. La lógica espacial del capitalismo global. Barcelona: Ariel S. A. 
- Neffa, J. (Coord.) (2005). Actividad, empleo y desempleo: conceptos y definiciones. Capital Federal: Miño y Dávila.

- Ortiz de D’Arterio, J. P. (1997). “Noroeste Argentino. Análisis de los flujos migratorios intra y extrarregionales". En A. Bolsi (Dir.). La población del Noroeste Argentino (contribuciones para su inventario) (pp. 111-123). San Miguel de Tucumán: Instituto de Estudios Geográficos.

- Osatinsky, A. (2001). "Los empresarios azucareros tucumanos frente a las reformas laborales del primer peronismo (1943-1949)". En Actas del 5 Congreso Nacional de Estudios del Trabajo. Asociación Argentina de Especialistas en Estudios del Trabajo.

- Osatinsky, A. (2009). "Pobreza y transformaciones económicas en Catamarca y Tucumán (1980-2002)”. Población y Sociedad, (16), pp.187-222.

- Osatinsky, A. (2012). "El deterioro laboral de las poblaciones de Catamarca y Tucumán (1980-2002)”. Breves Contribuciones del IEG, (23), pp. 86-112.

- Osatinsky, A. (2012a). "Estructura productiva, actividad azucarera y mercado de trabajo en Tucumán (1930-1970)". Revista de Historia Americana y Argentina, (47), pp. 41-71.

- Osatinsky, A. (2013). "La pobreza y su relación con los problemas de empleo en Catamarca y Tucumán (NW Argentina) a fines del siglo XX". Estudios Demográficos y Urbanos, 28 (82), pp. 53-92.

— Osatinsky, A. (2013a). "Las transformaciones económicas regresivas y su impacto desigual en Catamarca y Tucumán (1980-2002)”. ANDES, (24), pp. 367-393.

- Osatinsky, A. (2013b). "Los cambios en la estructura productiva de Catamarca en el siglo XX”. Arena, (2), pp. 1-26.

- Palacios, A. (1938). El dolor argentino. Buenos Aires.

- Palacios, A. (1944). Pueblos Desamparados. Soluciones de los Problemas del noroeste argentino. Buenos Aires: Ed. Guillermo Kraft.

- Parolo, M. P. (2008). Ni súplicas, ni ruegos. Las estrategias de subsistencia de los sectores populares en Tucumán en la primera mitad del siglo XIX. Rosario: Prohistoria ediciones.

- Peláez, A. H. (1998). "Breve reseńa de la evolución de la economía argentina". En J. A. Roccatagliata (Coord.). La Argentina. Geografía general y los marcos regionales. Buenos Aires: Planeta.

- Rapoport, M. (2000). Historia económica, política y social de la Argentina (18802000). Buenos Aires: Macchi.

— Rofman A. B. y Romero, L. A. (1997). Sistema socioeconómico y estructura regional en la Argentina. Buenos Aires: Amorrortu editores.

- Santamaría, D. (1985). "Estado, industria azucarera y conflicto social en Tucumán durante el segundo gobierno radical (1922-1928)”. Revista de Indias, 45(175), pp. 161-180.

- Santillán de Andres, S. E. (1969). Esquema de la estructura socio-económica de la Provincia de Tucumán. San Miguel de Tucumán: Departamento de Geografía de la Facultad de Filosofía y Letras de la UNT. 



\section{Reseñas}



Reseñas / 137

PHILIP KITCHER, Avance de la Ciencia. Ciencia sin ley, Objetividad sin Ilusiones. México, UNAM, $2001^{1}$

Philip, K. (2001) Avance de la Ciencia. Ciencia sin ley, Objetividad sin Ilusiones,
UNAM: México D.F.
¿Cómo hacen realmente ciencia los científicos? El filósofo ingles Philip Kitcher (1947) se ocupa de pensar el quehacer científico analizando, a lo largo de 8 capítulos y un Post Scriptum, cómo se constituyen los procesos de formación de investigadores, las relaciones entre autoridades y alumnos, el modelo de mente que se conjetura como parte del sistema de pensamiento del razonamiento científico, los criterios ontológicos y epistémicos que entran en juego en las variaciones cognitivas de las micro-comunidades científicas en breves periodos de tiempo (6 meses aproximadamente), la influencia de las amistades y las conversaciones de pasillo para delinear los proyectos de investigación, como también la relación implícita -y necesaria- entre la financiación de las instituciones científicas hacia ciertos proyectos de investigación y la propuesta de cuál es la ciencia que un sector y/o región debería desarrollar.

Según este epistemólogo, su propuesta es un punto intermedio entre el racionalismo de Kuhn y el irracionalismo de Feyerabend, los investigadores eligen libre y racionalmente con quién/es unirse para maximizar sus avances en el conocimiento (metas epistémicas) y cumplir sus objetivos personales (metas no epistémicas) pero, el consenso de las prácticas junto con la definición del progreso científico, se determina, por un lado, a partir de un supuesto de realismo fuerte, y por otro lado, cuando un número suficiente de sub-grupos, lo bastante poderosos en el interior de la comunidad (autoridades y colegas), han tomado la decisión de modificar sus prácticas de forma particular (sea la resolución tomada de forma independiente o coordinada).

El interés epistémico de P. Kitcher es pensar a las prácticas de los científicos desde lo que se reconoce como el "Giro Naturalista", en donde se considera que el humano es un fenómeno natural, por lo que sería válido su estudio epistémico desde las ciencias.

En primer lugar, las ciencias se comprenden como un proceso en el que "[...] entidades cognitivamente limitadas combinan esfuerzos en un contexto social” (p. 22), para configurar modelos teóricos que se ajusten a la realidad según la preocupación de los usuarios.

La ciencia utiliza sus "modelos teóricos de conocimiento del mundo" como mapas cognitivos (p. 555), i. e., poseen un objeto estándar (ubicación geográfica) pero los diagramas y caracteres que lo representan son establecidos por los "usuarios" (investigadores) y sus "preocupaciones" (metas epistémicas y no epistémicas). Al igual que distintos "mapas" pueden mostrar distintos aspectos de un mismo territorio, los distintos "modelos teóricos" pueden mostrar distintos aspectos de un mismo sistema de la realidad. En principio, no habría "incongruencia entre distintos modelos teóricos" (p. 560) porque se enfocan en diversos aspectos del mismo sistema, al menos que se haya creado un "modelo teórico" que afirme representar todos los aspectos de un mismo sistema.

En consecuencia, existe un pluralismo modesto, en donde cada teoría responde a sus

1 Si bien las reseñas de libros que se publican en Perspectivas Metodológicas hacen referencia a textos que no tienen más de tres o cuatro años de antigüedad, hemos realizado una excepción con esta reseña del texto de Philip Kitcher, que fue publicado en 2001. No es un autor muy divulgado en nuestro medio y nos parece que sus enfoques pueden ser un aporte para los debates epistemológicos que se vienen dando en nuestra región. Agradecemos por lo tanto a los autores de la reseña por este envío. 
intereses, los cuales forman a su contexto, pero comprendiendo que la teoría puede ser reestructurada (ajustada) en cualquier momento, v. gr., sus intereses pueden modificarse o puede modificarse el sistema de realidad en el que se ocupa. Este "pluralismo modesto" de Kitcher está inspirado en la tesis de N. Cartwright titulada "pluralismo metafísico nomológico", en donde la naturaleza es gobernada por diferentes sistemas de leyes en diferentes dominios.

En segundo lugar, las prácticas científicas individuales están orientadas por un conjunto de "metas" que tiene en cuenta el sujeto cognoscente, éstas se dividen en personales e impersonales. Los investigadores eligen libre y racionalmente con quién/es unirse para maximizar sus avances en el conocimiento y cumplir sus objetivos personales (p. 111).

Este supuesto que parte de la doble idea de que se comparte una geografía cognitiva (p. 102) y existen metas epistemológicas impersonales compartidas (p. 135), se refuerza con un refinamiento realizado por Kitcher sobre el "principio de humanidad" de R. Grandy, en donde se supone que los interlocutores poseen mayormente un equipo cognitivo similar al nuestro (p. 146). En este punto, Kitcher también reconoce su deuda en de las ideas de S.T. Mill sobre libertad y racionalidad, pero argumenta que el debate central de la libertad yace en cuáles son los valores importantes que se deben defender.

El debate de los valores comprende tanto los esfuerzos de los investigadores por alcanzar sus metas (epistémicas y no epistémicas) como el modo de significar las verdades que se obtienen en la creación de los mapas cognitivos.

Los investigadores que buscan combinar esfuerzos, asumen que hay fines o metas últimas y epistémicas que definen sus propias prácticas científicas, las cuales son dirigidas por la interpretación que hacen las autoridades de las pequeñas comunidades científicas, especificadas por un campo particular de investigación y de trabajo. "Unificar nuestra explicación del mundo es para nosotros un desiderátum cognitivo” (p. 242)

La "verdad científica significativa" se establece como aquel objetivo de responder a las preguntas científicas con sentido o preguntas científicas significativas, estas son, aquellas cuestiones o interrogantes que dan cuenta y comprenden una teoría de forma completa, y suponen, primero, concepciones de referencia exitosa, segundo, potenciales de referencia adecuados (modos de referencia a un término de la teoría), tercero, esquemas explicativos correctos, cuarto, enunciados verdaderos, y quinto, enunciados falsos mejorados (p. 228).

La "verdad científica significante" (p. 170) será, entonces, aquel conocimiento que aumentará la posibilidad de alcanzar las metas prácticas ya propuestas por la pequeña comunidad científica, o por las autoridad/es de la comunidad, o por la institución a la que pertenecen los investigadores.

La conclusión a la que arriba P. Kitcher converge una caracterización del progreso científico con la preocupación de la democratización del conocimiento, en donde la formación de un consenso sobre una verdad científica significativa conjugaría las diversas metas de los participantes de la comunidad científica.

Su propuesta comprende que sólo a través de la reflexión de que el conocimiento científico es el resultado de una compleja historia que involucra una multitud de actores y circunstancias, es posible obtener una visión sintética de las circunstancias a las que responden y se enfrentan las estructuras, roles, instituciones y normativas, las cuales deben orientar constantemente sus investigaciones a la conjunción de lo verdadero y lo apropiado. 
Reseñas / 139

MARÍA GABRIELA PAULI, "La Cabeza piensa y ordena y los brazos ejecutan...". Representaciones sociales de la élite santafesina a comienzos del siglo XX, Universidad Católica de Santa Fe, Santa Fe, 2017

Estudiar a las élites argentinas, su historia, sus prácticas sociales, su constitución es una de las tantas tareas pendientes de los historiadores argentinos. Probablemente, la vigencia actual de estas élites en el escenario político, cultural y académico, pueden explicar algunas razones de este derrotero. Lo cierto es que el libro de Gabriela Pauli significa un aporte fundamental para la comprensión en profundidad de la élite santafecina en sus formas de representación social, los alcances de su legitimidad en relación a los otros sectores sociales como los modos de ejercer el poder en la ciudad hacía principios del siglo XX.

El libro además es un minucioso estudio. Se asienta sobre una investigación desarrollada en el marco de una tesis doctoral de Historia, por ello es un trabajo preciso y estrictamente delimitado a la ciudad de Santa Fe en los primeros años del siglo XX. Preciso, porque se abordan principalmente dos fuentes gráficas, dos periódicos de Santa Fe. Delimitado, porque se analiza, con datos estadísticos y de archivo, las transformaciones que se producen en materia socioeconómica en la ciudad entre fines del siglo XIX y 1905.

A pesar de estos rasgos, no ocurre aquello que ocurre generalmente con los libros escritos por historiadores. El lector no se encuentra con una investigación de historia sino con un libro que se apoya en una investigación de historia. En consecuencia, su lectura resulta doblemente atractiva.

Gabriela Pauli, comienza con una introducción en donde explica algunas cuestiones vinculadas al estudio de fuentes gráficas. En este apartado, rápidamente indica al lector que ha trabajado las fuentes historiográficas desde la perspectiva del Análisis Crítico del Discurso. Nos señala por un lado, sobre las características propias del estudio de los discursos, la crítica inmanente, la persuasión o manipulación. Nos habla sobre los problemas de una lectura ingenua de los medios gráficos. En el caso de los periódicos santafesinos estudiados: Nueva época y Unión provincial, nos explica que surgieron desde las necesidades de la política provincial. Ambos diarios, fueron instrumentos decisivos para la élite de la ciudad, desde sus páginas se imponían candidaturas, se marcaba el tono social y se establecían pautas morales en orden al buen vivir.

A la introducción le sigue dos capítulos en donde rápidamente se orienta al lector sobre el contexto histórico a nivel general nacional y a nivel particular, en la provincia de Santa Fe.

Se focaliza principalmente en las transformaciones en el ejercicio del poder desencadenadas a partir de los cambios políticos, económicos y sociales. Pauli se refiere a la consolidación del Estado manifestada a través del avance del poder de sus instituciones, educativas y municipales, y su consecuente tendencia a la centralización política frente a los resabios de aquellos pronunciamientos federales del siglo XIX, como al poder ejercido por la autoridad de la Iglesia Católica sobre la sociedad civil desde los tiempos de la colonia. Además, destaca el tema de las colonias agrícolas santafesinas, observando la relación entre inmigración, producción de tipo familiar y la promoción por parte del Estado de estas colonias para la ocupación del territorio en dominio de las comunidades nativas. Finalmente esta primera parte del libro, se detiene en estudiar los efectos del proceso inmigratorio en las prácticas sociales. 
Hasta aquí, podríamos decir que Pauli prepara al lector para lo que sigue. En la segunda parte, apoyándose en las publicaciones periódicas, Pauli nos introduce en su minucioso estudio sobre las prácticas sociales de la élite santafesina. Sobre las diferentes imágenes que se construían de ellos mismos como de los otros sectores de la sociedad. Intercalando la transcripción de los textos con el análisis de los mismos, Pauli logra que el lector se inserte en la parte más sustanciosa de su investigación. Por ejemplo, expone los diferentes indicadores del imaginario social de la élite, como son los adjetivos con los cuales caracterizaban en estos periódicos a los referentes del grupo: digno representante, de numerosísimas relaciones, distinguido viajero, con incontables amigos; los textos de los avisos fúnebres o los discursos sobre los eventos en donde se hacía entrega de diplomas y menciones de honor.

El sus últimos capítulos, Pauli resuelve con una serie de puntos ciegos vinculados a los estudios anteriores sobre el periodo. Lejos de encontrar enfrentamientos entre las concepciones conservadoras y liberales, positivistas y católicas, en el libro se demuestra como todos estos componentes pueden condensarse dentro de la predilección de la élite santafesina por la práctica de una República restringida, muy a pesar de sus signos de agotamiento.

FACUNDO DI VINCENZO 
Reseñas / 141

JEAN YVES MOLLIER, La Lectura y sus públicos en la edad contemporánea, Buenos Aires, Ampersand, 2013

El libro de Jean Yves Mollier se inscribe en una tradición de larga data en la historia de las ciencias sociales europeas.

En esta tradición, fundada en 1929 por los historiadores franceses March Bloch (1886-1944) y Lucien Febvre (1878-1956), la labor central del historiador, el análisis de fuentes historiográficas, se desarrolla a partir del cruce con enfoques extraídos de otras disciplinas de las ciencias sociales como pueden ser la antropología, la filosofía o la literatura. Con estos cruces, Bloch y Febvre, inauguraban nuevas formas de aproximación a la historia de las sociedades humanas.

Dentro de esta escuela historiográfica, llamada luego como de los Annales, hay dos campos de estudio que han evolucionado en forma notable en los últimos cincuenta años. El primero relacionado con "la historia de las mentalidades" y el segundo con "la historia cultural". Atravesado por estos dos campos, el cultural y el de las mentalidades, Jean Yves Mollier desarrolla su libro La Lectura y sus públicos en la edad contemporánea.

En la introducción a la primera edición, el autor nos advierte que contiene nueve ensayos divididos en cuatro partes. Todos referidos a la lectura y sus públicos desde mediados del siglo XVIII hasta comienzos del siglo XX.

La advertencia, que claramente intenta justificar la autonomía entre cada uno de los textos que integran el libro, aunque válida, pasa de inadvertida para el lector.

Estos ensayos no sólo interactúan de una manera dinámica y ágil, sino que también permiten la posibilidad de abordarlos en conjunto o en forma individual, ya que si bien cada uno de ellos tiene una coherencia y un objeto de estudio particular, al mismo tiempo, mantienen un lazo directo con el objeto central del libro: La lectura y sus públicos durante la edad contemporánea.

Mollier comienza con un minucioso recorrido por los primeros editores, sus selecciones de autores y primeras formas de edición, la relación entre estos y los autores, sus formas de difusión y circulación. Luego el autor, nos introduce en la relación que existía entre el producto terminado: El libro, y quienes lo consumen: Sus lectores. En este parte, Mollier nos inserta en su quimérica investigación, en donde uno de sus objetivos es explicar el origen y el funcionamiento de la literatura popular.

A partir del ensayo titulado: “¿Literatura industrial o literatura popular?”, el autor se interna en un laberinto de actores que accionan en simultáneo sobre las ediciones de la época.

Se suceden los libreros, lectores, mercados, autores, y sus espacios de circulación: escuelas, bibliotecas, iglesias y demás. Mollier sumerge al lector en el movimiento que generan los vaivenes de la demanda de estos libros, en donde los editores deben tomar decisiones rápidamente. Decisiones efectivas, como seleccionar autores que aumenten las ventas y a la vez que reduzcan los gastos y la competencia con otras casas editoras. La elección de autores como Gustave Flaubert (1821-1880), Alexandre Dumas (18021870) o Alphonse Lamartine (1790-1869) en paralelo a la reducción de hojas y de formatos o la posibilidad de fraccionar las entregas en varios volúmenes, son mecanismos que eligen los editores como Michel Levy (1821-1875) o Pierre Jules Hetzel (18141886), para reducir los costos y aumentar las ganancias.

En este punto, Mollier enlaza las dos tradiciones en la que se inscribe su estudio: "la historia de las mentalidades" y "la historia cultural". Relata la forma en que los lectores 
comienzan a elegir hacía 1836 a la novela-folletín introducida por la prensa barata en la planta baja del periódico. Destaca el ingenio popular desarrollado en la población urbana más carenciada a la hora de conservar estos folletines, en donde las mujeres con una gruesa aguja y un hilo resistente confeccionaban extraños libros que con el tiempo se convertían en auténticas "bibliotecas caseras". Estos usos no previstos, que se conectan con prácticas rurales de antaño, terminan desbaratando los cálculos de los editores que vivían en el corazón de las ciudades, desmembrando las estrategias que habían significado su éxito.

En el ensayo titulado: "La inhallable biblioteca del pueblo", el autor se dedica al estudio de los manuales escolares y de las bibliotecas bajo la coyuntura de la explosión de la escolarización en Europa (1850 y 1900). Mollier con una exhaustiva investigación sobre los diferentes tipos de manuales y sus ventas demuestra la revolución cultural que produce el encuentro entre el libro y las grandes masas de población antes analfabetas.

En la tercer parte, titulada: "El folletín en la prensa y en la librería francesa del siglo XIX”, el autor vuelve a ocuparse del folletín. Su origen, formas y lectores. Señala la trascendental influencia que tuvo para el florecimiento de las nuevas prácticas culturales que impulsaron la construcción de identidades cada vez más parecidas, al masificar los comportamientos de la sociedad.

En la cuarta parte y a modo de epilogo, Mollier se dedica a estudiar una serie de cuestiones que derriban los supuestos establecidos en torno al origen de una literatura popular en Europa. Demuestra que las formas de los productos culturales: aquellas formas vinculadas a "la historia cultural" son indisociables de las prácticas o acciones sociales relacionadas con "la historia de las mentalidades".

FACUNDO DI VINCENZO 
CRISTINA CAMPAGNA, MÓNICA GIARDINA, OSCAR CUERVO, EDUARDO LASO, Para pensar la ciencia y la técnica. Una introducción a la tecnociencia, Buenos Aires, Editorial FEDUN, 2017

En los libros dedicados a temas de Epistemología y Metodología, sobre todo los que están dedicados a cursos de iniciación en estas disciplinas, es común advertir que hay varias deficiencias cuando se presentan temas de Metodología sin sustento epistemológico o se presentan los autores emblemáticos de la Epistemología sin tratar las derivaciones de sus ideas en el campo de la Ética o la Política. Algunas propuestas son logicistas y aparecen como sucedáneas del clásico manual de Irving Copi, de Introducción a la lógica, o son decididamente una secuela del manual de Introducción a la filosofía de Adolfo Carpio. En los inicios del Ciclo Básico Común de la Universidad de Buenos Aires, en marzo de 1985, la materia Introducción al Pensamiento Científico, una de las dos obligatorias junto a Introducción al conocimiento de la Sociedad y el Estado, requirió la formación de una gran masa de docentes. Las distintas cátedras orientaron sus programas, sobre la base de unos contenidos mínimos, pero entre sí mostraban una gran dispersión de intereses. En esos manuales era frecuente encontrar la Historia de la ciencia contada como el logro de algunas mentes más brillantes que otras mientras que los temas canónicos de la Filosofía de la ciencia aparecían desgajados de las contextualizaciones históricas. Ante tal estado de cosas aparece como necesario recordar la conocida sentencia de Lakatos que remeda la de Kant:

La filosofía de la ciencia sin historia de la ciencia es vacía, la historia de la ciencia sin filosofía de la ciencia es ciega (Lakatos, 1987) LAKATOS I : La historia de la ciencia y sus reconstrucciones racionales. Madrid, Tecnos, 1987 p.11.

El libro del que nos ocupamos en esta reseña evade estas limitaciones ya que se presenta como una propuesta de epistemología crítica pero sienta las bases filosóficas para mostrar en los orígenes de la filosofía griega esta actitud de la que espera ser consecuente en su propuesta. El ordenamiento de los artículos evidencia esta postura rupturista respecto a la posición canónica acerca de la neutralidad y la objetividad científica. Los autores, expertos profesores en el dictado de la materia Introducción al pensamiento científico del Ciclo Básico Común de la UBA, ordenan en esta secuencia de artículos una propuesta completa y exhaustiva de presentación crítica de los supuestos epistemológicos del positivismo y del neopositivismo, a la vez que desarrollan los principales argumentos de pensadores de rara aparición en este tipo de manuales como, Friedrich Nietzsche, Karl Marx, Martin Heidegger, Gastón Bachelard, Alexandre Koyré, Louis Althusser, Michel Foucault, Illya Prigogine, Enrique Mari y Oscar Varsavsky.

La secuencia de artículos evidencia la propuesta didáctica ya que podemos ver la especial preocupación por fundamentar el concepto de "tecnociencia", de fuerte carga crítica respecto a la imagen positivista de la ciencia como un saber autonomizado del resto de las actividades sociales en vista a los requerimientos de objetividad y neutralidad. En El saber y la filosofía de Oscar Cuervo, se pregunta ¿qué es saber? Cuestiona la distinción entre saber teórico y práctico sin decirlo en términos técnicos y con ello abre la puerta a una toma de distancia con el cientificismo. La fusión entre la actitud filosófica y actitud política tiene como ejemplo el de Sócrates aludiendo a la presentación de Platón en Apología de Sócrates. Con la presentación de Descartes abre la puerta a la filosofía de la subjetividad moderna antes de exponer en el artículo siguiente las principales notas del Positivismo. En Ciencia y epistemología Oscar Cuervo se pregunta 
¿qué son las ciencias? Ahora revisa el criterio de demarcación entre ciencia y no ciencia mostrando los argumentos de rechazo a la actitud monista para presentar los caracteres de la actitud cientificista. Realiza una presentación del positivismo a través de los tres estadíos enunciados por Augusto Comte. Presenta una crítica al cientificismo como actitud hegemónica que ha logrado asentar la distinción entre ciencia pura, ciencia aplicada y tecnología. Para contrarrestar la inercia de esta posición tradicional propone recuperar el plural para hablar de Ciencias como paso necesario de una epistemología crítica, una epistemología ampliada a la consideración de las condiciones socio históricas en las que se producen las ciencias y a los particulares marcos metodológicos en cada una de ellas. Luego de este posicionamiento epistemológico encontramos dos artículos dedicados a la revisión histórica de las matemáticas en un artículo de Cristina Campagna El saber matemático: un recorrido histórico donde se presenta el período pregriego, pre euclideo y Euclides, las geometrías neoeuclideanas y una conclusión sobre el estado actual. Luego otro artículo de vertiente histórica sobre La revolución copernicana: un nuevo modelo de saber de Oscar Cuervo quien profundiza en la necesidad de contextualizar los logros de la modernidad en el campo de las ciencias. En este artículo se revisa la Historia de la física a partir de la presentación del llamado "giro copernicano". El autor presenta el giro copernicano como innovación y luego como Revolución científica en términos de Kuhn a partir de "El caso Galileo", ejemplo paradigmático ya tomado por Thomas Kuhn como caso de interés epistemológico para mostrar las complejidades del cambio de paradigma. El artículo de Mónica Giardina Del "mundo del aproximadamente" hacia el "universo de la precisión". La impronta matemática en la física de Galileo profundiza la presentación de los artículos anteriores de Cuervo y Campagna. Giardina presenta el caso del principio de inercia como un intento de modelización matemática. El experimento de la torre de Pisa sirve como ejemplo, en favor de la posición de Thomas Kuhn, para mostrar que viendo lo mismo los aristotélicos y los galileanos interpretaron cosas distintas. La idea que se presenta, en contra de la noción tradicional de objetividad, es que los hechos toman sentido a la luz de un marco teórico en relación con otros hechos. Aquí se expresa el ideal de reducir los fenómenos a esquemas matemáticos, ideal que marca las posiciones de Descartes, Galileo y Bacon.

Luego de este bloque de artículos de posicionamiento histórico y epistemológico se presentan los siguientes artículos escritos por Eduardo Laso dedicados a temas de Metodología y Lógica. El titulado Lógicas formales de la investigación científica: los métodos resulta central para un curso de Introducción al pensamiento científico ya que avanza en el terreno del pensamiento formal sobre la base de la presentación anterior de la historia de la filosofía, de la matemática y de la física. Se exponen los distintos métodos, en primer lugar el método inductivo y las críticas de Hume. La presentación del método deductivo alude especialmente a la formulación del Método Hipotético Deductivo tal como lo presenta Carl Hempel. A partir de esta exposición se refiere el autor a los criterios de demarcación verificacionista y falsacionista. Cierra el artículo con las críticas al falsacionismo. El siguiente artículo Paradigmas y revoluciones científicas del mismo autor presenta el debate formalismo vs historicismo. Presenta las características de la llamada "Concepción Heredada" y sus autores emblemáticos como representantes del formalismo. Para la presentación del historicismo señala la importancia de la aparición en 1962 del libro La estructura de las revoluciones científicas de Kuhn. Aquí se presentan los conceptos emblemáticos de este autor como los de "comunidad científica", "ciencia normal", "revolución científica", "progreso científico", "inconmensurabilidad". Como un aporte importante en 
estos temas se señala también la crítica de Enrique Marí quien destaca que Kuhn mira solamente la historia interna de la ciencia, las comunidades científicas y deja afuera los factores económicos y políticos. El última artículo de Laso, Una introducción a la epistemología de las ciencias sociales presenta la figura emblemática del positivismo, Augusto Comte, como un pensador preocupado en la necesidad de ordenar y hacer gobernable el cuerpo social, necesidad del desarrollo capitalista a finales del S XVIII y principios del XX. Aquí se evidencia el aporte de la filosofía de Michel Foucault en sus análisis de la llamada "sociedad disciplinaria". Laso revisa los tres paradigmas en ciencias sociales: el Positivismo, la Hermenéutica y la Ciencia social crítica: el materialismo histórico. Para caracterizar a este paradigma de alto impacto en el pensamiento contemporáneo revisa los conceptos presentes en la obra de Karl Marx de praxis, estructura y superestructura, conflicto social y lucha de clases, ideología, método dialéctico.

Finalmente, un último bloque de artículos está dedicado a presentar el problema de la técnica y a fundamentar el uso del término "tecnociencia”. En La cuestión de la técnica Mónica Giardina alude a la imagen del fuego y la técnica: Prometeo y Hefesto. Presenta la autora las diferencias conceptuales entre técnica, tecnología, tecnocracia, tecnociencia. Luego señala el vínculo entre tecnología y economía. Expone las posiciones de José Ortega y Gasset y de Martin Heidegger para cuestionar el problema de la neutralidad tecnocientífica. En el artículo siguiente Casos para pensar los contenidos previos Mónica Giardina revela una perspectiva heideggeriana, en la aplicación de las ideas del artículo anterior a situaciones que muestran la intervención de la tecnociencia en la sociedad. En "La pelota maldita" alude a la intervención de la ciencia en el diseńo de la pelota del Mundial. En "La rosa azul” señala la intervención de la ingeniería genética cuando produce formas inéditas en la naturaleza. Fukushima, el embotellamiento chino y la selfie es un camino de ida son apartados de este capítulo que suponemos serán de gran fertilidad para mostrar la presencia de la tecnociencia en nuestra sociedad. El artículo de la misma autora, La ecología en el horizonte contemporáneo recupera el origen del término "ecología” en Ernst Haeckel. Giardina alude a este marco teórico como un nuevo paradigma para pensar la vida. Los últimos tres artículos definen la posición de inicio: necesidad de repensar el lugar de la producción científica en la sociedad, crítica a la neutralidad de la ciencia, crítica al pensamiento hegemónico, crítica a las dicotomías entre razón teórica y práctica, actitud cientificista. La ética y la responsabilidad social en la investigación de Cristina Campagna expone una crítica al positivismo en los supuestos de objetividad y neutralidad. La autora señala un punto de quiebre en las imágenes optimistas de la ciencia luego de las consecuencias de la Segunda Guerra Mundial, en el juicio de Nuremberg y en la sanción del Código por parte de Las Naciones Unidas. Así se señala la necesidad de formación ética en los profesionales que no se restringa al conocimiento de las normas. En Ciencia, politica y economía Campagna alude a las posiciones de Amartya Sen, Oscar Varsavsky, Enrique Dussel antes de la presentación de organismos regionales de biotecnología que atienden a los aspectos bioéticos de la producción científica. Cierra este libro el artículo La Universidad como escuela de ciudadanía donde Campagna presenta las limitaciones actuales de las Universidades Nacionales frente a los nuevos desafíos y plantea un ideal hacia el que orientar las acciones "debe ser elástica, permeable, ética, intercultural. Acompañará los cambios sociales o quedará fuera de la contienda que los pueblos están protagonizando”.

Para concluir esta presentación destacamos los méritos de esta presentación de temas: resisten la tentación de la cita bibliográfica lo que es muy difícil para quienes nos forma- 
mos en la escritura académica. Este estilo evidencia seguridad y manejo en profundidad del tratamiento de los autores involucrados. El estilo de escritura también evidencia capacidad de síntesis y de allanamiento del tecnicismo filosófico. Un libro introductorio es el primero que se lee y el último que se escribe. Este libro es un concentrado de ideas, expuestas con criterio didáctico y evidencia la experiencia tomada en las aulas junto al conocimiento en profundidad producto de la producción de escritos académicos acreditados en publicaciones anteriores. En definitiva este libro evade las limitaciones ya mencionadas y muestra una propuesta sólida y completa para iniciar la vida universitaria en esta sociedad tecnocientífica que transitamos y en vista a cumplirse los 100 años de la Reforma Universitaria de 1918.

CECILIA POURRIEUX 
